\title{
Elias
}

Grahame Applegate Kuswata Kartawinata

Machfudh

Art Klassen

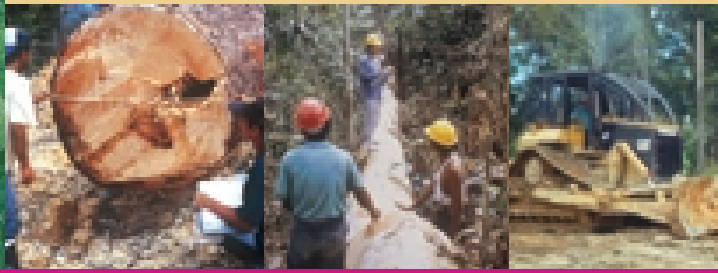

Pedomanan Reduced impact logging Indonessia
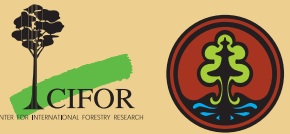

$\frac{\text { THE JOHN D. AND CATHERINE T. }}{\text { MACARTHUR FOUNDATION }}$

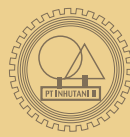

ITTO 


\section{PEDOMAN REDUCED IMPACT LOGGING INDONESIA}

Elias

Grahame Applegate

Kuswata Kartawinata

Machfudh

Art Klassen 
Ucapan terima kasih atas bantuan dana disampaikan kepada International Tropical Timber Organization (ITTO) melalui Project PD 12/97 Rev.1 (F), Forest, Science and Sustainability: the Bulungan Model Forest, CIFOR dan MacArthur Foundation

Foto Sampul oleh Kuswata Kartawinata, Herwasono Soedjito, Plinio Sist dan Hari Priyadi

Ilustrasi dan Tim produksi:

Roup Purohim dan Eko Prianto, Gideon Suharyanto, Widya Prajanthi

\section{ISBN 979-8764-75-7}

() 2001 oleh Center for International Forestry Research Hak Cipta Dilindungi Undang-undang

Diterbitkan Tahun 2001

Dicetak oleh SMK Grafika Desa Putera, Indonesia

Diterbitkan oleh

Center for International Forestry Research (Cifor)

Alamat Surat: P.o. box 6596 Jkpwb, Jakarta 10065, Indonesia Alamat Kantor: Jl. cifor, Situ Gede, Sindang Barang,

Bogor Barat 16680, Indonesia

Tel.: +62(251)622622; Fax: +62 (251) 622100

E-mail: cifor@cgiar.org

Web Site: Http://www.cifor.cgiar.org 


\section{PRAKATA}

\section{Ir. A. Fattah DS.}

Kepala

Badan Penelitian dan Pengembangan Kehutanan

Departemen Kehutanan

Pertama-tama saya menyambut gembira dengan diterbitkannya buku PEDOMAN REDUCED IMPACT LOGGING INDONESIA ini, yang merupakan hasil karya nyata yang telah lama ditunggu oleh para praktisi logging di Indonesia. Buku pedoman ini disusun sebagai pegangan dalam melaksanakan penebangan hutan di Indonesia yang berwawasan lingkungan yang merupakan bagian dari upaya untuk mewujudkan pengelolaan hutan secara lestari.

Untuk memenuhi kebutuhan pengguna, bahasa yang digunakan dalam buku ini dipilih yang mudah dimengerti dan difahami, sedangkan formatnya dibuat sedemikian rupa sehingga mudah dan praktis untuk dibawa ke lapangan.

Pada kesempatan ini, saya mengucapkan terima kasih kepada ITTO yang telah memberikan dana untuk terlaksananya kegiatan penelitian Reduced Impact Logging (RIL) sebagai dasar penyusunan buku pedoman ini. Secara khusus saya juga mengucapkan terima kasih kepada CIFOR yang telah bersama-sama dengan Badan Litbang Kehutanan berhasil menyelesaikan proyek dengan baik, dan kepada PT Inhutani II, yang telah bekerjasama dalam pelaksanaan penelitian RIL ini, serta kepada semua pihak yang telah membantu tersusunnya buku ini. 
Akhirnya, semoga buku "PEDOMAN REDUCED IMPACT LOGGING INDONESIA' ini dapat mencapai tujuan dan sasaran yang tepat, dan bermanfaat bagi keberhasilan pengelolaan hutan yang lestari.

Desember 2001 


\section{PRAKATA}

\section{Dr. Mafa Chipeta}

Deputi Direktur Jenderal

CIFOR

Masyarakat dunia telah menyatakan diri untuk mencapai suatu pengelolaan hutan yang lestari, yaitu pengelolaan yang menyeimbangkan tujuan-tujuan produksi dengan tujuan lingkungan dan sosial. Dalam dunia pemanenan hutan, pencapaian pengelolaan hutan yang lestari memerlukan suatu kegiatan yang bertanggung jawab secara lingkungan. Dari sinilah muncul ketertarikan terhadap Pembalakan Berdampak Rendah atau Reduced Impact Logging (RIL). Center for International ForestryResearch (CIFOR) telah merasakan keberuntungannya dengan adanya bantuan dana dariInternational Tropical Timber Organization (ITTO) serta kerjasama yang erat dengan Badan Litbang Kehutanan Republik Indonesia, untuk melaksanakan penelitian praktis dibidang RIL di hutan hujan tropika di Kalimantan, Indonesia. Berbeda dengan penelitian umum yang biasanya berbasis pada petak percontohan, penelitian CIFOR ini dilaksanakan dalam skala komersial di wilayah konsesi PT Inhutani II, suatu Badan Usaha Logging Milik Negara.

Inti dari pengadopsian hasil penelitian $\mathrm{RIL}$ yang cukup sukses ini adalah satu set buku panduan yang jelas, yang menerangkan kegiatan-kegiatan apa saja yang diperlukan guna mencapai pengelolaan hutan yang lestari. Buku panduan ini, yang diadopsi oleh proyek, sesuai dengan peraturan TPTI suatu sistem silvikultur di Indonesia untuk hutan alam tanah 
kering. Buku panduan ini juga selaras dengan ITTO Guidelines untuk pengelolaan hutan alam tropika secara lestari serta sesuai juga dengan the FAO Model Code untuk praktek-praktek pemanenan hutan.

Dalam penyiapan buku pedoman ini, CIFOR telah termotivasi dengan format buku ini yang sederhana, mudah dipahami, praktis, serta mudah dibawa ke mana-mana. Dengan format seperti ini, para operator di lapangan cukup senang untuk menerapkannya. Telah banyak peraturan-peraturan dan petunjuk-petunjuk tehnis tentang bagaimana memanen hutan secara lestari, tetapi sedikit dari peraturan dan pedoman tersebut yang mempunyai format yang mudah dipahami serta sederhana penyampaiannya. Dalam merekomendasikan penggunaan buku pedoman ini ke perusahaan, CIFOR juga mengundang para praktisi di lapangan untuk memberikan masukan balik tentang bagaimana kebaikan penerapan pedoman ini di lapangan sehingga dapat dilakukan perbaikan-perbaikan secara kontinyu. CIFOR menyatakan diri untuk terus melanjutkan kerjanya ke arah penyempurnaan praktik-praktik $\mathrm{RIL}$ secara progresif melalui kerjasama dengan pemerintah Republik Indonesia, perusahaan perkayuan dan pihak-pihak lain yang tertarik dengan kegiatan pembalakan yang bertanggung jawab.

Dengan terbitnya buku padoman ini, sebagai salah satu keberhasilan proyek yang penting, saya memanfaatkan kesempatan ini, sebagai wakil dari CIFOR, untuk menyatakan terima kasih kepada ITTO yang telah mendanai proyek ini, kepada PT Inhutani II atas kolaborasinya dalam pelaksanaan penelitian dan pengetesan tehnik RIL ini di lapangan, serta kepada Badan Litbang Kehutanan yang telah secara bersamasama membuat proyek ini berhasil.

\section{Desember 2001}




\section{PRAKATA}

\section{Dr. Untung Iskandar}

Direktur Jenderal Bina Produksi Kehutanan

Departemen Kehutanan

Sebagaimana telah kita ketahui bersama bahwa hutan mempunyai nilai dan manfaat yang sangat penting bagi kehidupan manusia, baik manfaat ekologi, sosial, budaya maupun ekonomi. Bagi Indonesia, hutan juga merupakan modal pembangunan. Oleh karena itu, keberadaan hutan harus dipertahankan dan pemanfaat hasil hutannya harus diatur sedemikian rupa sehingga produktivitas hutan tersebut dapat terjaga dengan baik serta dampak negatif dari pemanfaatan hutan tersebut dapat ditekan serendah mungkin.

Peraturan-peraturan, pedoman-pedoman, petunjukpetunjuk teknis serta petunjuk pelaksanaan tentang pemanfaatan hutan telah banyak dikeluarkan oleh Departemen Kehutanan sebagai pegangan pelaksanaan pengelolaan hutan di Indonesia. Khusus mengenai kegiatan logging, Direktorat Jenderal Pengelolaan Hutan Produksi telah menerbitkan Surat Edaran No. 274/VI-PHA/2001 tanggal 23 Pebruari 2001 perihal Reduced Impact Logging (RIL). SuratEdaran ini pada dasarnya merupakan suatu pedoman teknis kepada unit-unit pengusahaan hutan alam yang akan melakukan kegiatan pembalakan hutan. Dengan terbitnya buku "PEDOMAN REDUCED IMPACT LOGGING INDONESIA' ini, maka telah bertambah lagi karya di bidang kehutanan di Indonesia. Buku Pedoman Reduced Impact Logging ini memiliki kekhasan tersendiri. 
Mengingat buku ini disusun berdasarkan hasil uji coba di lapangan dalam skala komersial, maka buku ini dapat dipakai sebagai pegangan di lapangan baik oleh perusahaan $\mathrm{HPH}$, para supervisor serta para operator di lapangan. Buku ini dapat juga dijadikan sebagai buku pegangan untuk pelatihanpelatihan tentang RIL baik yang dilakukan oleh pemerintah maupun oleh pihak lain. Format yang dipilih oleh para penulis buku ini merupakan format yang mudah dipahami oleh para praktisi serta mudah untuk dibawa ke lapangan.

Pada kesempatan ini, kami mengucapkan terima kasih kepada para penyusun buku ini, kepada ITTO yang telah memberikan dana untuk terlaksananya kegiatan penelitian Reduced Impact Logging (RIL) sebagai dasar munculnya penyusunan buku ini melalui ITTO Project PD 12/97 Rev. 1(F), kepada CIFOR dan Badan Litbang Kehutanan yang telah berhasil menyelesaikan implementasi project tersebut, kepada PT INHUTANI II yang telah bekerjasama dalam pelaksanaan penelitian RIL ini, serta kepada semua pihak yang telah membantu terwujudnya buku ini, baik secara langsung maupun tidak langsung.

Akhirnya, semoga buku "PEDOMAN REDUCED IMPACT LOGGING INDONESIA' ini dapat mencapai tujuan dan sasaran yang tepat, dan bermanfaat bagi keberhasilan pengelolaan hutan yang lestari, dapat segera disosialisasikan di lapangan sehingga para pengusaha kehutanan, para supervisor dan para operator terbantu dalam melaksanakan kegiatan logging dengan sistem TPTI yang benar. Diharapkan juga bahwa buku ini dapat dijadikan acuan untuk mengelola hutan di era desentralisasi, khususnya yang berkaitan dengan kegiatan pemanenan hutan.

Jakarta, Desember 2001 


\section{PRAKATA}

Ir. H. Arifin Trihastoyo, MM

Direktur Utama

PT. Inhutani II

Arti penting hutan bagi umat manusia sudah tidak terbantahkan, mengingat perannya selaku penyangga kehidupan yang dapat memberikan multi-manfaat, baik manfaat lingkungan, manfaat sosial dan manfaat ekonomi, yang harus dijaga kelestariannya.

Mencermati kejadian yang telah berlangsung sampai dengan saat ini, yaitu semakin parahnya kondisi hutan yang ada, khususnya hutan alam tropis, kiranya diperlukan adanya kesamaan pandang atas hutan itu sendiri. Rasanya akan lebih tepat apabila kita memandang hutan sebagai suatu proses produksi alam, yang akan mengolah bahan baku berupa air, mineral dan udara dengan menggunakan energi matahari untuk menghasilkan ketiga manfaat di atas secara lestari dan bukan sebagai komoditi dalam bentuk deposit seperti halnya barang tambang.

Berkenaan dengan diterbitkannya buku panduan tentang Reduced Impact Logging (RIL) atau Pembalakan Berdampak Rendah oleh CIFOR sebagai lembaga peneliti internasional yang merupakan hasil kerjasama dengan PT. Inhutani II sangat kami sambut baik, karena diharapkan akan sangat menunjang upaya untuk menjaga kelestarian dan meningkatkan kualitas proses produksi alam dalam 
bentuk hutan guna menghasilkan manfaat secara maksimal dan lestari, bagi kehidupan manusia.

Semoga kerjasama yang telah terjalin dapat terus berlangsung dan dapat secara maksimal memberikan sumbangan, baik bagi kemajuan ilmu kehutnan maupun dalam kegiatan pengelolaan hutan.

Jakarta, November 2001 


\section{PRAKATA}

Dari

Tim Penyusun

Buku Prinsip dan Praktik Pemanenan Hutan di Indonesia (2000) telah diterbitkan sebagai suatu dasar praktek pemanenan kayu di areal Hutan Produksi Tetap dan Hutan Produksi Terbatas di Indonesia. Buku tersebut berisi standar-standar mengenai APA yang harus dilakukan di dalam perencanaan dan pelaksanaan kegiatan pemanenan kayu di hutan alam dan MENGAPA kegiatan tertentu harus dilakukan. Buku Pedoman Reduced Impact Logging (RIL) Indonesia ini menjelaskan mekanisme BAGAIMANA standar-standar tersebut di atas dapat diterapkan di lapangan atau "bagaimana mengerjakan pekerjaan tersebut".

Penyaradan dengan traktor-terutama "crawler" dan "skidder"- adalah subsistem penyaradan yang paling umum $( \pm 90 \%)$ dipergunakan dalam sistem pemanenan kayu dengan sistem Tebang Pilih Tanam Indonesia (TPTI). Melihat kenyataan bahwa sistem-sistem pemanenan kayu yang lebih berwawasan lingkungan (seperti sistem kabel, helikopter maupun balon) masih kurang atau belum di kenal di Indonesia, dan karena biaya produksi kayu sistem-sistem tersebut, maka Pedoman RIL ini hanya berkonsentrasi pada pendekatan ground based RIL yang dapat diterapkan di hutan dataran rendah dan dataran tinggi (pegunungan) di Indonesia. 
Buku ini telah dipersiapkan sebagai Pedoman RIL dalam sistem TPTI di hutan alam tropika, berdasarkan buku Prinsip dan Praktik Pemanenan Hutan di Indonesia (2000), Buku Saku Reduced Impact Logging (Elias, 1999) dan buku Ground based Reduced-Impact Logging Guidelines for Lowland and Hill Dipterocarp Forest in Indonesia (Sist, Dykstra dan Fimbel, 1998). Input teknis lainnya diperoleh dari hasil penelitian Reduced Impact Logging yang dibiayai oleh International Tropical Timber Organization (ITTO) dalam proyek Forest Science and Sustainability: Bulungan Model Forest (PD 12/97 Rev. 1(F)); buku The Code of Practice for Forest Harvesting in Asia-Pacific (1999), industri Indonesia dan berdasarkan situasi dan kondisi aktual di hutan-hutan alam tropika Indonesia.

Kelompok target dari pedoman ini adalah supervisor produksi, perencana RIL, inspektor blok, perencana jaringan jalan, supervisor pembuatan jalan, mandor pembuatan jalan, operator mesin-mesin pembuatan dan pemeliharaan jalan, operator chainsaw, operator traktor dan helper. 


\section{ISI PEDOMAN RIL INDONESIA}

PRAKATA

iii

PENDAHULUAN

- PERENCANAAN PEMANENAN 5

- Sebelum Perencanaan Pemanenan 6

- Penataan Zona Areal Hutan 8

- Perencanaan Pemanenan 12

- OPERASI PEMANANEN 51

- Supervisi Operasi Pemanenan Kayu 52

- Operasi Penebangan 57

- Operasi Penyaradan dan Operasi di TPN 73

- PEMELIHARAAN, KESEHATAN KAMP DAN KESELAMATAN KERJA

- Pemeliharaan dan Servis 90

- Kesehatan Kamp 95

- Keselamatan Kerja 98

- KEGIATAN PASCA PEMANENAN KAYU 101

- Penutupan Jalan 102

- Penutupan Jalan Sarad 103

- Penutupan Penyeberangan Sementara 104

- Penutupan Tambang Batu (Quarry) 106

- Penutupan TPN 107

- Penutupan Kamp dan Bengkel 108

- Pemeliharaan Rutin 109

DAFTAR PUSTAKA 113

BAHAN BACAAN YANG DISARANKAN 114 


\section{PENDAHULUAN}

\section{Latar belakang pembuatan Pedoman RIL Indonesia}

Pengelolaan dan pemanenan hutan alam Indonesia diatur dalam sistem Tebang Pilih Tanam Indonesia (TPTI). Praktek Reduced Impact Logging (RIL) sebetulnya sudah direkomendasikan di dalam TPTI, namun jarang diterapkan di lapangan karena berbagai alasan, antara lain:

1. Kurangnya pengawasan terhadap praktek pemanenan kayu.

2. Kurangnya ketegasan dalam pelaksanaan RIL.

3. Kurangnya pemahaman keuntungan dari pelaksanaan RIL.

4. Kurangnya pemahaman terhadap tahapan yang diperlukan dalam pelaksanaan RIL dan kurangnya keahlian khusus.

Pada umumnya sudah diakui bahwa praktek pemanenan kayu yang berlangsung hingga saat ini perlu diperbaiki atau disempurnakan untuk memperoleh kondisi hutan yang lebih baik pada siklus tebang berikutnya. Sebagai anggota International Tropical Timber Organization (ITTO), pengakuan yang dikemukakan oleh rimbawan-rimbawan Indonesia ini ada kaitannya dengan ITTO's Year 2000 Objectives untuk mencapai pengelolaan hutan lestari.

Kemajuan dalam pengelolaan hutan lestari akan dipromosikan dengan penerapan teknik RIL, yaitu suatu tehnik yang bertujuan mengurangi kerusakan pada tanah dan tegakan tinggal serta dampaknya terhadap kehidupan satwa liar. 


\section{Apa itu RIL?}

RIL adalah suatu pendekatan sistematis dalam perencanaan, pelaksanaan, pemantauan dan evaluasi terhadap pemanenan kayu.

RIL merupakan penyempurnaan praktek pembuatan jalan, penebangan dan penyaradan yang saat ini sudah ada.

RIL memerlukan wawasan kedepan dan keterampilan yang baik dari para operatornya serta adanya kebijakan/ policy tentang lingkungan yang mendukungnya.

\section{Mengapa dengan RIL?}

Para manajer hutan makin dituntut untuk meningkatkan kualitas kegiatan pengelolaannya dan melaksanakan pengelolaan hutan dengan standar yang lebih baik. Salah satu cara melakukan hal tersebut adalah dengan penerapan teknik RIL. 


\section{Ada banyak alasan mengapa dengan RIL?}
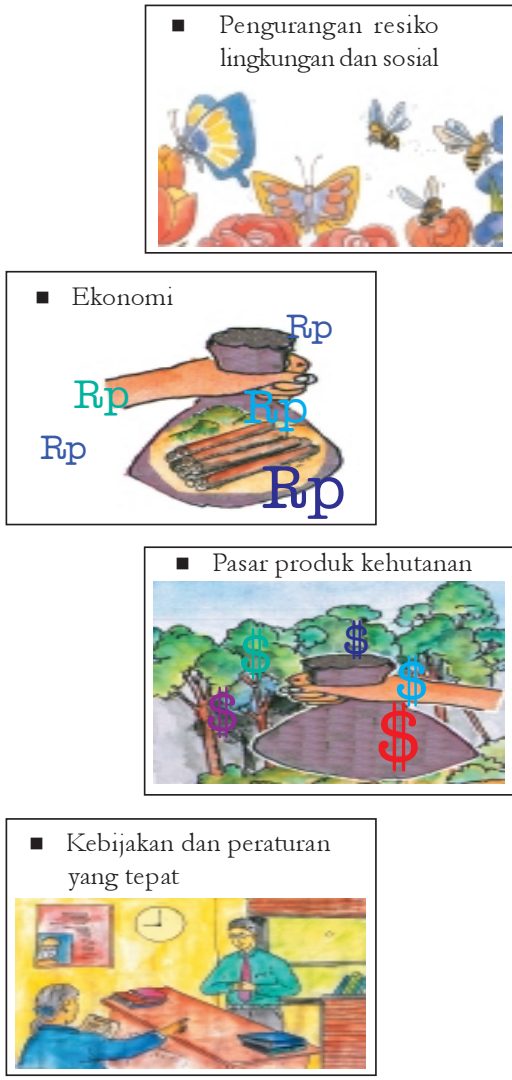


\section{IMPLEMENTASI RIL DALAM TPTI}

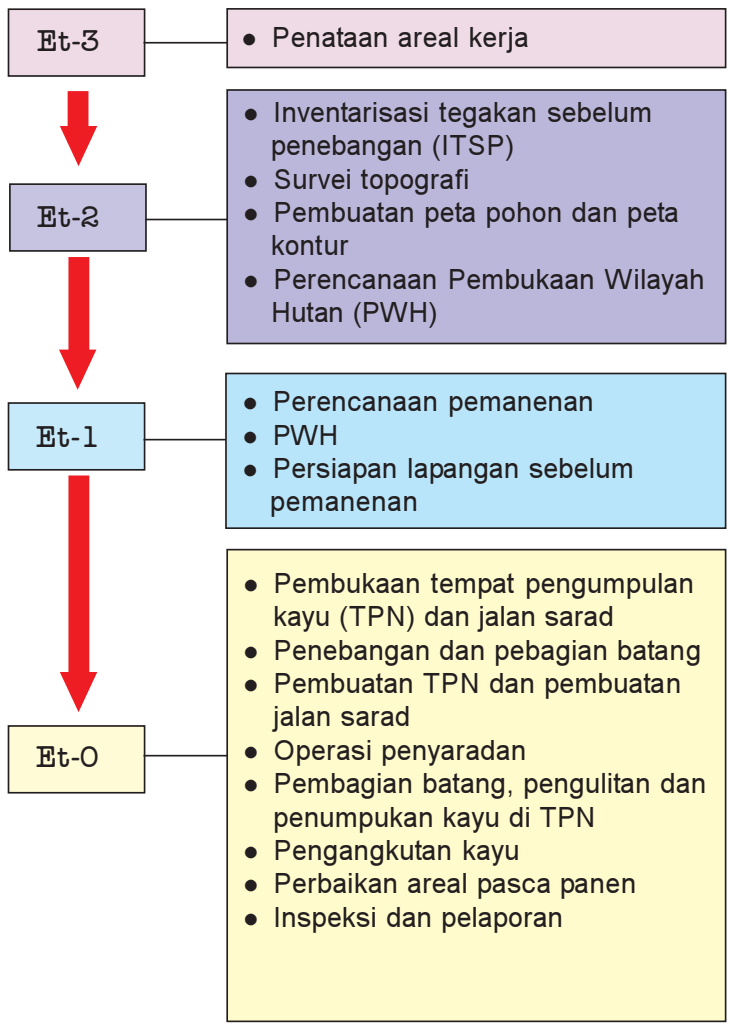

Et-0 = tahun waktu pemanenan; $(-)=$ tahun sebelum pemanenan 


\section{PERENCANAAN PEMANENAN}

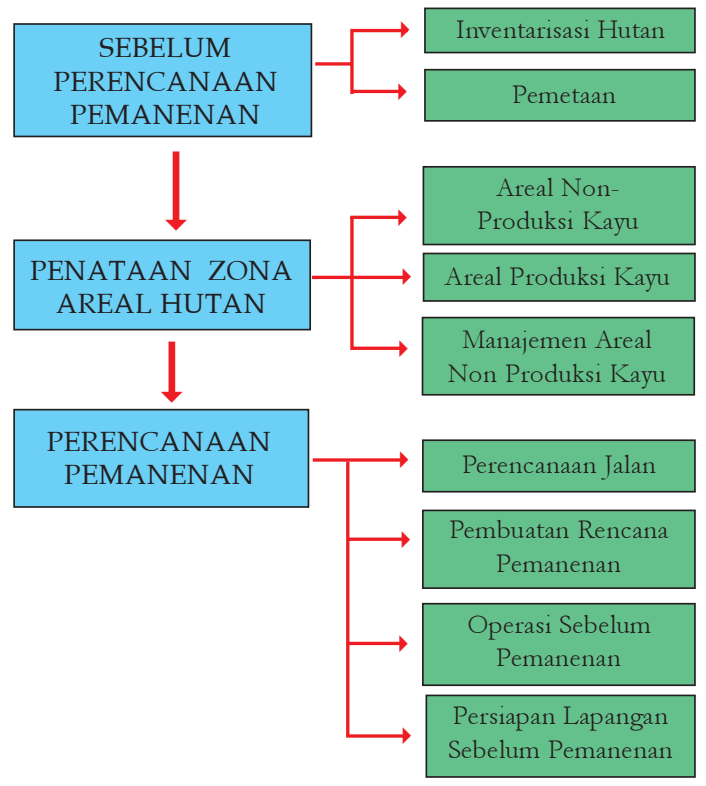




\section{SEBELUM PERENCANAAN PEMANENAN}

\section{Iventarisasi Hutan}

Tahapan pertama adalah melaksanakan inventarisasi hutan yang diikuti oleh kegiatan pemetaan topografi dan lokasi pohon.

Manual berikut ini menyajikan informasi secara rinci bagaimana mengerjakan hal tersebut :

- Pedoman dan Petunjuk Teknis Tebang Pilih Tanam Indonesia (TPTI) pada Hutan Alam Daratan (Departemen Kehutanan RI, 1993)

- Petunjuk Dasar dalam Timber Cruising dan Survei Topografi (Ruslim, 1998)

- Prosedur Survei Topografi Hutan (TFF\&APHI, 2001)

\section{Persiapan Pemetaan}

Pemetaan kontur dan lokasi pohon skala 1:2.000 - 1:5.000 dengan interval garis kontur 5-10 m dapat dihasilkan secara manual atau dengan menggunakan suatu program komputer, misalnya :

- FIEPLP (Forest Inventory and Product Linking Programme) dari TROPENBOS Foundation Project

- GENESIS dan GENAMAP Programme dari SFMPGTZ Project

- ROADENG Software

- SIPTOP (Sistem Informasi Pohon dan Topografi) dari PT. INHUTANI I 
Contoh tally sheet dan data yang dikumpulkan dalam survei dan inventarisasi hutan dan topografi.

Tally sheet inventarisasi hutan

\begin{tabular}{|c|c|c|c|c|c|c|c|c|}
\hline $\begin{array}{c}\text { No. } \\
\text { Pohon }\end{array}$ & $\begin{array}{c}\text { Kode } \\
\text { Jenis }\end{array}$ & $\begin{array}{c}\text { Diam. } \\
(\mathrm{cm})\end{array}$ & $\begin{array}{c}\text { Tinggi } \\
(\mathrm{m})\end{array}$ & Kode & $\begin{array}{c}\text { Vol } \\
\left(\mathrm{m}^{3}\right)\end{array}$ & $\mathrm{X}$ & $\mathrm{Y}$ & $\begin{array}{l}\text { Kete- } \\
\text { rangan }\end{array}$ \\
\hline & & & & & & & & \\
\hline 5 & $\mathrm{MD}$ & 40 & 18 & 4 & & & & \\
\hline 4 & $\mathrm{MD}$ & 55 & 16 & 1 & & & & \\
\hline 3 & $\mathrm{NYR}$ & 37 & 16 & 4 & & & & \\
\hline 2 & MD & 25 & 12 & 4 & & & & \\
\hline 001 & MM & 80 & 22 & 1 & & & & \\
\hline
\end{tabular}

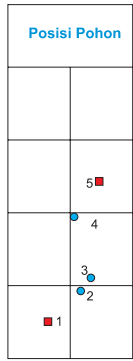

Tally sheet survei topografi

\begin{tabular}{|c|c|c|c|c|c|l|}
\hline Stasion & $\begin{array}{c}\text { Azimuth } \\
\left({ }^{\circ}\right)\end{array}$ & $\begin{array}{c}\text { Jarak } \\
\text { Datar }(\mathrm{m})\end{array}$ & $\begin{array}{c}\text { Kemi- } \\
\text { ringan } \\
(\%)\end{array}$ & $\begin{array}{c}\text { Beda } \\
\text { Tinggi } \\
(\mathrm{m})\end{array}$ & $\begin{array}{c}\text { Ketinggian } \\
\text { Tempat dpl } \\
(\mathrm{m})\end{array}$ & $\begin{array}{l}\text { Koreksi } \\
\text { Ketinggian } \\
\text { Tempat }\end{array}$ \\
\hline 3 & & & & & & \\
\hline & 360 & 20.4 & +19 & & & \\
\hline 2 & & & & & & \\
\hline 1 & 360 & 20.4 & +19 & & & \\
\hline 0 & 360 & 10.1 & +14 & & & \\
\hline
\end{tabular}

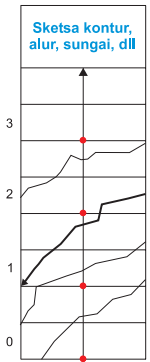




\section{PENATAAN ZONA AREAL HUTAN}

\section{Areal Non Produksi Kayu}

- Identifikasi areal non-produksi kayu merupakan hal yang penting dalam menentukan dan menetapkan areal produktif

- Zona areal produksi kayu = luas total areal hutan unit manajemen - luas areal non produksi kayu

- Zona areal produksi kayu menjadi dasar luas areal dalam penentuan jatah tebangan tahunan (AAC)

- Zona-zona yang dikeluarkan dari areal produksi kayu antara lain :

* Zona perlindungan dan konservasi

* Zona hutan masyarakat dan masyarakat lokal

* Zona konservasi keanekaragaman hayati

* Zona konservasi satwa liar

* Zona penelitian ilmiah

* Zona penyangga, antara lain :

- Kawasan cagar budaya

- Areal penyangga tepi pantai, goba, danau dan mata air

- Areal rawan longsor

- Areal penyangga kanan-kiri sungai 


\section{Areal Produksi Kayu}

\section{- Contoh peta penataan zona areal hutan}

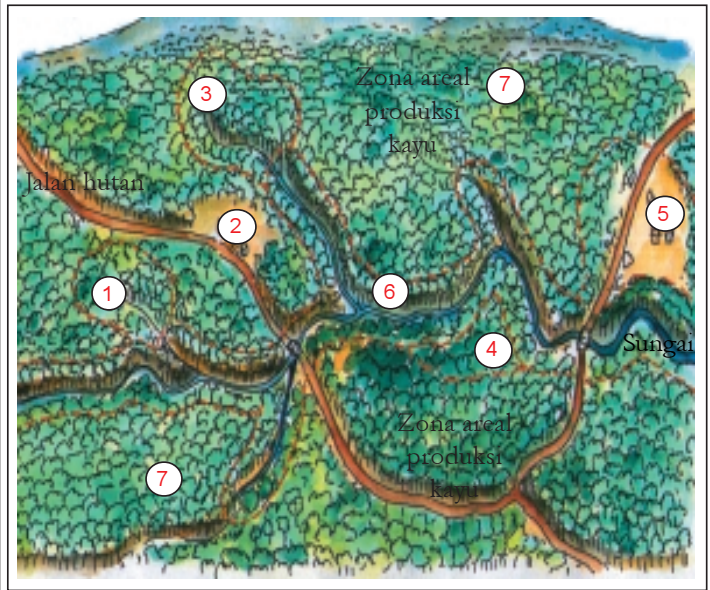

Keterangan

1. Zona konservasi keanekaragaman hayati

2, 5. Zona desa yang dikelilingi hutan masyarakat

3. Zona hutan untuk penelitian ilmiah

4. Zona konservasi satwa liar

6. Zona konservasi daerah aliran sungi

7. Zona areal produksi kayu 


\section{- Areal penyangga}

\begin{tabular}{|l|l|}
\hline & \multicolumn{1}{|c|}{ Lebar Minimum Zona Penyangga } \\
\hline Kawasan cagar budaya & $30 \mathrm{~m}$ \\
\hline $\begin{array}{l}\text { Danau } \\
\text { Goba } \\
\text { Pantai } \\
\text { Mata air }\end{array}$ & $\begin{array}{l}\text { Jika lereng }<17 \%=50 \mathrm{~m} \\
\text { Jika lereng }>17 \%=100 \mathrm{~m}\end{array}$ \\
\hline Sungai & $\begin{array}{l}\text { Sungai kelas } 1=30 \mathrm{~m} \text { di setiap sisi } \\
\text { Sungai kelas 2 }=20 \mathrm{~m} \text { di setiap sisi } \\
\text { Sungai kelas } 3=10 \mathrm{~m} \text { di setiap sisi }\end{array}$ \\
\hline Aliran air & $\begin{array}{l}\text { Daerah aliran sungai 2 ha, tidak boleh } \\
\text { menebang pohon yang berada dalam jarak } 5 \mathrm{~m} \\
\text { dari setiap sisinya }\end{array}$ \\
\hline
\end{tabular}

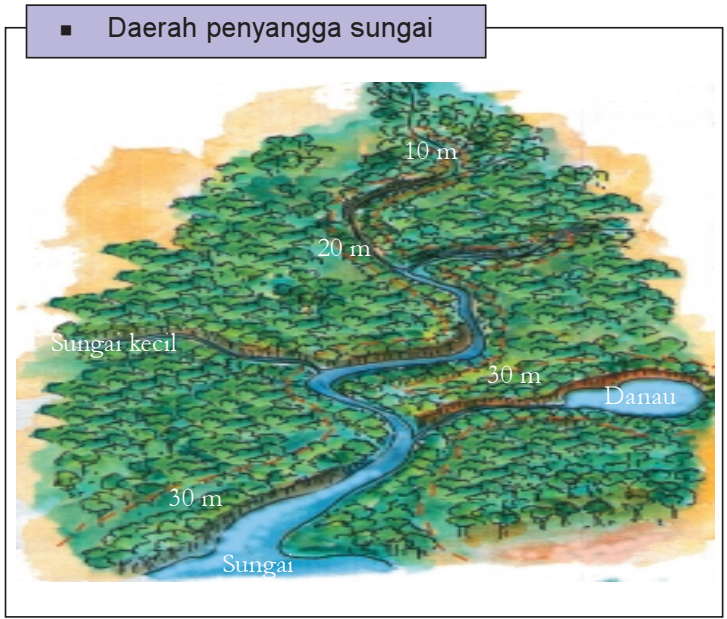




\section{Manajemen Areal Non Produksi Kayu}

Areal non-produksi kayu dikelola sebagai berikut :

- Tidak boleh ada penebangan di kawasan tersebut atau di zona penyangga

- Mesin-mesin tidak boleh masuk ke kawasan tersebut, terkecuali pada sungai yang diijinkan untuk diseberangi

- Tidak boleh ada pekerjaan tanah atau tumpahan pekerjaan tanah jatuh ke dalam kawasan tersebut atau zona penyangganya

- Tidak boleh membuang serpihan penebangan (cabang-cabang dan rating-ranting) ke dalam kawasan tersebut atau di zona penyangganya

- Bila memungkinkan, pohon-pohon harus ditebang menjauhi zona penyangga dan sungai

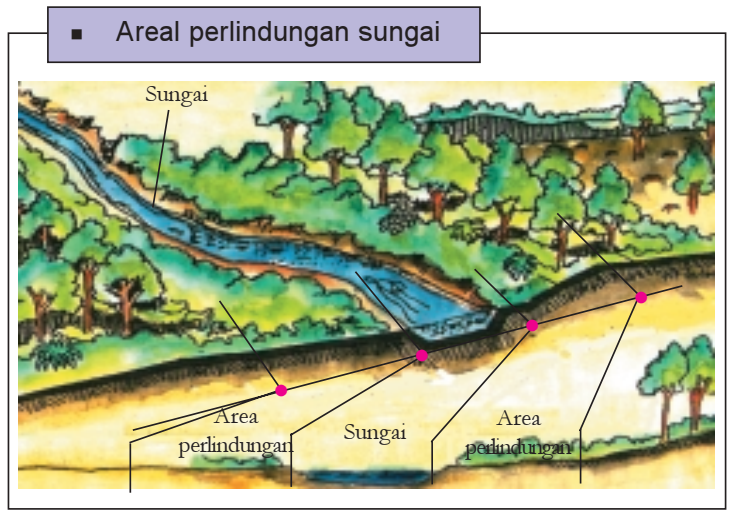




\section{PERENCANAAN PEMANENAN}

\section{Perencanaan Jalan}
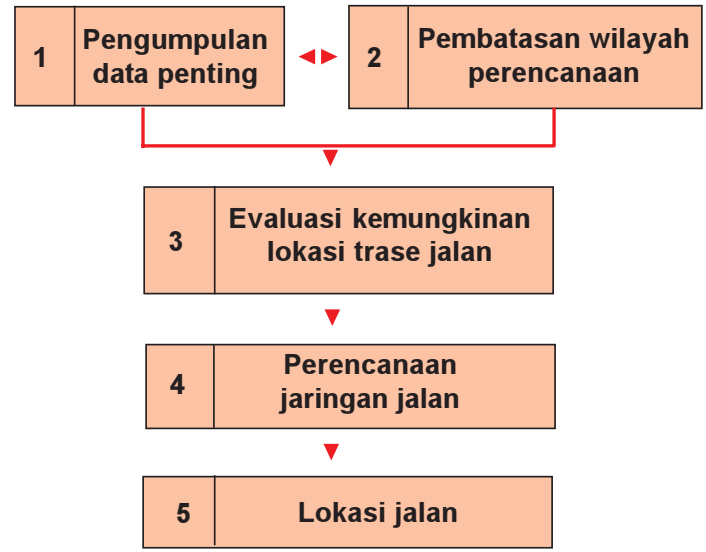

Buku-buku berikut ini menjelaskan secara rinci bagaimana mengerjakan perencanaan jalan :

- A Manual for the Planning, Design and Construction of Forest Roads in Step Terrain (FAO, undated)

- Pembukaan Wilayah Hutan (Elias, 1997) 


\section{- Pengumpulan data penting}

Data penting yang perlu di kumpulkan terdiri dari :

- Potret udara

- Peta Topografi, skala 1:5.000 sampai 1:25.000

- Peta Keadaan Hutan, skala 1:25.000 atau 1:50.000

- Peta Tanah

- Peta Geologi

- Pedoman dan Peraturan Pembukaan Wilayah Hutan

- Biaya pembuatan jalan

- Biaya pemanenan kayu dan harga kayu

- Rencana Manajemen Hutan, dll.

- Pembatasan wilayah perencanaan

\section{Contoh pembatasan wilayah perencanaan}




\section{- Evaluasi kemungkinan lokasi trase jalan}

- Perlu diidentifikasi :

- Tempat-tempat akses ke jalan umum dan jalan hutan yang sudah ada

- Tempat-tempat menguntungkan untuk konstruksi jalan dan pemanenan kayu

- Bagian-bagian yang datar yang cocok untuk belokan, trase jalan yang lebih baik dan tempat landing

- Deposit batuan (quarry)

- Tempat yang baik untuk jembatan

- Tempat-tempat yang curam

- Rawa-rawa

- Tempat-tempat rawan longsor

- Lembah-lembah yang dalam

- Hutan lindung

Contoh titik-titik (zona) kardinal positif dan negatif

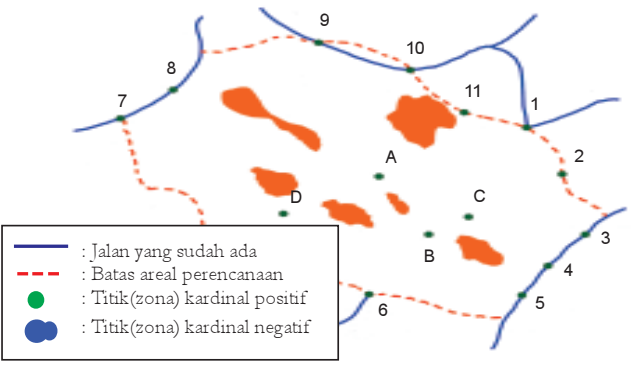




\section{- Perencanaan jaringan jalan}

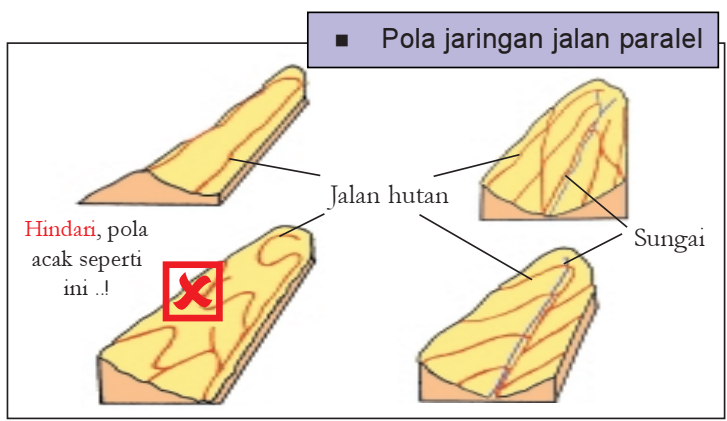

\section{- Pola jaringan jalan mengelilingi}

a.

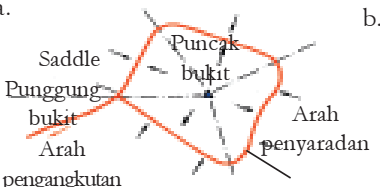

pengangkutan

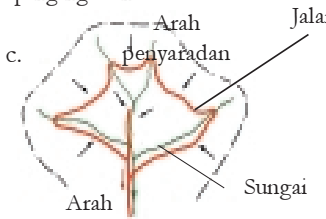

pengangkutan b.

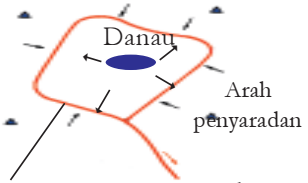

Arah pengangkutan

d.

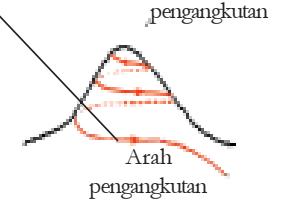


- Perencanaan jaringan jalan di atas peta kontur (skala 1:5.000 sd. 1:25.000)

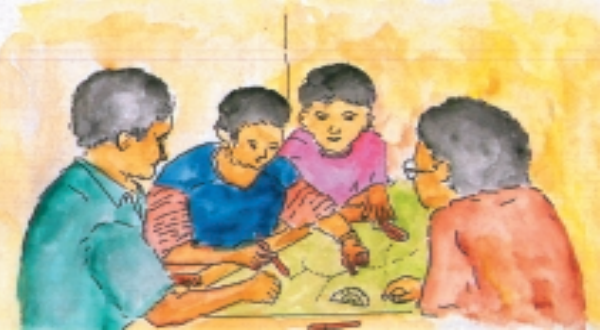

Kriteria perencanaan jalan: Maksimum kemiringan memanjang jalan adalah jalan utama $=10 \%$; jalan cabang $=15 \%$; jalan ranting $=18 \%$

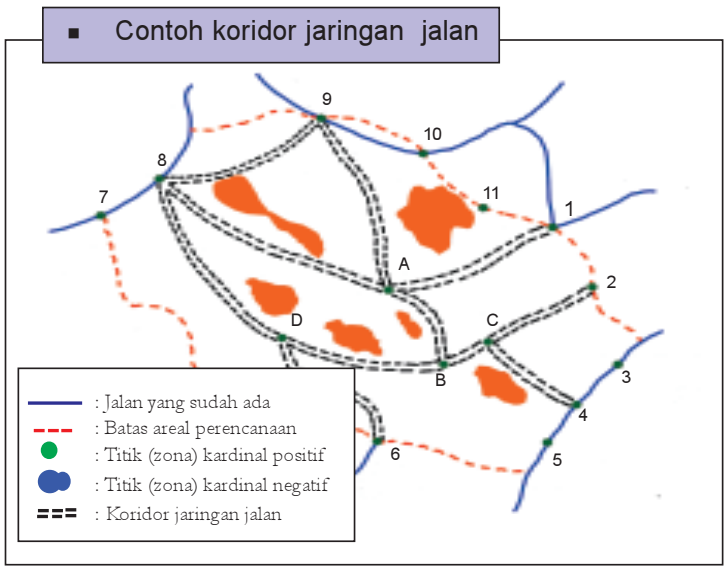


- Pilihlah!

Lokasi trase jalan di tempat yang stabil
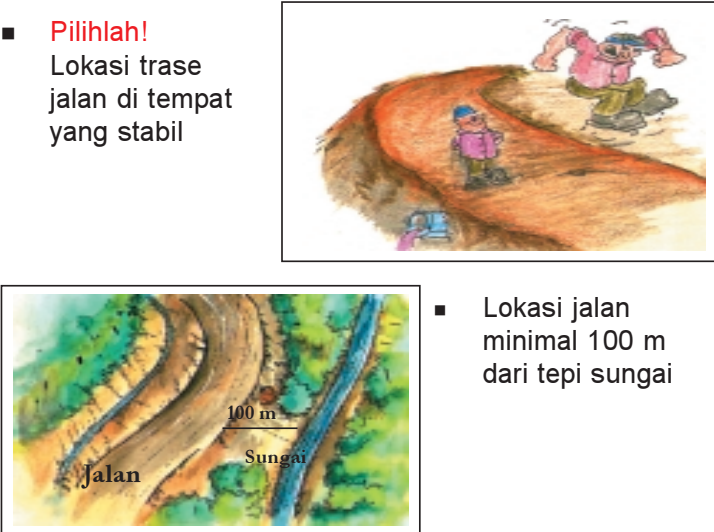

Lokasi jalan minimal $100 \mathrm{~m}$ dari tepi sungai

- Hindari!

Tempat-tempat (zona-zona) kardinal negatif, contoh: tempat keramat

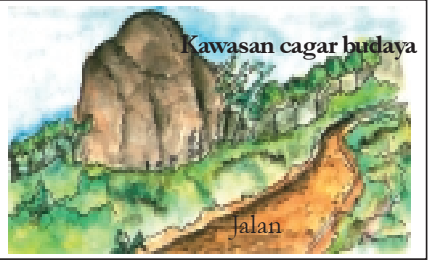

- Hindari!

Tempat-tempat rawan longsor

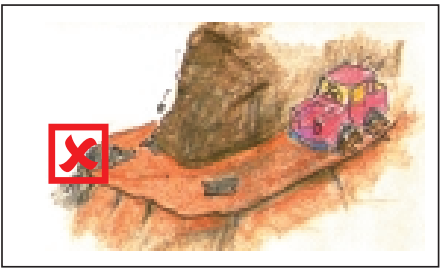




\section{- Lokasi jalan}

\section{- Jalan kontur/lereng}
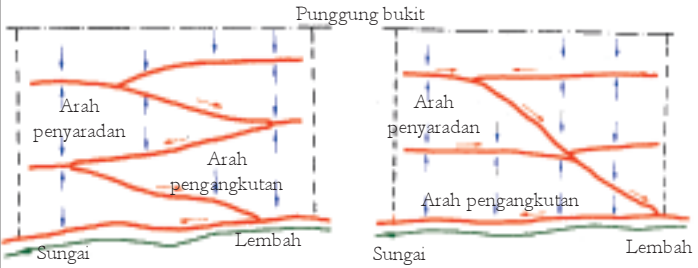

\section{- Jalan punggung}

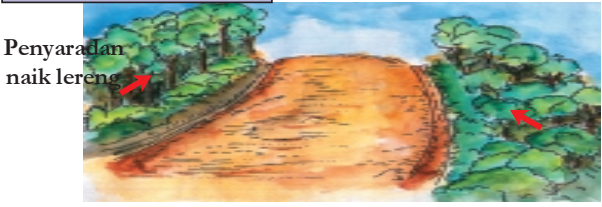

\section{- Jalan lembah}

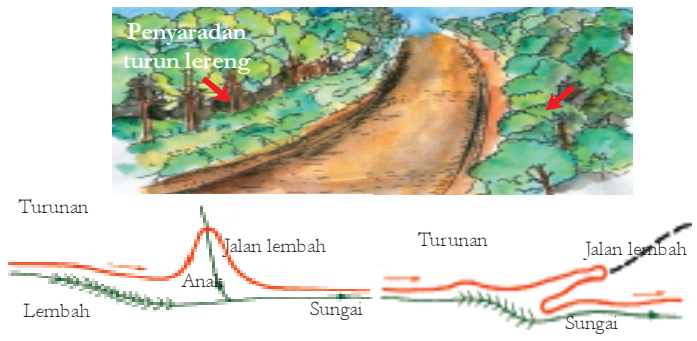


Tabel konversi untuk pengukuran kemiringan lapangan

\begin{tabular}{|c|c|c|c|c|c|c|c|c|c|c|c|c|c|}
\hline \multirow{2}{*}{$\begin{array}{l}\text { Dera- } \\
\text { jat } \\
(9)\end{array}$} & \multirow{2}{*}{$\begin{array}{l}\text { Per } \\
\text { sen } \\
(\%)\end{array}$} & \multicolumn{12}{|c|}{$\mathrm{Jarak}(\mathrm{m})$} \\
\hline & & 4 & 5 & 6 & 7 & 8 & 9 & 10 & 20 & 30 & 40 & 50 & 100 \\
\hline 1 & 1,7 & 0,00 & 0,00 & 0,00 & 0,00 & 0,00 & 0,00 & 0,00 & 0,00 & 0,00 & 0,01 & 0,01 & 0,02 \\
\hline 2 & 3,5 & 0,00 & 0,00 & 0,00 & 0,00 & 0,00 & 0,01 & 0,01 & 0,01 & 0,02 & 0,02 & 0,03 & 0,06 \\
\hline 3 & 5,2 & 0,01 & 0,01 & 0,01 & 0,01 & 0,01 & 0,01 & 0,01 & 0,03 & 0,04 & 0,05 & 0,07 & 0,14 \\
\hline 4 & 7,0 & 0,01 & 0,01 & 0,01 & 0,02 & 0,02 & 0,02 & 0,02 & 0,05 & 0,07 & 0,10 & 0,12 & 0,24 \\
\hline 5 & 8,7 & 0,02 & 0,02 & 0,02 & 0,03 & 0,03 & 0,03 & 0,04 & 0,08 & 0,11 & 0,15 & 0,19 & 0,38 \\
\hline 6 & 10,5 & 0,02 & 0,03 & 0,03 & 0,04 & 0,04 & 0,05 & 0,05 & 0,11 & 0,16 & 0,22 & 0,27 & 0,55 \\
\hline 7 & 12,3 & 0,03 & 0,04 & 0,04 & 0,05 & 0,06 & 0,07 & 0,07 & 0,15 & 0,22 & 0,30 & 0,37 & 0,75 \\
\hline 8 & 14,1 & 0,04 & 0,05 & 0,06 & 0,07 & 0,08 & 0,09 & 0,10 & 0,19 & 0,29 & 0,39 & 0,49 & 0,97 \\
\hline 9 & 15,8 & 0,05 & 0,06 & 0,07 & 0,09 & 0,10 & 0,11 & 0,12 & 0,25 & 0,37 & 0,49 & 0,62 & 1,23 \\
\hline 10 & 17,6 & 0,06 & 0,08 & 0,09 & 0,11 & 0,12 & 0,14 & 0,15 & 0,30 & 0,46 & 0,61 & 0,76 & 1,52 \\
\hline 11 & 19,4 & 0,07 & 0,09 & 0,11 & 0,13 & 0,15 & 0,17 & 0,18 & 0,37 & 0,55 & 0,73 & 0,92 & 1,84 \\
\hline 12 & 21,3 & 0,09 & 0,11 & 0,13 & 0,15 & 0,17 & 0,20 & 0,22 & 0,44 & 0,66 & 0,87 & 1,09 & 2,19 \\
\hline 13 & 23,1 & 0,10 & 0,13 & 0,15 & 0,18 & 0,21 & 0,23 & 0,26 & 0,51 & 0,77 & 1,03 & 1,28 & 2,56 \\
\hline 14 & 24,9 & 0,12 & 0,15 & 0,18 & 0,21 & 0,24 & 0,27 & 0,30 & 0,59 & 0,89 & 1,19 & 1,49 & 2,97 \\
\hline 15 & 26,8 & 0,14 & 0,17 & 0,20 & 0,24 & 0,27 & 0,31 & 0,34 & 0,68 & 1,02 & 1,36 & 1,70 & 3,41 \\
\hline 16 & 28,7 & 0,15 & 0,19 & 0,23 & 0,27 & 0,31 & 0,35 & 0,39 & 0,77 & 1,16 & 1,55 & 1,94 & 3,87 \\
\hline 17 & 30,6 & 0,17 & 0,22 & 0,26 & 0,31 & 0,35 & 0,39 & 0,44 & 0,87 & 1,31 & 1,75 & 2,18 & 4,37 \\
\hline 18 & 32,5 & 0,20 & 0,24 & 0,29 & 0,34 & 0,39 & 0,44 & 0,49 & 0,98 & 1,47 & 1,96 & 2,45 & 4,89 \\
\hline 19 & 34,4 & 0,22 & 0,27 & 0,33 & 0,38 & 0,44 & 0,49 & 0,54 & 1,09 & 1,63 & 2,18 & 2,72 & 5,45 \\
\hline 20 & 36,4 & 0,24 & 0,30 & 0,36 & 0,42 & 0,48 & 0,54 & 0,60 & 1,21 & 1,81 & 2,41 & 3,02 & 6,03 \\
\hline 21 & 38,4 & 0,27 & 0,33 & 0,40 & 0,46 & 0,53 & 0,60 & 0,66 & 1,33 & 1,99 & 2,66 & 3,32 & 6,64 \\
\hline 22 & 40,4 & 0,29 & 0,36 & 0,44 & 0,51 & 0,58 & 0,66 & 0,73 & 1,46 & 2,18 & 2,91 & 3,64 & 7,28 \\
\hline 23 & 42,4 & 0,32 & 0,40 & 0,48 & 0,56 & 0,64 & 0,72 & 0,79 & 1,59 & 2,38 & 3,18 & 3,97 & 7,95 \\
\hline 24 & 44,5 & 0,35 & 0,43 & 0,52 & 0,61 & 0,69 & 0,78 & 0,86 & 1,73 & 2,59 & 3,46 & 4,32 & 8,65 \\
\hline 25 & 46,6 & 0,37 & 0,47 & 0,56 & 0,66 & 0,75 & 0,84 & 0,94 & 1,87 & 2,81 & 3,75 & 4,68 & 9,37 \\
\hline 26 & 48,8 & 0,40 & 0,51 & 0,61 & 0,71 & 0,81 & 0,91 & 1,01 & 2,02 & 3,04 & 4,05 & 5,06 & 10,12 \\
\hline 27 & 51,0 & 0,44 & 0,54 & 0,65 & 0,76 & 0,87 & 0,98 & 1,09 & 2,18 & 3,27 & 4,36 & 5,45 & 10,90 \\
\hline 28 & 53,2 & 0,47 & 0,59 & 0,70 & 0,82 & 0,94 & 1,05 & 1,17 & 2,34 & 3,51 & 4,68 & 5,85 & 11,71 \\
\hline 29 & 55,4 & 0,50 & 0,63 & 0,75 & 0,88 & 1,00 & 1,13 & 1,25 & 2,51 & 3,76 & 5,02 & 6,27 & 12,54 \\
\hline 30 & 57,7 & 0,54 & 0,67 & 0,80 & 0,94 & 1,07 & 1,21 & 1,34 & 2,68 & 4,02 & 5,36 & 6,70 & 13,40 \\
\hline 31 & 60,1 & 0,57 & 0,71 & 0,86 & 1,00 & 1,14 & 1,29 & 1,43 & 2,86 & 4,28 & 5,71 & 7,14 & 14,28 \\
\hline 32 & 62,5 & 0,61 & 0,76 & 0,91 & 1,06 & 1,22 & 1,37 & 1,52 & 3,04 & 4,56 & 6,08 & 7,60 & 15,20 \\
\hline 33 & 64,9 & 0,65 & 0,81 & 0,97 & 1,13 & 1,29 & 1,45 & 1,61 & 3,23 & 4,84 & 6,45 & 8,07 & 16,13 \\
\hline 34 & 67,5 & 0,68 & 0,85 & 1,03 & 1,20 & 1,37 & 1,54 & 1,71 & 3,42 & 5,13 & 6,84 & 8,55 & 17,10 \\
\hline 35 & 70,0 & 0,72 & 0,90 & 1,09 & 1,27 & 1,45 & 1,63 & 1,81 & 3,62 & 5,43 & 7,23 & 9,04 & 18,08 \\
\hline 36 & 72,7 & 0,76 & 0,95 & 1,15 & 1,34 & 1,53 & 1,72 & 1,91 & 3,82 & 5,73 & 7,64 & 9,55 & 19,10 \\
\hline 37 & 75,4 & 0,81 & 1,01 & 1,21 & 1,41 & 1,61 & 1,81 & 2,01 & 4,03 & 6,04 & 8,05 & 10,07 & 20,14 \\
\hline 38 & 78,1 & 0,85 & 1,06 & 1,27 & 1,48 & 1,70 & 1,91 & 2,12 & 4,24 & 6,36 & 8,48 & 10,60 & 21,20 \\
\hline 39 & 81,0 & 0,89 & 1,11 & 1,34 & 1,56 & 1,78 & 2,01 & 2,23 & 4,46 & 6,69 & 8,91 & 11,14 & 22,29 \\
\hline 40 & 83,9 & 0,94 & 1,17 & 1,40 & 1,64 & 1,87 & 2,11 & 2,34 & 4,68 & 7,02 & 9,36 & 11,70 & 23,40 \\
\hline 41 & 86,9 & 0,98 & 1,23 & 1,47 & 1,72 & 1,96 & 2,21 & 2,45 & 4,91 & 7,36 & 9.81 & 12,26 & 24,53 \\
\hline 42 & 90,0 & 1,03 & 1,28 & 0,54 & 1,80 & 2,05 & 2,31 & 2,57 & 5,14 & 7,71 & 10,27 & 12.84 & 25,69 \\
\hline 43 & 93,3 & 1,07 & 1,34 & 1,61 & 1,88 & 2,15 & 2,42 & 2,69 & 5,37 & 8,06 & 10,75 & 13,43 & 26,86 \\
\hline 44 & 96,6 & 1,12 & 1,40 & 1,68 & 1,96 & 2,25 & 2,53 & 2,81 & 5,61 & 8,42 & 11,23 & 14,03 & 28,07 \\
\hline 45 & 100,0 & 1,17 & 1,46 & 1,76 & 2,05 & 2,34 & 2,64 & 2,93 & 5,86 & 8,79 & 11,72 & 14,64 & 29,29 \\
\hline
\end{tabular}


- Penandaan jalan

\begin{tabular}{|l|l|}
\hline Kategori & Penandaan di Lapangan \\
\hline Jalan utama & $\begin{array}{l}\text { Trase jalan ditandai cat merah 1 strip vertikal } \\
\text { setinggi mungkin pada kedua belah arah trase jalan }\end{array}$ \\
\hline $\begin{array}{l}\text { Jalan cabang dan } \\
\text { jalan ranting }\end{array}$ & $\begin{array}{l}\text { Trase jalan ditandai cat merah 1 strip vertikal } \\
\text { setinggi mungkin pada kedua belah arah trase jalan }\end{array}$ \\
\hline TPN & $\begin{array}{l}\text { Ditandai dengan huruf L dan nomor TPN sesuai } \\
\text { rencana pemanenan, pada pohon di lokasi TPN } \\
\text { (warna merah) }\end{array}$ \\
\hline Jembatan & Ditandai dengan huruf B (warna merah) \\
\hline Gorong-gorong & Ditandai dengan huruf C (warna merah) \\
\hline
\end{tabular}

- Penandaan trase jalan di lapangan

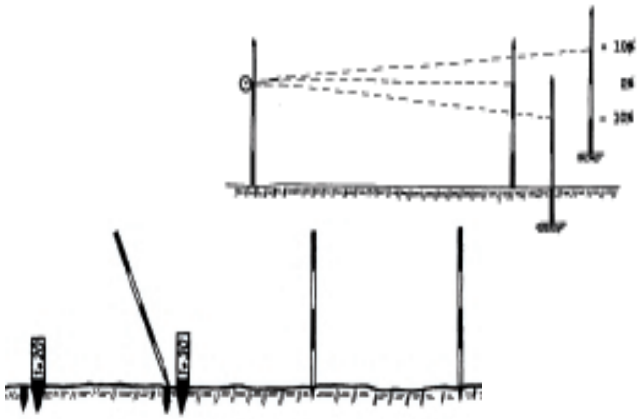

Trase jalan ditentukan dengan clinometer dan ditandai dengan pancang di lapangan 
- Garis perataan jalan dan gali-timbun
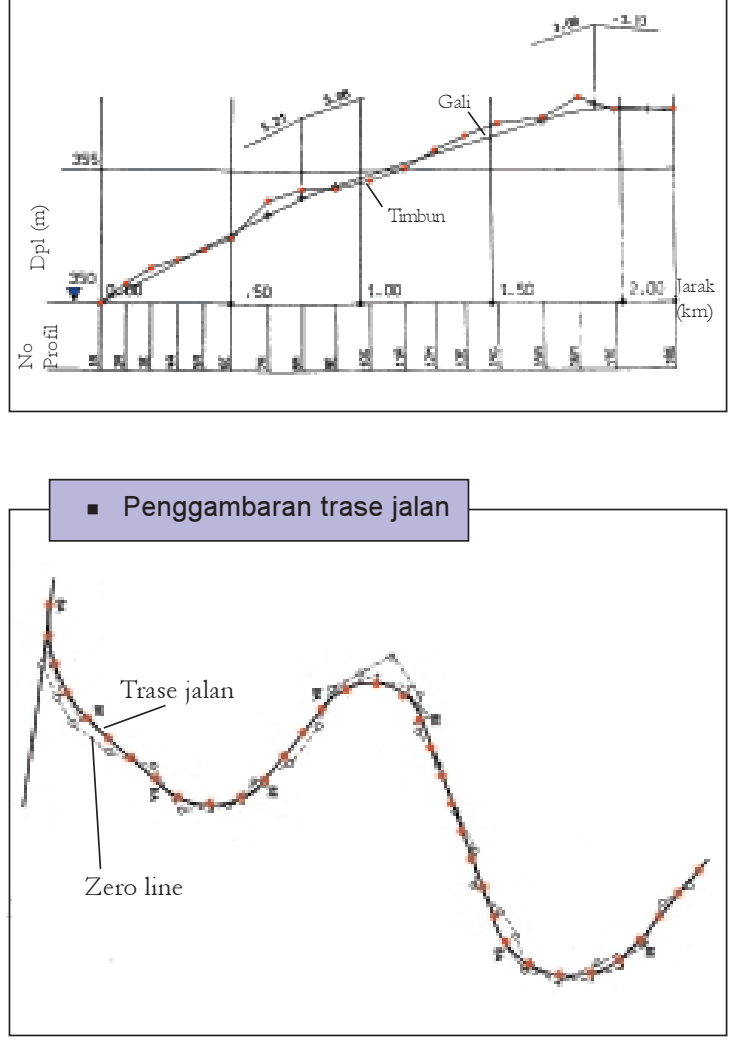


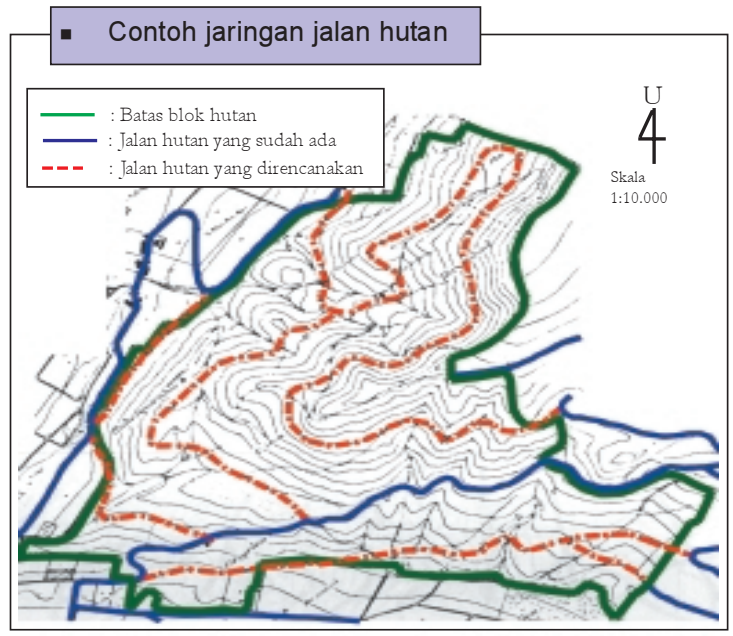


Pembuatan Rencana Pemanenan

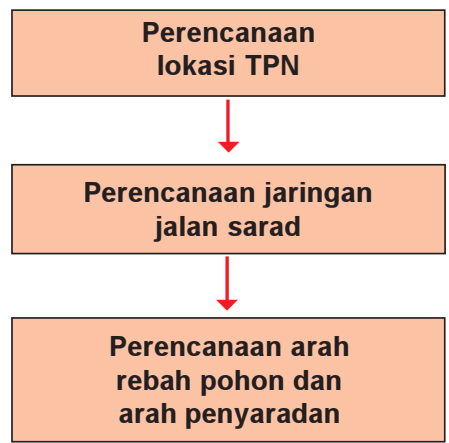




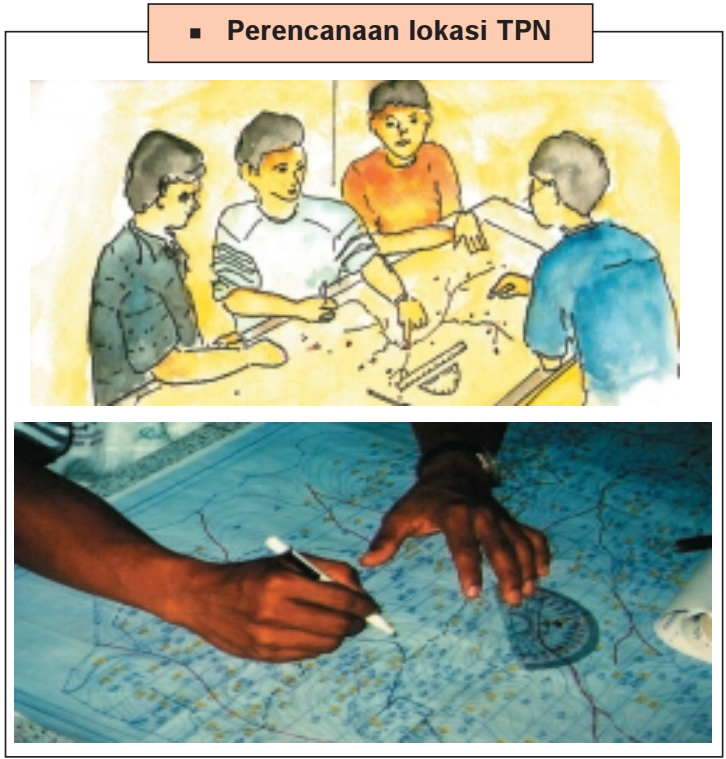

1. Pilih di lokasi yang luas dan cukup datar dengan kemiringan maksimum $6^{\circ}$

2. Usahakan di atas punggung bukit/pematang

3. Lokasi TPN tidak boleh terletak di dalam areal kawasan lindung dan zona penyangga

4. Lokasi TPN tidak berdekatan dengan sungai 


\section{- Perencanaan jaringan jalan sarad}

1. Jalan sarad didesain selurus mungkin mengikuti kontur

2. Jalan sarad harus menghindari daerah curam, jurang, daerah lembab/paya dan tanah yang labil

3. Jalan sarad harus menghindari sungai/kali/alur. Jika terpaksa harus dibuatkan jembatan penyeberangan sementara

4. Jalan sarad didesain untuk dipergunakan seintensif mungkin

5. Kemiringan jalan sarad maksimum $45 \%$

6. Jalan sarad tidak boleh masuk areal kawasan lindung dan daerah penyangganya

7. Jarak sarad diminimalkan

8. Lebar jalan sarad maksimum 4 meter 

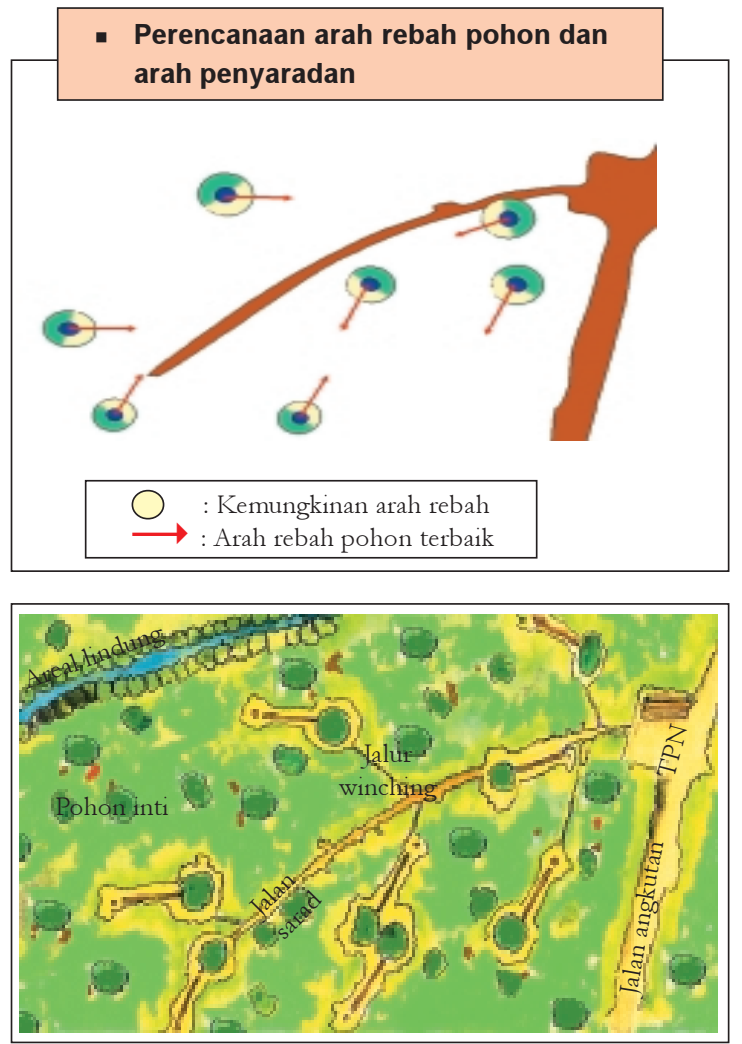


\section{Contoh Peta Rencana Pemanenan}

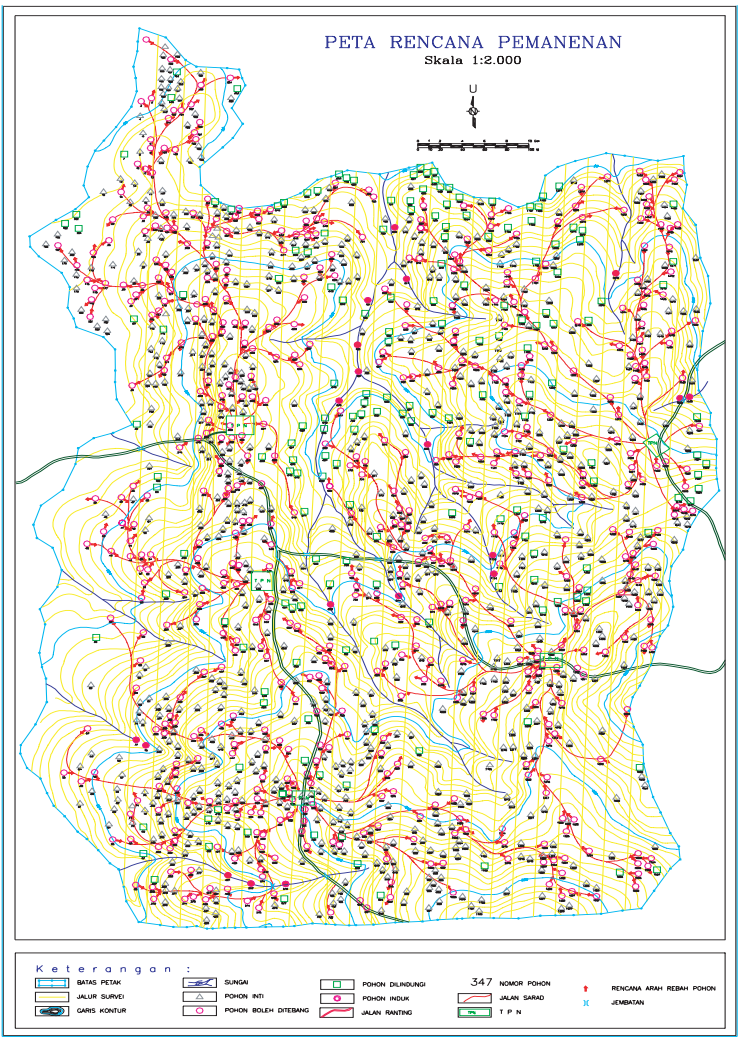


Operasi Sebelum Pemanenan

Specifikasi jalan

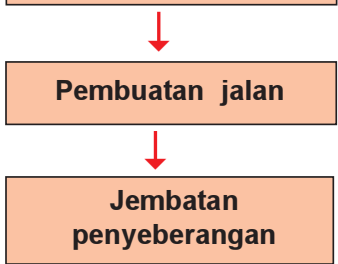




\section{Spesifikasi jalan}

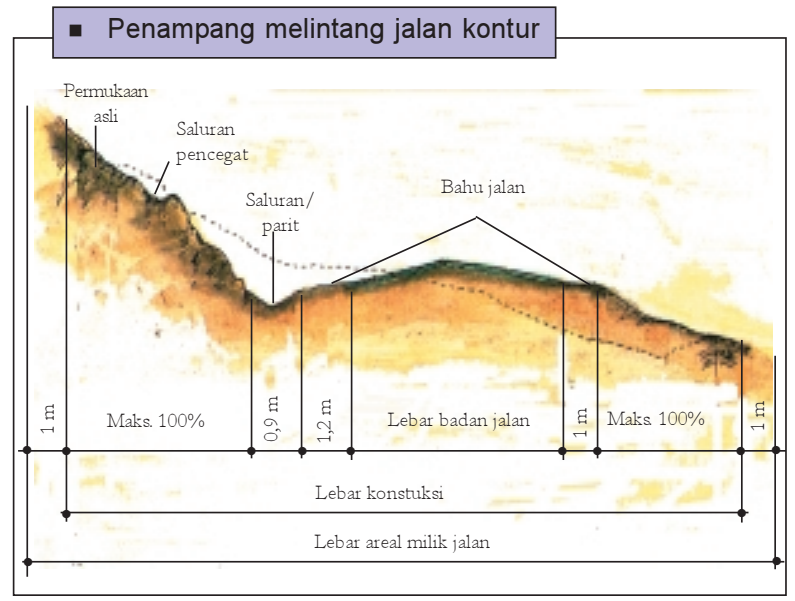

1. Kemiringan jalan sampai dengan $20 \%$ untuk seksi jalan yang pendek (maksiimum $500 \mathrm{~m}$ ) dapat diterima bila mengurangi kerusakan/ gangguan tanah

2. Tiap dua seksi jalan yang mempunyai kemiringan maksimum absolut harus dipisahkan dengan jalan yang datar atau berkemiringan ringan sepanjang 100 meter 
- Spesifikasi kemiringan jalan

\begin{tabular}{|c|c|c|c|}
\hline Kelas Jalan & $\begin{array}{c}\text { Kemiringan } \\
\text { Maksimum } \\
\text { yang Dijinkan } \\
(\%)\end{array}$ & $\begin{array}{c}\text { Kemiringan } \\
\text { Maksimum } \\
\text { yang Disukai } \\
(\%)\end{array}$ & $\begin{array}{c}\text { Seksi Panjang Jalan } \\
\text { Maksimum pada } \\
\text { Kemiringan Maksimum } \\
(\mathrm{m})\end{array}$ \\
\hline Jalan utama & 10 & 8 & 1000 \\
\hline Jalan cabang & 15 & 10 & 750 \\
\hline Jalan ranting & 18 & 12 & 600 \\
\hline
\end{tabular}

\section{Spesifikasi lebar jalan}

\begin{tabular}{|l|c|c|}
\cline { 2 - 3 } \multicolumn{1}{c|}{} & \multicolumn{2}{c|}{ Lebar Jalan Maksimum } \\
\cline { 2 - 3 } \multicolumn{1}{c|}{} & $\begin{array}{l}\text { Permukaan } \\
\text { Diperkeras }(\mathrm{m})\end{array}$ & $\begin{array}{l}\text { Permukaan Tanah Liat } \\
\text { Dipadatkan }(\mathrm{m})\end{array}$ \\
\hline Jalan utama (2 arah) & 10,0 & 15,0 \\
\hline Jalan utama (1 arah) & 6,3 & 11,0 \\
\hline Jalan cabang & 6,0 & 7,3 \\
\hline Jalan ranting & 5,0 & 6,0 \\
\hline
\end{tabular}


- Spesifikasi tikungan jalan

\begin{tabular}{|c|c|}
\hline $\begin{array}{c}\text { Jari-jari } \\
(\mathrm{m})\end{array}$ & $\begin{array}{c}\text { Pelebaran } \\
\text { Tikungan }(\mathrm{m})\end{array}$ \\
\hline 25 & 1,65 \\
\hline 30 & 1,20 \\
\hline 40 & 0,95 \\
\hline 50 & 0,80 \\
\hline 60 & 0,70 \\
\hline
\end{tabular}

\begin{tabular}{|c|c|}
\hline $\begin{array}{c}\text { Jari-jari } \\
(\mathrm{m})\end{array}$ & $\begin{array}{c}\text { Pelebaran } \\
\text { Tikungan }(\mathrm{m})\end{array}$ \\
\hline 75 & 0,55 \\
\hline 100 & 0,40 \\
\hline 150 & 0,35 \\
\hline 200 & 0,20 \\
\hline
\end{tabular}

- Pelebaran tikungan jalan diperlukan agar trailer dapat jalan agak menepi

- Lebar pelebaran tikungan berdasarkan kendaraan dengan panjang seluruhnya $14 \mathrm{~m}$

- Tambahan lebar pelebaran diperlukan untuk tiap jalur jalan, misalnya jalan dua arah, tikungannya memerlukan lebar pelebaran tikungan 2 kali nilai yang terdapat dalam tabel di atas 
- Jari-jari belokan

\begin{tabular}{|l|c|c|c|}
\cline { 2 - 4 } \multicolumn{1}{c|}{} & \multicolumn{3}{c|}{ Desain Kecepatan } \\
\cline { 2 - 4 } \multicolumn{1}{c|}{} & $30 \mathrm{~km} / \mathrm{jam}$ & $50 \mathrm{~km} / \mathrm{jam}$ & $80 \mathrm{~km} / \mathrm{jam}$ \\
\hline $\begin{array}{l}\text { Jari-jari minimum (memerlukan } \\
\text { rambu-rambu) }\end{array}$ & $25 \mathrm{~m}$ & $30 \mathrm{~m}$ & $55 \mathrm{~m}$ \\
\hline Jari-jari minimum yang disukai & $35 \mathrm{~m}$ & $75 \mathrm{~m}$ & $140 \mathrm{~m}$ \\
\hline $\begin{array}{l}\text { Jarak pandang minimum yang } \\
\text { diperlukan }\end{array}$ & $30 \mathrm{~m}$ & $64 \mathrm{~m}$ & $120 \mathrm{~m}$ \\
\hline Jarak temu pandang & $50 \mathrm{~m}$ & $100 \mathrm{~m}$ & $220 \mathrm{~m}$ \\
\hline
\end{tabular}

- Jari-jari minimum belokan berhubungan dengan jarak pandang dan kecepatan kendaraan yang melewati jalan tersebut

\begin{tabular}{|c|c|c|}
\hline \multicolumn{2}{|c|}{ - Jarak saluran drainase } & \\
\hline & \multicolumn{2}{|c|}{ Jarak Saluran Maksimal (m) } \\
\hline Kemiringan Jalan (\%) & Tanah Labil & Tanah Stabil \\
\hline $0-15$ & 40 & 60 \\
\hline $16-20$ & 20 & 40 \\
\hline $21-25$ & 10 & 20 \\
\hline
\end{tabular}

- Semua saluran drainase jalan untuk meminimalkan produksi sedimen

- Saluran drainase harus dibuat sebagai berikut :

* Pada perubahan kemiringan

* Pada jarak 50 m dari penyeberangan sungai/kali

* Saluran tambahan agar memenuhi kebutuhan jarak maksimum 


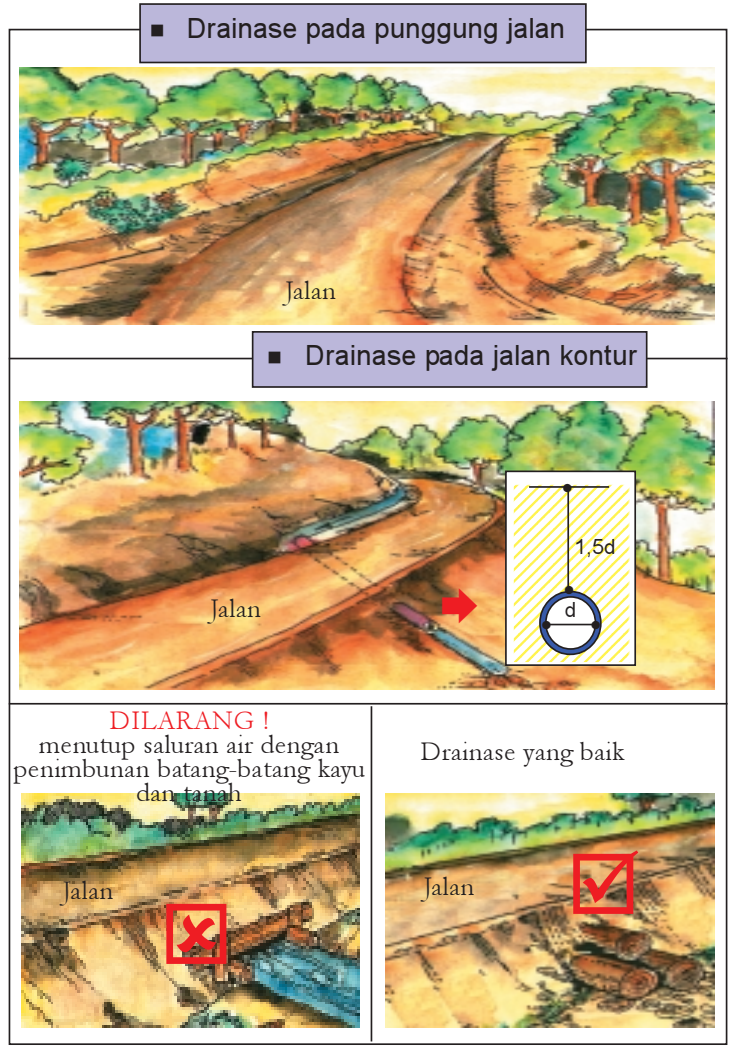




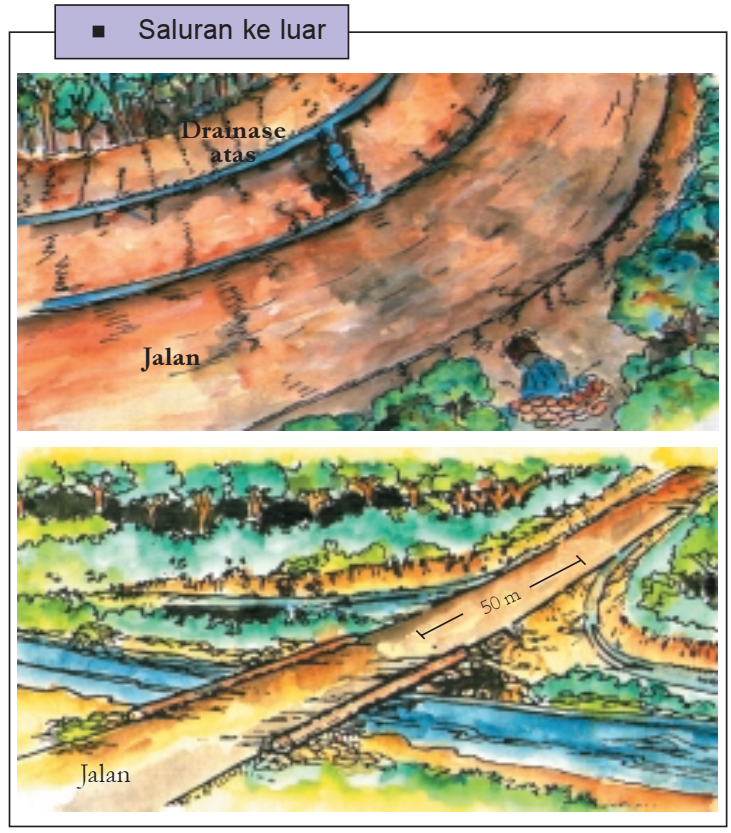

- Saluran drainase ke luar harus dibelokan ke semak/belukar di sekelilingnya, minimal $50 \mathrm{~m}$ sebelum bermuara di sungai 

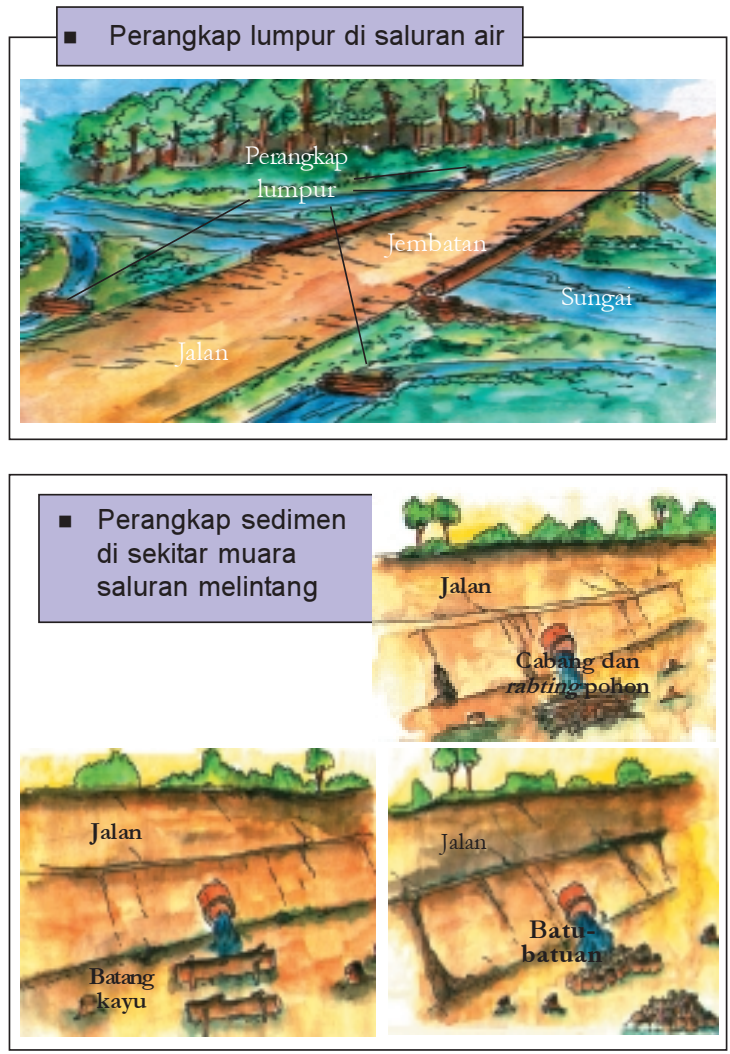
Usaha meminimalkan erosi pada tebing jalan
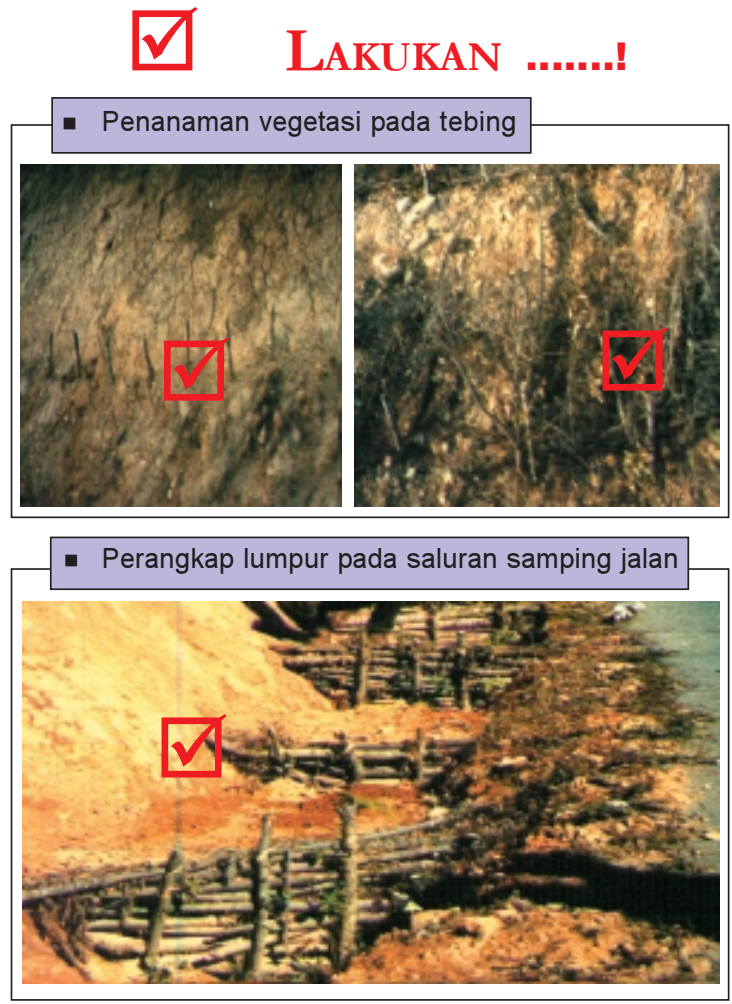
- Pembuatan jalan

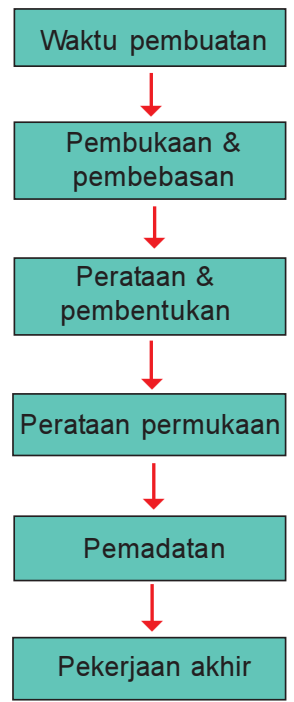




\section{Waktu pembuatan}

Pembuatan jalan dilaksanakan satu tahun sebelum pemanenan kayu dan tidak boleh dilakukan pada musim hujan

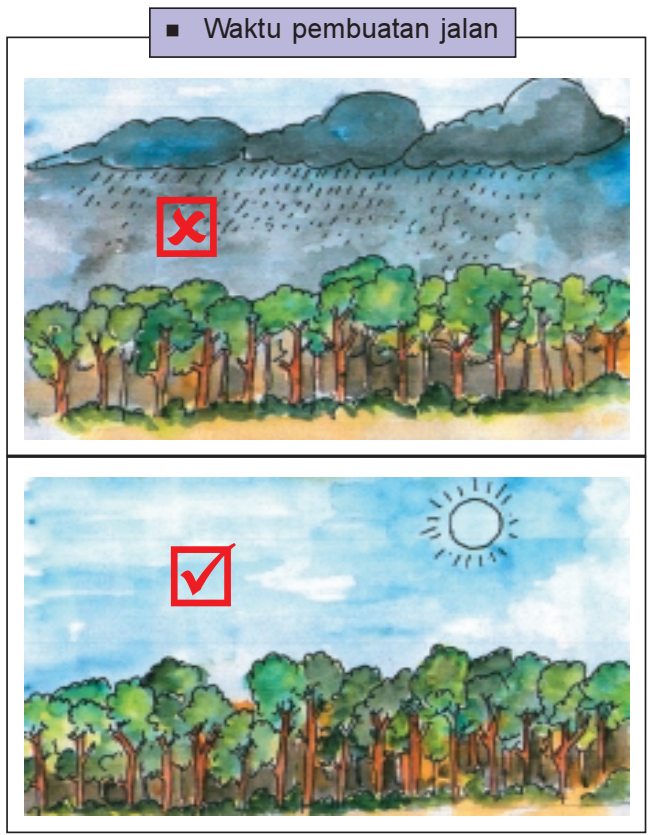




\section{Pembukaan dan pembebasan}

Menghilangkan pohon-pohon, tunggak-tunggak dan akar serta penghalang-penghalang lainnya dari areal konstruksi jalan.
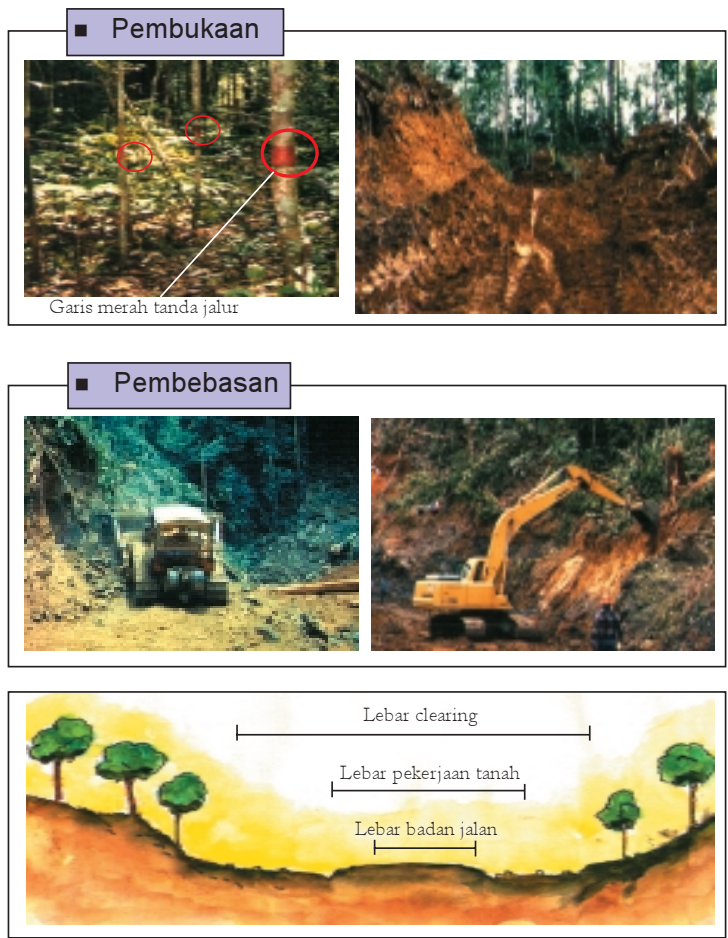


\section{Perataan dan pembentukan}

Perataan \& pembentukan merupakan kegiatan-kegiatan membangun jalan/pembentukan dan perataan badan jalan setelah opening dan clearing.

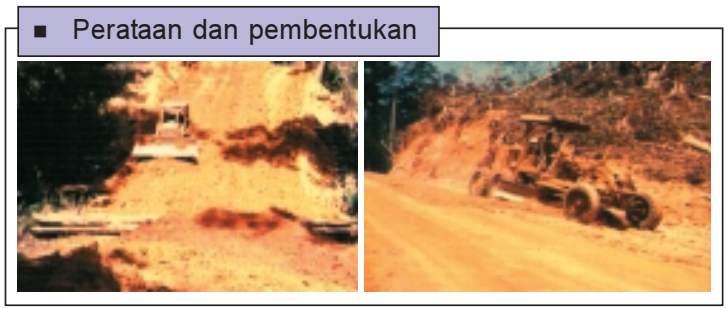

\section{Perataan permukaan}

Perataan permukaan merupakan kegiatan memberikan lapisan pengerasan pada badan jalan permanen. Umumnya menggunakan batuan, kerikil, pasir atau material lainnya yang diangkut dengan dump truk dari quari di sekitar lokasi jalan dan sebarkan di atas badan jalan dengan motorgrader.

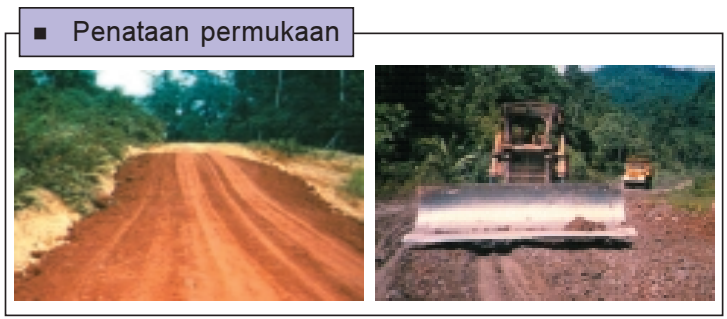




\section{Pemadatan}

Pemadatan merupakan kegiatan memadatkan dan menstabilkan badan jalan. Compacting dilakukan dengan roller vibrator/compactor.

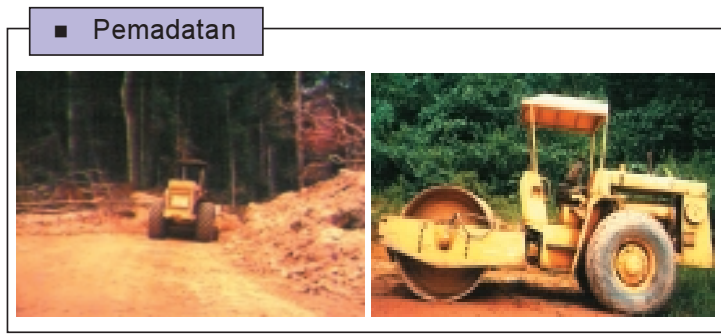

\section{Pekerjaan akhir}

Kegiatan tahap akhir pembuatan jalan yang meliputi penghalusan permukaan jalan, bahu jalan, jembatan, saluran air, gorong-gorong, dan lainnya. Penghalusan permukaan badan jalan, bahu jalan dan lainnya umumnya dilakukan dengan motor grader.

\section{- Pekerjaan akhir}
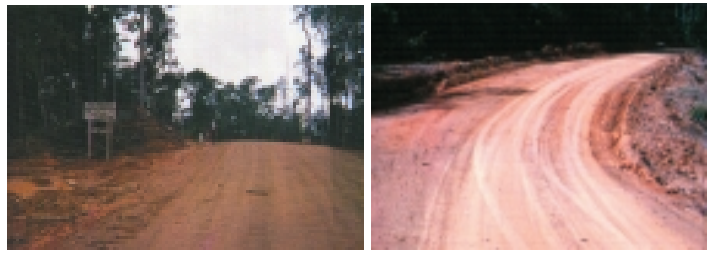


\section{- Penyeberangan sungai}
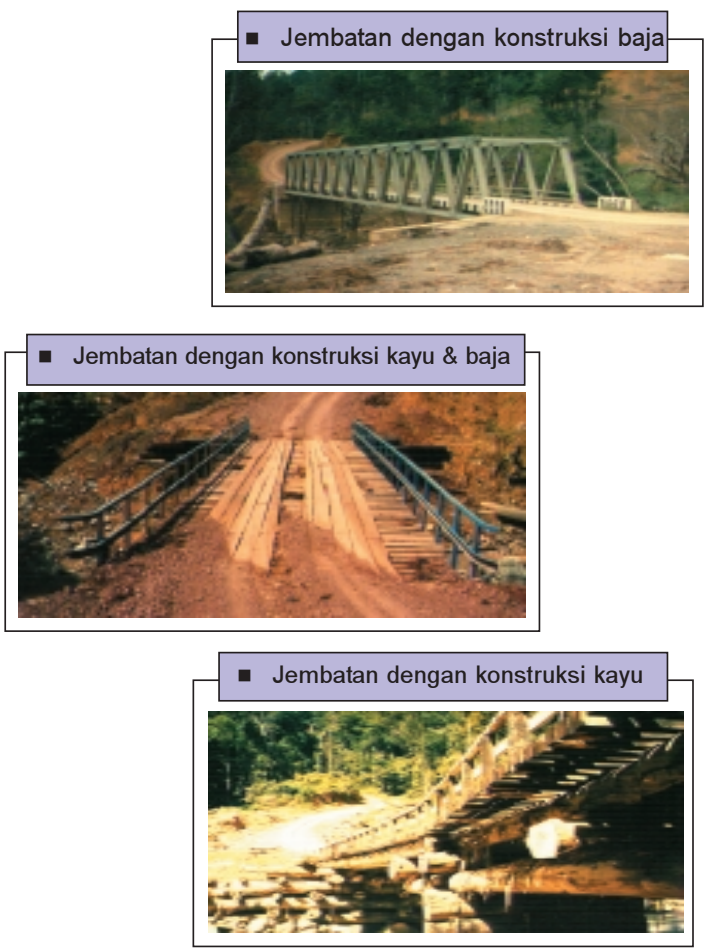


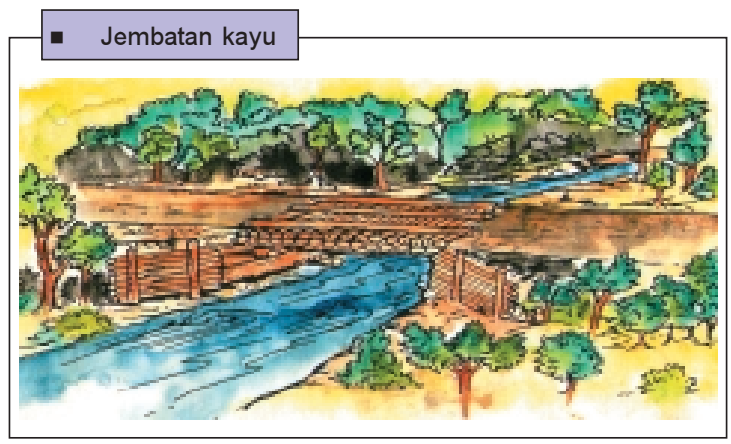

\begin{tabular}{|c|c|c|}
\hline \multicolumn{3}{|c|}{ Jenis kayu yang cocok untuk konstruksi jembatan } \\
\hline Di air tawar & Di air asin atau payau & Di atas air \\
\hline $\begin{array}{l}\text { Balau (Dipterocarpus } \\
\text { mundus V.SI.) }\end{array}$ & $\begin{array}{l}\text { Belian (Eusideroxylon } \\
\text { zwageri T.et.B) }\end{array}$ & $\begin{array}{l}\text { Balau (Diptercocarpus } \\
\text { mundus V.SI.) }\end{array}$ \\
\hline $\begin{array}{l}\text { Bangkirai (Shorea } \\
\text { laevis Ridl.) }\end{array}$ & Resak (Vatica spp.) & $\begin{array}{l}\text { Bangkirai (Shorea } \\
\text { laevis Ridl.) }\end{array}$ \\
\hline $\begin{array}{l}\text { Belian (Eusideroxylon } \\
\text { zwageri T.et.B) }\end{array}$ & Keranji (Dalium spp.) & $\begin{array}{l}\text { Belian (Eusideroxylon } \\
\text { zwageri T.et.B) }\end{array}$ \\
\hline Chengal (Hopea spp.) & - & Chengal (Hopea spp.) \\
\hline $\begin{array}{l}\text { Giam (Vatica } \\
\text { flavovirens V.SI) }\end{array}$ & - & $\begin{array}{l}\text { Giam (Vatica } \\
\text { flavovirens V.SI) }\end{array}$ \\
\hline Keranji (Dialium spp.) & - & Keranji (Dialium spp.) \\
\hline- & - & $\begin{array}{l}\text { Kempas (Koompassia } \\
\text { malaccensis Maing) }\end{array}$ \\
\hline- & - & $\begin{array}{l}\text { Merbau (Intsia bijuga } \\
(\text { Colebr. }))\end{array}$ \\
\hline
\end{tabular}



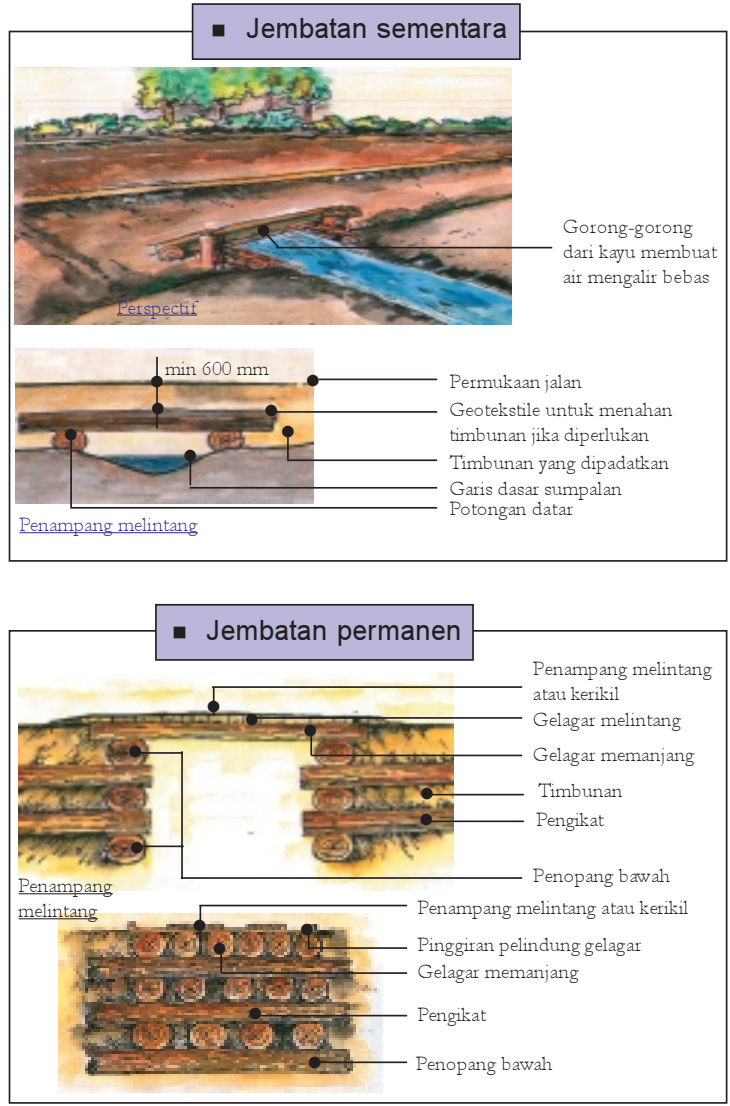


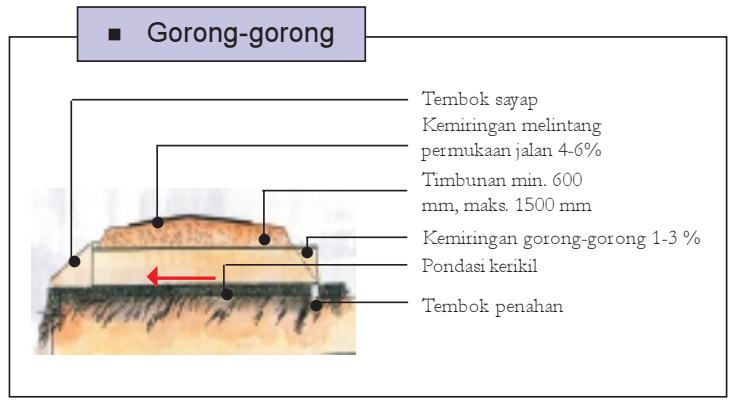


Persiapan Lapangan

Sebelum Pemanenan

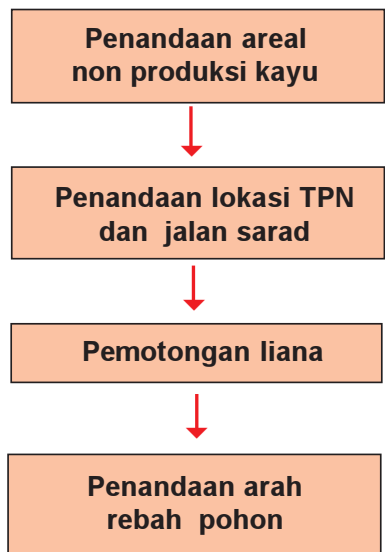




\section{- Penandaan areal non produksi kayu}

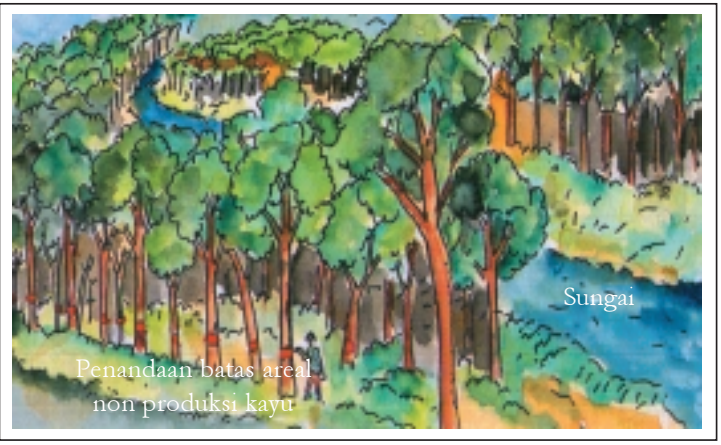

\begin{tabular}{|ll|}
\hline Kategori & Penandaan daerah penyangga \\
\hline $\begin{array}{l}\text { Zona } \\
\text { penyangga }\end{array}$ & $\begin{array}{l}\text { Penandaan batas pinggir dengan sebuah } \\
\text { "huruf T terbalik" pada sisi menghadap ke } \\
\text { areal pemanenan }\end{array}$ \\
\hline
\end{tabular}




\section{- Penandaan lokasi TPN dan jalan sarad}

\begin{tabular}{|l|l|}
\hline \multicolumn{2}{|c|}{ Penandaan jalan sarad } \\
$\begin{array}{l}\text { Kategori } \\
\text { Jalan sarad } \\
\text { utama }\end{array}$ & $\begin{array}{l}\text { Penandaan as jalan sarad dengan 1 stip vertikal } \\
\text { setinggi mungkin pada muka dan belakang } \\
\text { pohon. Interval jarak pohon yang ditandai } \pm 10 \mathrm{~m}\end{array}$ \\
\hline $\begin{array}{l}\text { Ujung jalan sarad } \\
\text { utama }\end{array}$ & $\begin{array}{l}\text { Ditandai dengan } 2 \text { stip paralel setinggi mungkin } \\
\text { menghadap ke jalan sarad }\end{array}$ \\
\hline $\begin{array}{l}\text { Jalan sarad } \\
\text { cabang }\end{array}$ & $\begin{array}{l}\text { Penandaan as jalan sarad dengan 1 strip } \\
\text { vertikal setinggi mungkin pada muka dan } \\
\text { belakang pohon. Interval jarak pohon yang } \\
\text { ditandai } \pm 10 \text { m }\end{array}$ \\
\hline $\begin{array}{l}\text { Jembatan } \\
\text { sementara }\end{array}$ & $\begin{array}{l}\text { Ditandai dengan huruf S pada pohon-pohon di } \\
\text { kedua sisi jembatan }\end{array}$ \\
\hline
\end{tabular}

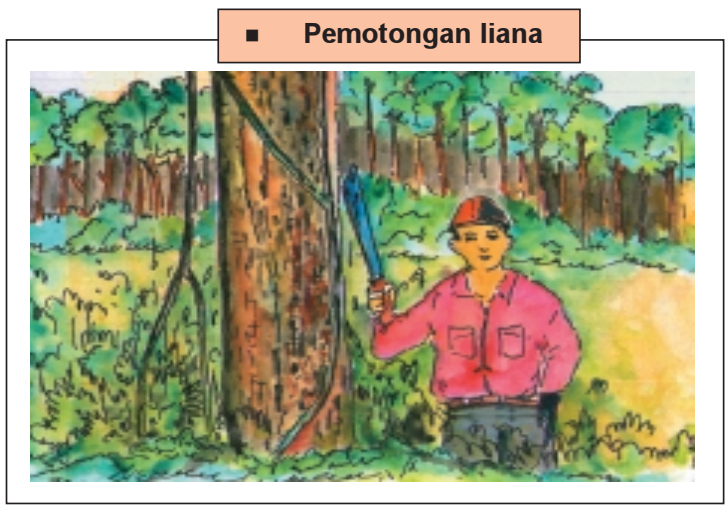


- Penandaan pohon yang ditebang dengan arah rebah pohon

Bagan pengambilan keputusan penandaan pohon

Diameter lebih besar dari batas diameter atau pohon mati, merana, rusak atau di areal yang akan dibuka untuk jalan/TPN menurut sistem silvikultur yang dipakai

YA

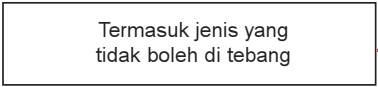

TIDAK

TIDAK

Jarak terhadap sungai

menurut spesifikasi RIL

TIDAK

YA

Pohon merupakan sumber biji menurut uraian sistem silvikultur yang dipakai

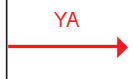

I

ه

$\dashv$

$\bar{\square}$

त

$\square$

$-$

$\dashv$

$m$

ए

工

Z

๑

\section{TIDAK}

PENANDAAN POHON YANG BOLEH DITEBANG 
- Penandaan arah rebah pohon

- Tanda arah rebah pohon

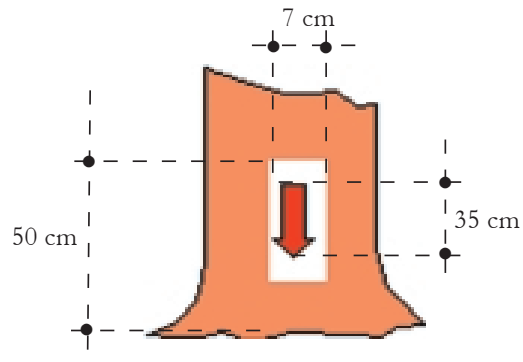




\section{OPERASI PEMANENAN KAYU}

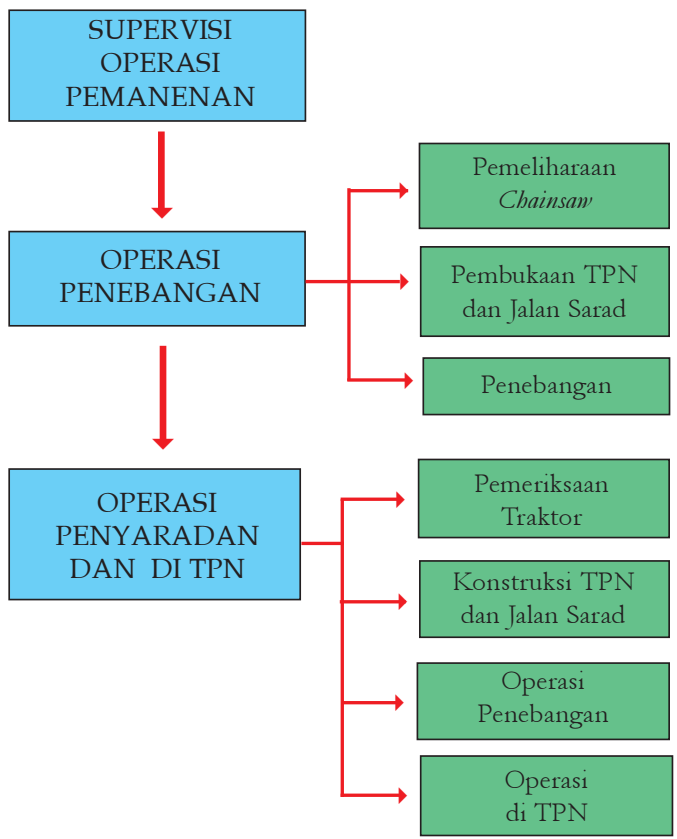




\section{SUPERVISI OPERASI PEMANENAN KAYU}

- Struktur Organisasi

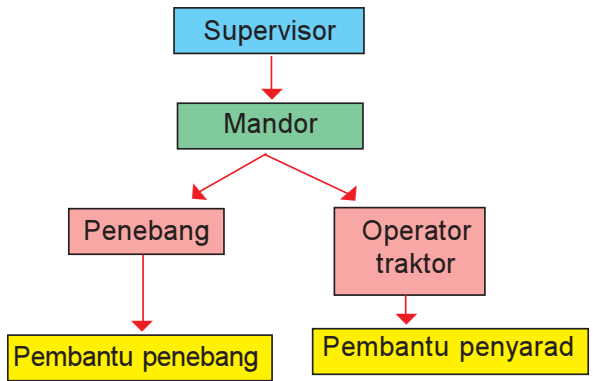

- Tugas dan Tanggung Jawab

\section{- Supervisor produksi}

- Terlibat langsung dalam pra-perencanaan pemanenan kayu

- Melatih dan mensosialisasikan staf terhadap peralatan operasi dan keselamatan kerja

- Mengkoordinasi operasi pemanenan kayu

- Mensupervisi langsung operasi pemanenan kayu

- Mengumpulkan dan melaporkan informasi yang dibutuhkan oleh perusahaan

- Mempercepat pertolongan pertama pada kecelakaan sebagaimana mestinya

- Mengevakuasi dengan cepat pekerja yang luka ke rumah sakit sebagaimana mestinya 
- Inspektur blok

- Langsung terlibat dalam pra-perencanaan pemanenan kayu

- Memantau kemajuan kegiatan penebangan dan penyaradan (termasuk memberikan petujuk)

- Memeriksa dan mengevaluasi hasil kegiatan penebangan, penyaradan dan kegiatan pasca panen

- Melaporkan hasil evaluasi dan penilaian per petak tebang kepada Manajer Kamp, Divisi Produksi Kayu dan Divisi Perencanaan Hutan

- Menghitung dan mempersiapkan usulan upah/ pembayaran berdasarkan tarif upah penebangan dan penyaradan, untuk dilaporkan kepada Manajer Kamp

- Mandor penebangan dan penyaradan

- Memastikan bahwa hanya pekerja-pekerja yang berwewenang dan terlatih yang mengoperasikan mesin-mesin dan peralatan

- Mengkoordinasikan, menyempurnakan dan memberikan petunjuk dalam pembuatan jalan sarad, operasi penebangan dan penyaradan

- Mengendalikan dan memantau proses produksi dalam rangka mendapatkan kualitas dan jumlah sesuai target

- Memastikan bahwa semua peralatan dan fasilitas betul-betul diinspeksi dan dipelihara dengan baik 
- Memelihara chainsaw agar selalu dalam kondisi operasi yang aman

- Bertanggungjawab atas kegiatan penebangan yang dilakukannya

- Menebang pohon sesuai dengan rencana pemanenan kayu atau arah rebah yang tepat

- Memotong batang pohon yang telah ditebang sesuai dengan aturan dan prosedur pembagian batang

- Membuka jalan sarad dan jalur winching

- Pembantu penebang

- Membantu mencari lokasi pohon yang akan ditebang

- Membantu memeriksa apakah semua pohon yang harus ditebang sudah ditebang

- Membuat jalur penyelamatan bagi penebang

- Membantu membersihkan cabang pohon dan pengukuran batang sebelum pemotongan batang

- Melekatkan/memakukan nomor pohon pada tunggak dan nomor pohon dan batang pada bontos kayu bulat

- Membawa perlengkapan peralatan chainsaw, alatalat pemeliharaan dan minyak pelumas

- Membawa air minum dan rantang makanan

- Membersihkan chainsaw dan alat-alat lain 
- Bertanggungjawab atas traktor dan perlengkapanya

- Membuat TPN dan jalan sarad

- Mengikuti standar teknis penyaradan sebagaimana yang direncanakan

- Melakukan usaha meminimalkan kerusakan lingkungan lebih lanjut terhadap tegakan tinggal dan lingkungan

- Bertanggungjawab atas kegiatan penyaradan yang dilakukannya

\section{Pembantu penyarad}

- Membantu operator traktor merawat traktor

- Bertanggungjawab atas kabel choker/hook

- Mencari batang kayu/log yang akan disarad

- Memasang kabel choker/hook pada batang kayu/ $\log$

- $\quad$ Memberi kode kepada operator traktor untuk mengambil posisi winching

- Menarik kabel winch dan memasangkannya pada kabel choker/hook

- Memberi kode kepada operator traktor bahwa winching dapat dimulai

- Membantu operator traktor dalam usaha meminimalkan kerusakan labih lanjut setelah pemanenan kayu 
- Informasikan dan diskusikan rencana dan pelaksanaan pemanenan kayu

Setiap pekerja yang terlibat harus tahu tugas dan tanggungjawabnya, prosedur dan standar kerja yang diharapkan

"Pertemuan Pagi Hari" :

Pertemuan mandor sarad/ tebang, operator chainsaw dan operator traktor

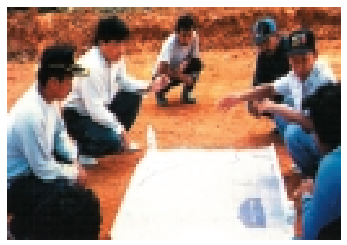

"Pertemuan Mingguan":

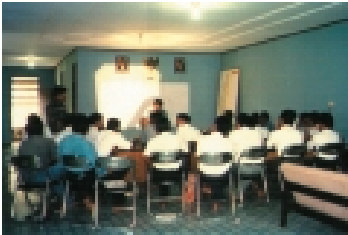

Pertemuan supervisor produksi, inspektur blok, mandor sarad/tebang, penebang dan operator traktor 


\section{OPERASI PENEBANGAN}
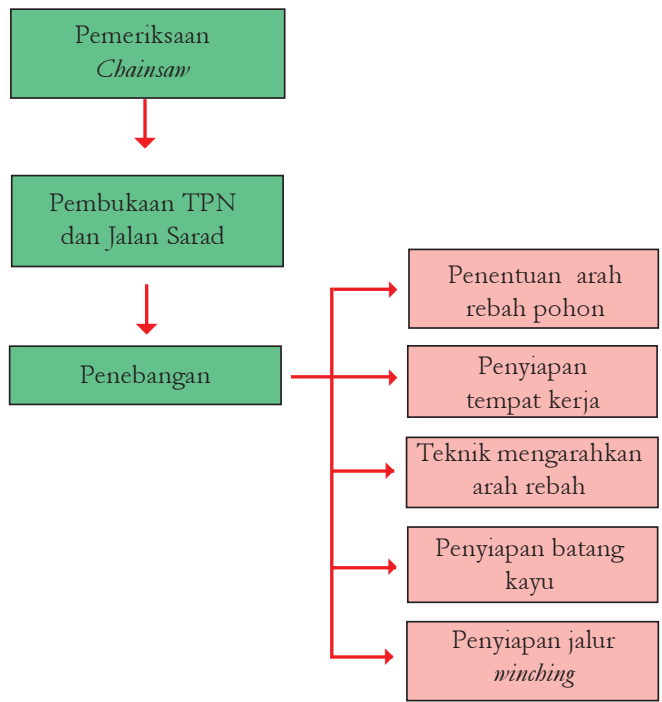


\section{Pemeriksaan Chainsaw}

Biasakanlah memeriksa chainsaw setiap sore hari ! Bagian-bagian yang diperiksa :

* Rantai gergaji

* Bilah gergaji

* Kopling

* Saringan minyak dan saringan bahan bakar

* Busi

* Sistem pembuangan asap

* Rem rantai dan pelindung pegangan depan
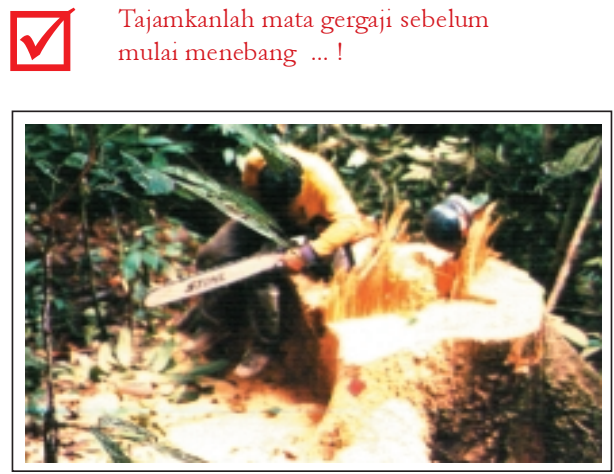


\section{Pembukaan TPN dan Jalan Sarad}

* Pembukaan TPN dan jalan sarad dilakukan sebelum penebangan dimulai

* Alat yang dipergunakan adalah rencana pemanenan kayu di atas peta dan di lapangan serta chainsaw

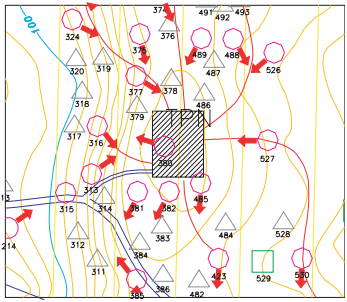

1. Peta TPN dan jaringan jalan sarad

2. Penebangan untuk membuka jalan sarad (Et-0)

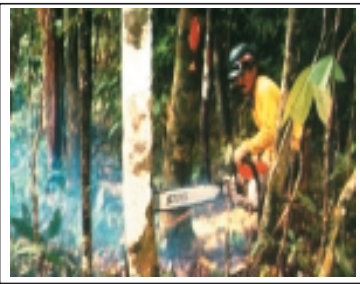

Et $-0=$ tahun waktu pemanenan; $(-)=$ tahun sebelum pemanenan 
1. Tim pembuka TPN dan jalan sarad terdiri dari seorang penebang dan seorang pembantu penebang

2. Penebang membuka TPN dan jalan sarad dengan menebang semua pohon $\varnothing \geq 15 \mathrm{~cm}$ yang berada di areal TPN dan pada rencana jalan sarad

3. Penebangan dimulai dari ujung salah satu cabang jalan sarad di dalam hutan menuju TPN dengan arah rebah menjauh dari TPN

4. Takik rebah dan takik balas dibuat serendah mungkin dengan arah rebah pohon sesuai dengan arah jalan sarad atau di atas jalan sarad 


\section{Penebangan}

\section{- Prosedur penebangan}

1. Penebangan dimulai sesuai dengan urutan atau pola penebangan yang telah direncanakan di atas peta

2. Pemeriksaan keadaan lokasi penebangan, penentuan arah rebah pohon, persiapan tempat kerja, pembuatan jalur penyelamatan dan pemberi peringatan

3. Pembuatan takik rebah dan takik balas pada tunggak serendah mungkin

4. Pembersihan batang dari cabang-cabang dan pemotongan tajuk pohon

5. Pembersihan batang dari banir pohon

6. Pengukuran dan pemotongan batang sesuai dengan permintaan perusahaan

7. Memasang nomor pohon pada tunggak dan pada ujung batang log

8. Membuka jalur winching

9. Menuju pohon lain yang akan ditebang

\section{HINDARKAN .....!}

- Pohon rebah memotong sungai atau masuk areal kawasan lindung

- Kerusakan pada pohon inti, permudaan dan pohon lindung 


\section{Pemilihan arah rebah}

\section{Arah rebah pohon}

Prosedur penentuan arah rebah pohon:

1. Arah rebah yang terbaik adalah yang mendekati atau menjauhi jalan sarad dengan membentuk sudut $30^{\circ}-45^{\circ}$ (pola sirip ikan) atau arah rebah dalam posisi sejajar di atas jalan sarad dengan arah berlawanan dengan arah penyaradan

2. Bila memungkinkan, arah rebah pohon diarahkan ke tempat kosong dan pada tajuk pohon yang sudah ditebang sebelumnya (maksimal 3)

3. Pada areal curam, arah rebah menyerong ke samping lereng (sepanjang kontur)

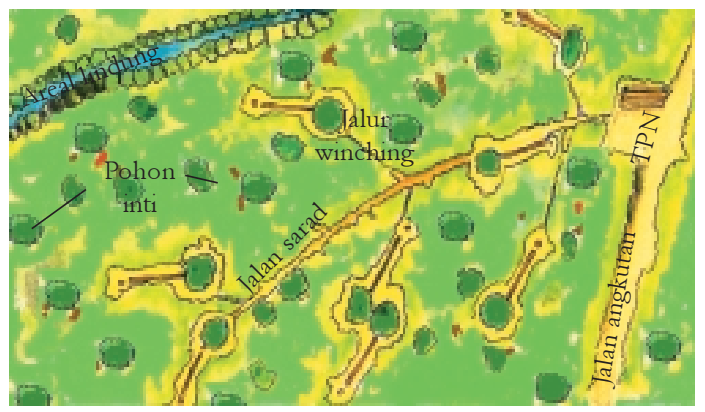




\section{Penyiapan tempat kerja}
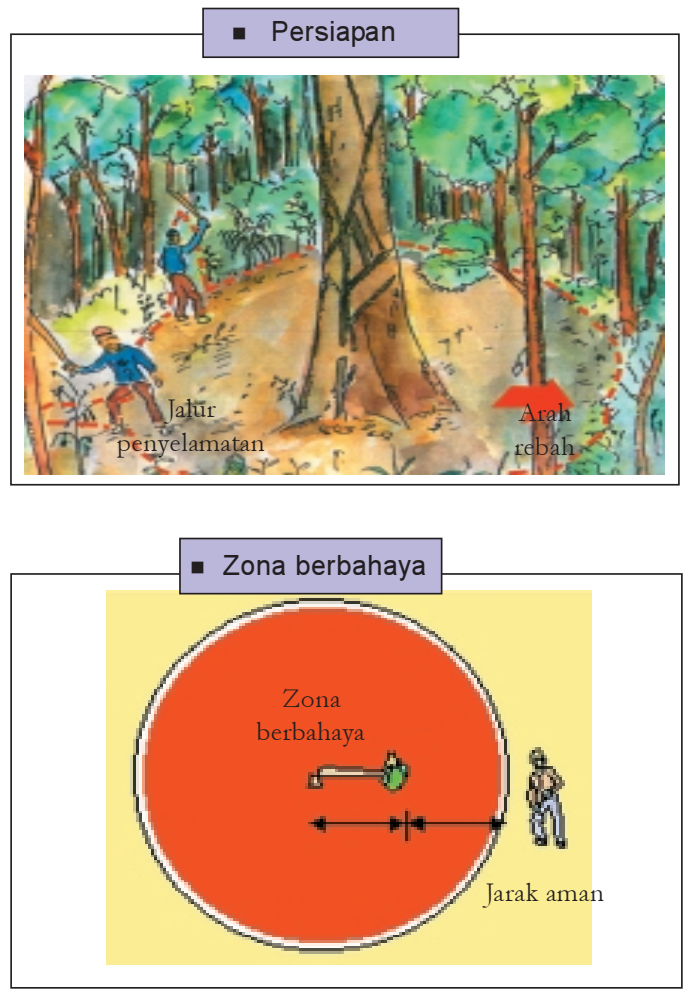
Teknik mengarahkan arah rebah

Pergunakanlah baji untuk membantu mengarahkan arah rebah

- Teknik penebangan pohon miring
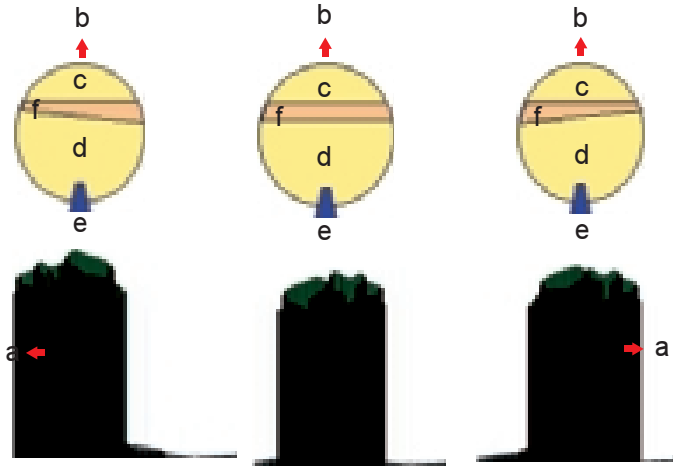
$\mathrm{a}=$ Arah miring pohon
$\mathrm{d}=$ Takik balas
$\mathrm{b}=$ Arah rebah
$\mathrm{e}=\mathrm{Baji}$
$\mathrm{c}=$ Takik rebah
$\mathrm{f}=$ Engsel

Penebangan terarah pohon miring

- Takik rebah dibuat sesuai dengan arah rebah yang diinginkan

- Buat engsel asimetris dimana lebar kayu engsel lebih sempit disisi arah miring pohon

- Gunakan baji untuk membantu mengarahkan arah rebah pohon 
- Cara membuat takik rebah, takik balas dan engsel
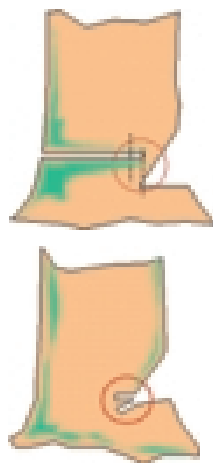

冈 Salah

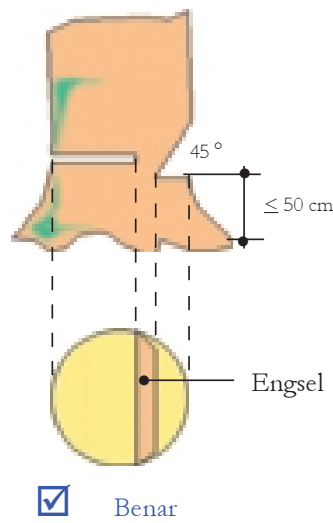

- Teknik memotong takik balas

- Pohon kecil

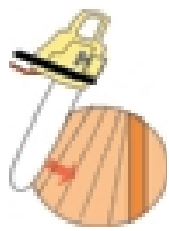

- Pohon besar

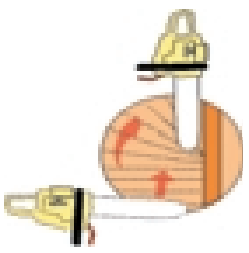




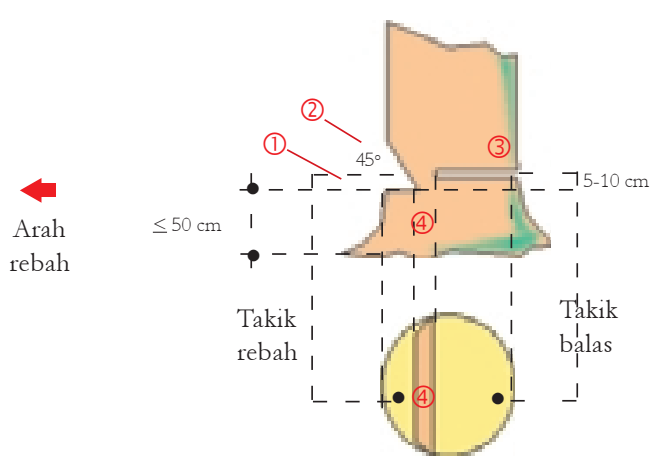

Tahapan kerja :

(1) Buat potongan datar sedalam 1/4-1/3 $\phi$ pohon pada ketinggian maksimum $50 \mathrm{~cm}$

(2) Buat potongan atap/miring dengan sudut $45^{\circ}$ terhadap potongan datar

(3) Buat potongan datar dari belakang takik rebah setinggi $5-10 \mathrm{~cm}$ dari potongan datar takik rebah

(4) Tinggalkan engsel selebar $1 / 10-1 / 6 \phi$ pohon 
- Teknik menebang pohon besar

1. Buat takik rebah

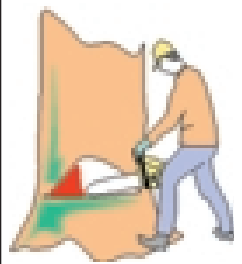

3. Buat takik balas setinggi $10-20 \mathrm{~cm}$ di atas takik rebah

2. Buat lubang pusat
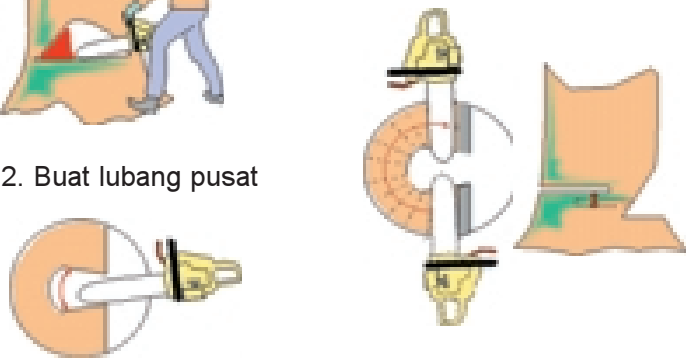

- Teknik memanfaatkan batang berbanir

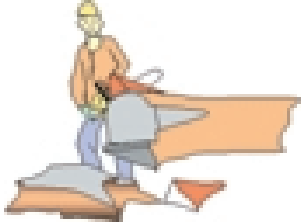

Merimbas banir setelah pohon rebah

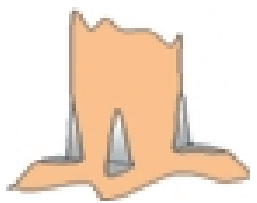

Banir besar dipotong sebelum penebengan 
- Teknik menebang pohon miring

Pohon kecil

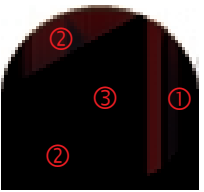

Tahapan kerja :

1. Buat takik rebah

2. Buat takik balas dengan pemotongan dari sisi kiri dan kanan takik balas

3. Potong dari depan takik balas

\section{Pohon besar}

(4)

(3)

(2)
(3)

(4)

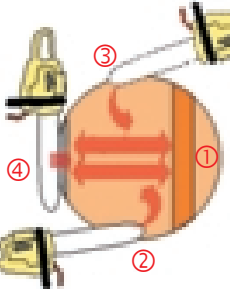

Arah rebah

\section{(1)}

Tahapan kerja :

1. Buat takik rebah

2. Buat takik balas dengan cara menusuk dari samping kiri takik balas

3. Pemotongan dengan cara menusuk dari samping kanan takik balas

4. Pemotongan takik balas dari depan takik balas 


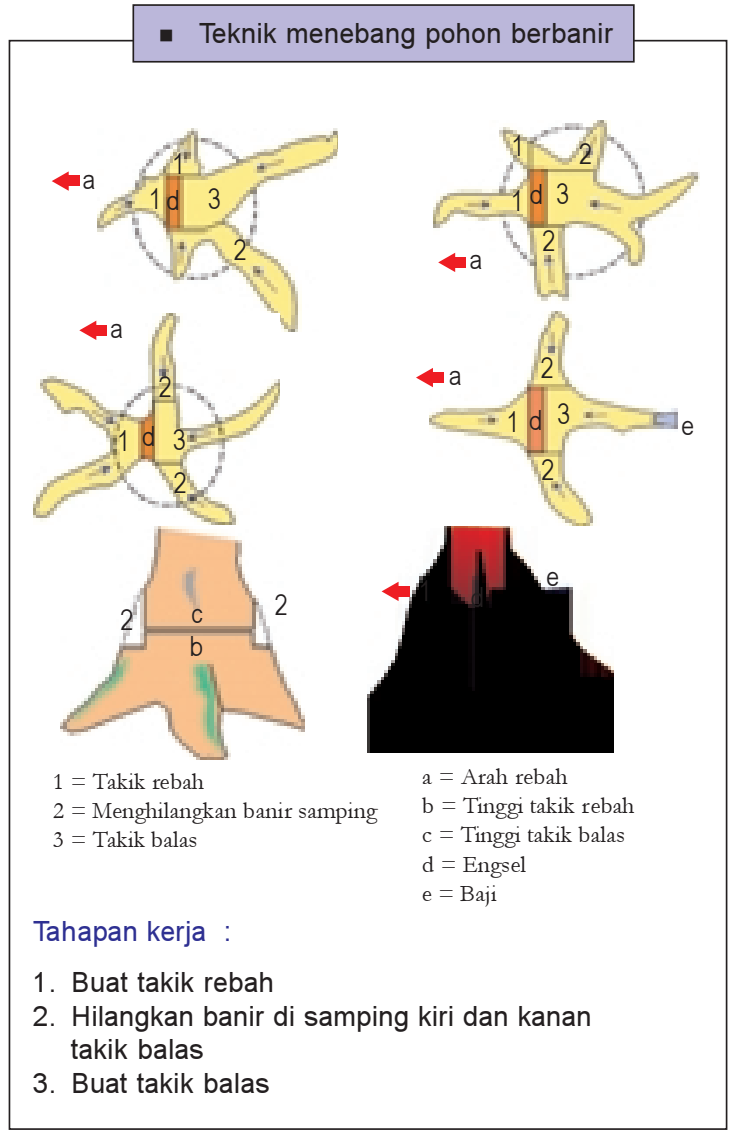




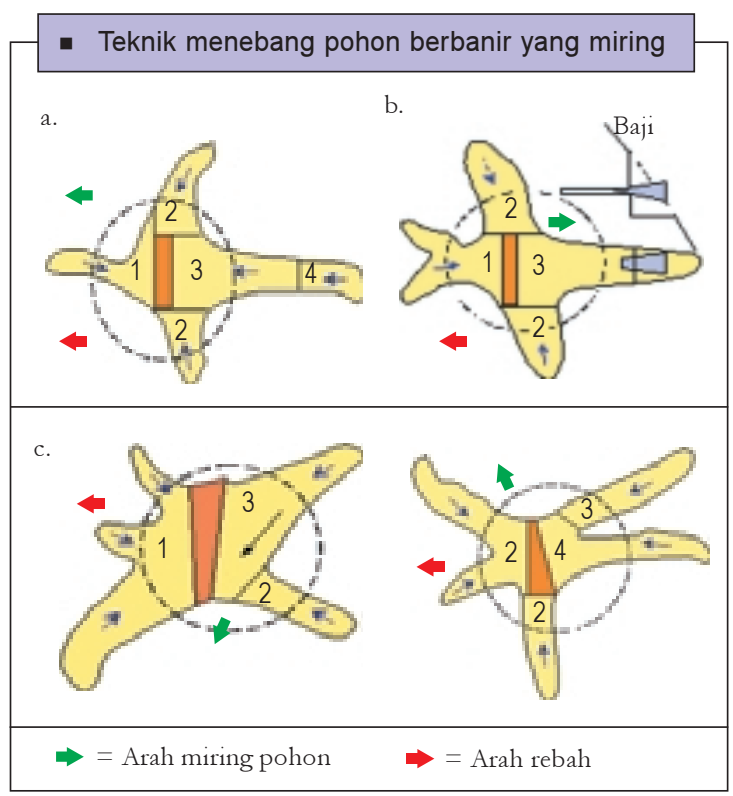

\section{a. Arah rebah sama dengan arah miring pohon \\ b. Arah rebah berlawanan dengan arah miring pohon \\ c. Arah rebah menyerong ke kiri atau ke kanan arah miring pohon}

Bilangan 1, 2, 3, 4 menunjukkan urutan/tahapan kerja (membuat takik rebah, menghilangkan banir, pembuatan takik balas dan memotong banir penahan) 
Teknik pemotongan batang

- Pemotongan batang

1. Pengukuran dan pembagian batang harus dilakukan sebelum pemotongan batang. Pemotongan batang harus tegak lurus sumbu batang, tidak boleh miring melebihi $10^{\circ}$ terhadap sumbu vertikal

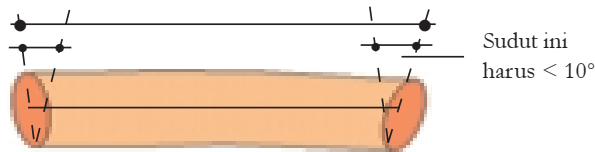

2. Pemotongan batang yang ada tegangan

a. Potong bagian yang mengalami tekanan, lalu

b. Potong bagian yang mengalami regangan

a.

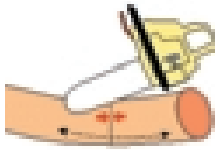

a.

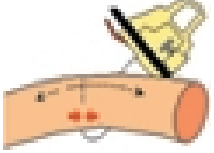

b.

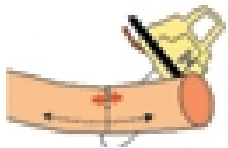

b.

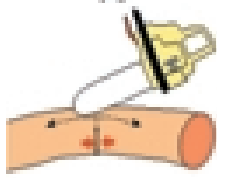

3. Teknik memotong batang
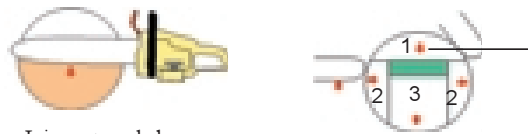

Zona tegangan

Irisan tegak lurus 


\section{Penyiapan jalur winching}

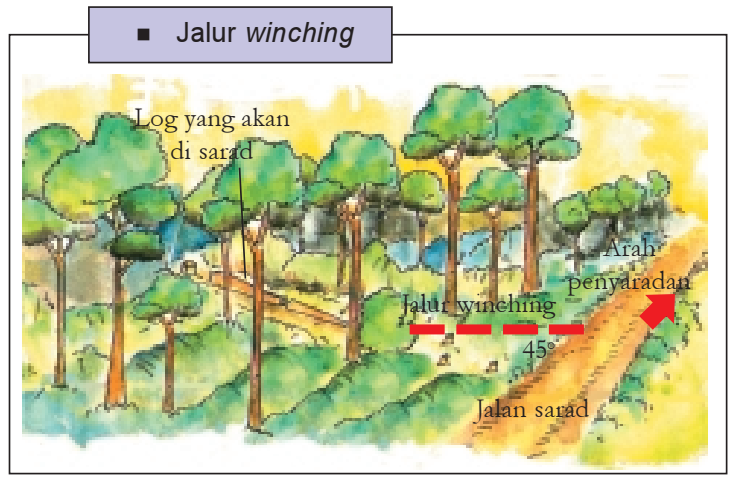




\section{OPERASI PENYARADAN DAN OPERASI DI TPN}

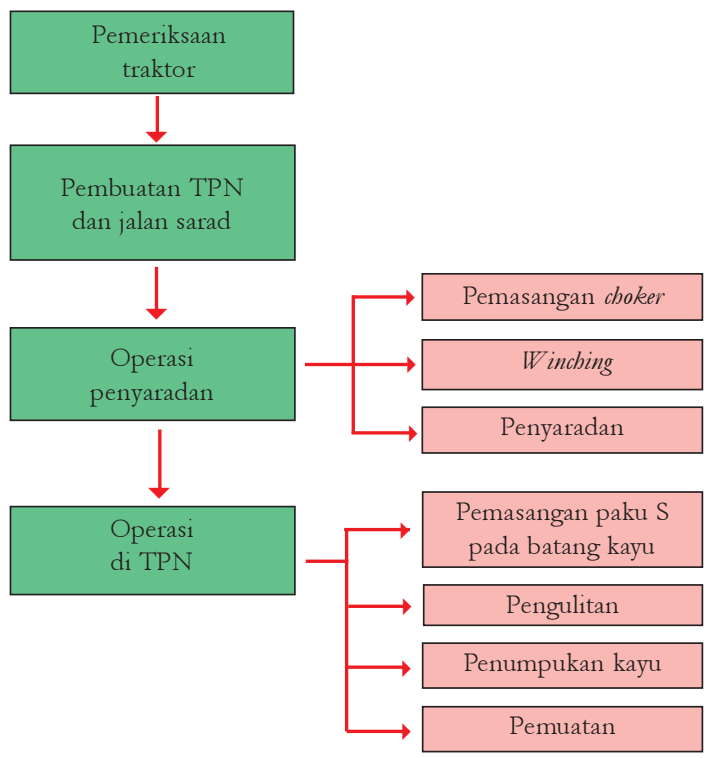




\section{Pemeriksaan Traktor}

Pemeliharaan traktor harus dilakukan oleh operator traktor dan pembantu setiap pagi

sebelum operasi dan pada sore hari

- Bagian-bagian yang harus diperiksa

Sebelum operasi :

* Periksa minyak pelumas pada :

- Mesin

- Kemudi

- Kopling

* Periksa air radiator

* Periksa kemungkinan kendor pada :

* Periksa semua ganjal :

- Mesin

- Radiator

- transmisi

- Transfer

- Semua roda dan ban

- Semua as baling-baling

- Semua per / baut U

- Battery

Selama pemanasan :

* Periksa fungsi dari :

- Pengukur suhu air

- Pengukur tekanan minyak

- Pengukur tekanan udara

- Amper meter

* Periksa asap mesin

* Periksa fungsi kerja dari :

- Rem kaki

- Rem tangan

- Kopling

- Kemudi

* Periksa bunyi mesin

* Buang air dalam tangki angin

* Periksa semua fungsi transmisi dan transfer 


\section{Setelah operasi :}

- Isi tangki bahan bakar

- Parkir traktor di tempat parkir yang datar

- Matikan mesin setelah 5 menit diam

- Bersihkan ruangan dalam kabin

- Bersihkan kotoran di sela-sela roda dan ban

- Bersihkan kotoran pada lampu dan kaca

- Kunci pintu kabin

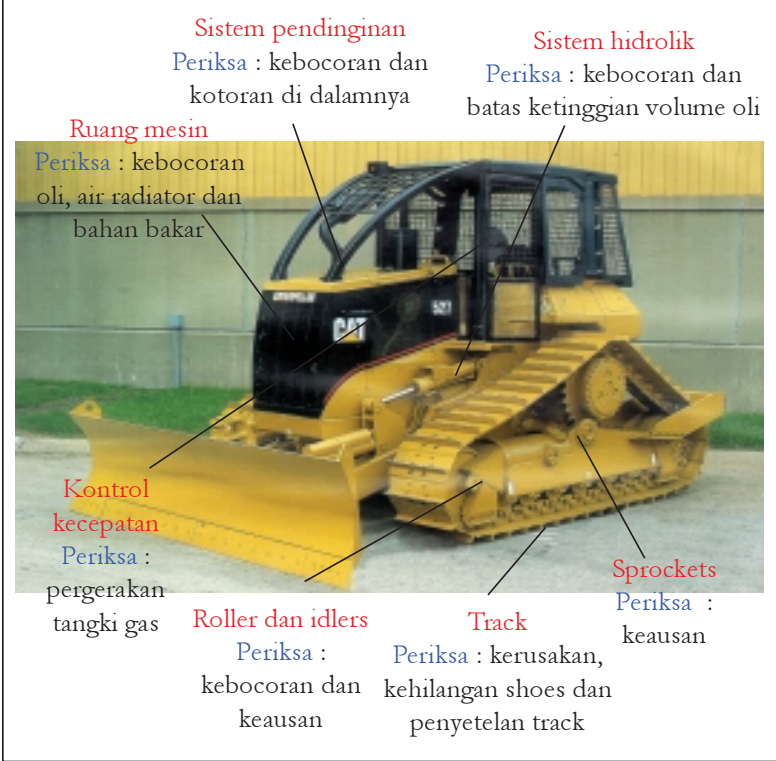




\section{Pembuatan TPN dan Jalan Sarad}

- Pembuatan TPN

Serasah dan lapisan atas tanah
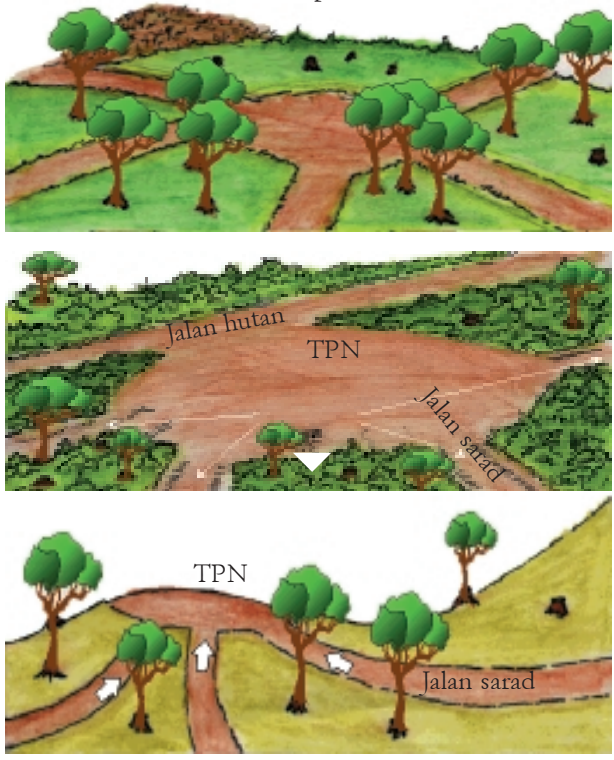

- Ukuran TPN : $900 \mathrm{~m}^{2}$

- Saluran drainase harus dibuat dan mengalir ke areal stabil yang bervegetasi 


\section{Pembuatan jalan sarad}

Tahapan pembuatan jalan sarad :

Et-1*

Et-1

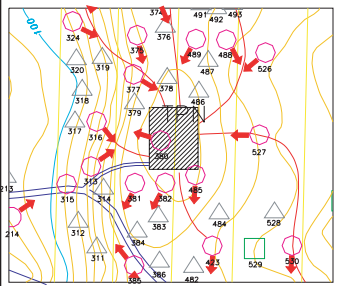

Peta jaringan jalan sarad
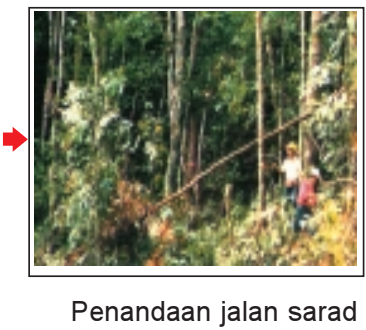

Et-0

$\checkmark$ Et-0

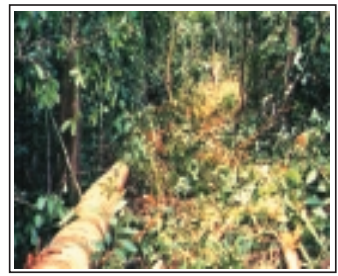

Konstruksi jalan sarad

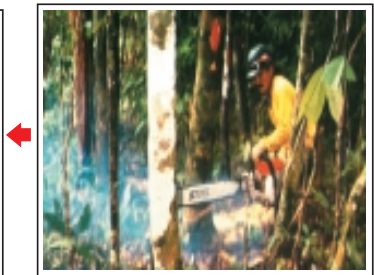

Pembukaan jalan sarad

* Et-0 = tahun waktu pemanenan;

$(-)=$ tahun sebelum pemanenan 


\section{Tahapan pembuatan jalan sarad}

- Pembuatan jalan sarad dimulai setelah pembukaan jalan sarad dan penebangan selesai dan dilakukan oleh tim penyarad dengan menggunakan traktor

- Pembuatan jalan sarad diselesaikan dengan menarik keluar pohon-pohon yang sudah ditebang, perbaikan dan perataan permukaan jalan sarad

- Hindarkan sedapat mungkin gali timbun dalam pembuatan jalan sarad

- Kayu kecil dan cabang-cabang yang tidak dikeluarkan, dimanfaatkan untuk melindungi permukaan jalan sarad

\section{Operasi Penyaradan}

- Prosedur penyaradan

- Operasi penyaradan dimulai setelah pembuatan jalan sarad selesai

- Penyaradan dimulai dari batang kayu/log terdekat

- Pembantu memasang kabel choker/hook pada log

- Pembantu memberi tanda kepada operator traktor untuk mengambil posisi winching

- Pembantu menarik kabel winch dan mengaitkannya pada kabel choker/hook pada log yang akan diwinch

- Pembantu pindah ke tempat yang aman dan memberi kode bahwa winching dapat dimulai

- Pada waktu winching, traktor harus pada posisi diam dan tetap berada di jalan sarad

- Setelah winching selesai, muatan/log disarad di jalan sarad ke TPN

- Pembantu mencari log lain dengan bantuan Peta Pemanenan Kayu 


\section{HINDARKAN ...!}

1. Melakukan penyaradan pada waktu hujan dan tanah masih basah

2. Traktor penyarad bergerak ke luar jalan sarad

3. Pada waktu penyaradan, pisau traktor menyentuh /mengupas tanah dan melukai pohon di kiri-kanan jalan sarad

4. Traktor masuk ke dalam kawasan lindung

- Perlengkapan penyaradan

- Peta pemanenan kayu dari tim penebang

- Traktor penyarad lengkap dengan derek, blade $<4 \mathrm{~m}$

- 2-4 buah kabel choker/hook

- 1 buah block

- 2 pasang sepatu lapangan

- 2 buah topi pengaman

- 2 pasang sarung tangan

- 2 stel baju kerja lapangan

- 2 buah rantang dan 1 buah galon air isi 5 liter 
Pemasangan choker
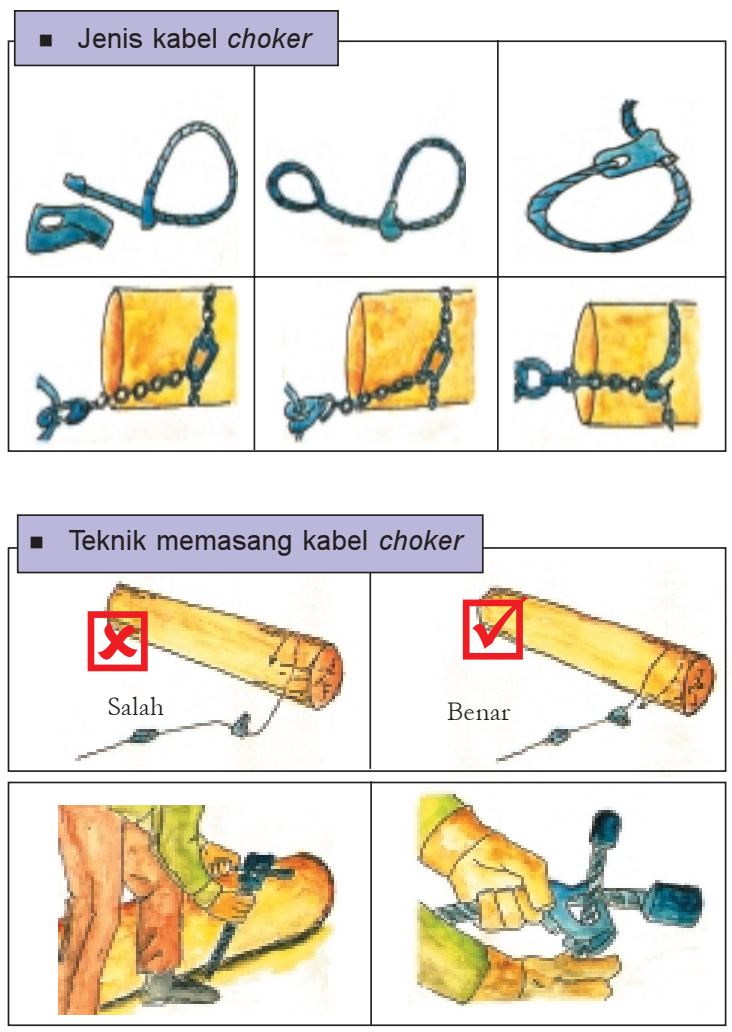


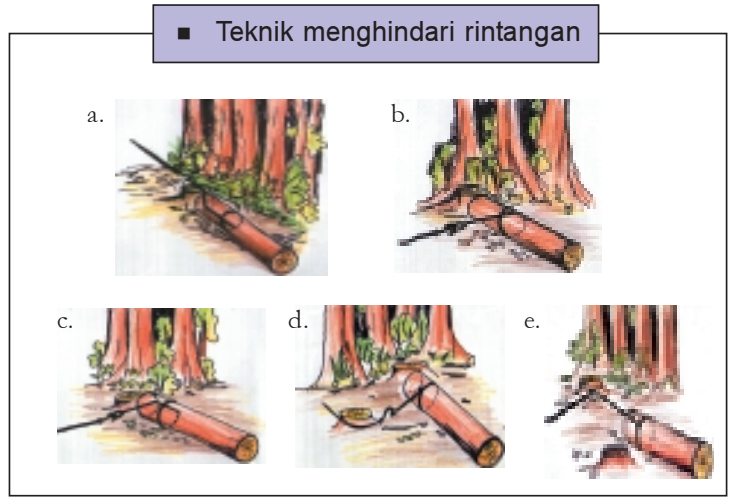

Winching

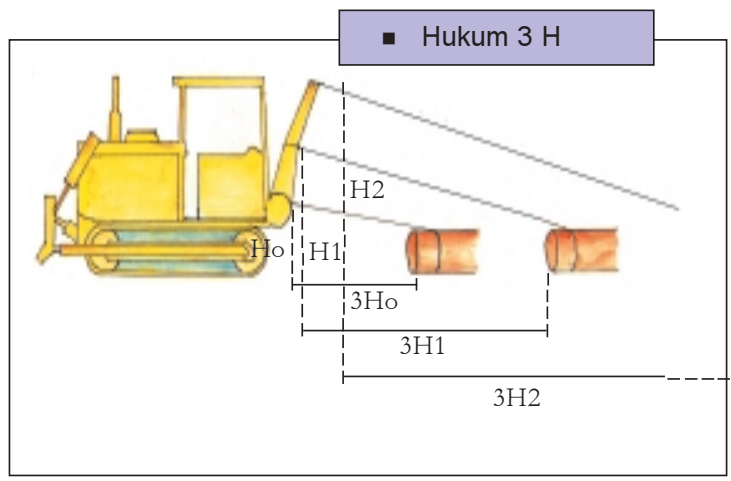


- Teknik winching berantai

1. Traktor berjalan menuruni lereng, kemudian menarik log (posisi traktor diam)

2. Setelah log yang ditarik berada dekat traktor, kabel winch dikendurkan
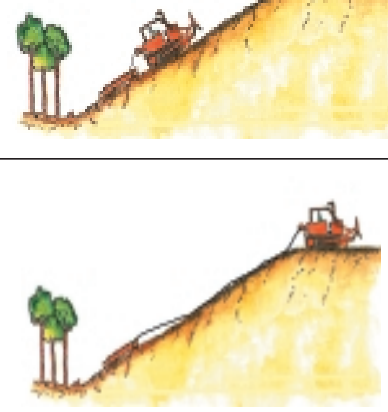

3. Traktor bergerak menuju TPN (tidak melakukan kerja tarik)

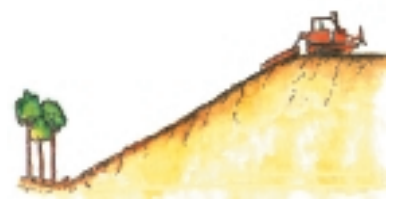

4. Setelah traktor sampai di TPN, winching dilakukan kembali sampai log tiba di TPN 


\section{Penyaradan}

\section{- Teknik menyarad untuk meminimalkan kerusakan}

- Angkat pisau traktor sewaktu penyaradan

- Pergunakan lengkungannya (arch) untuk menaikan ujung kayu yang sedang disarad

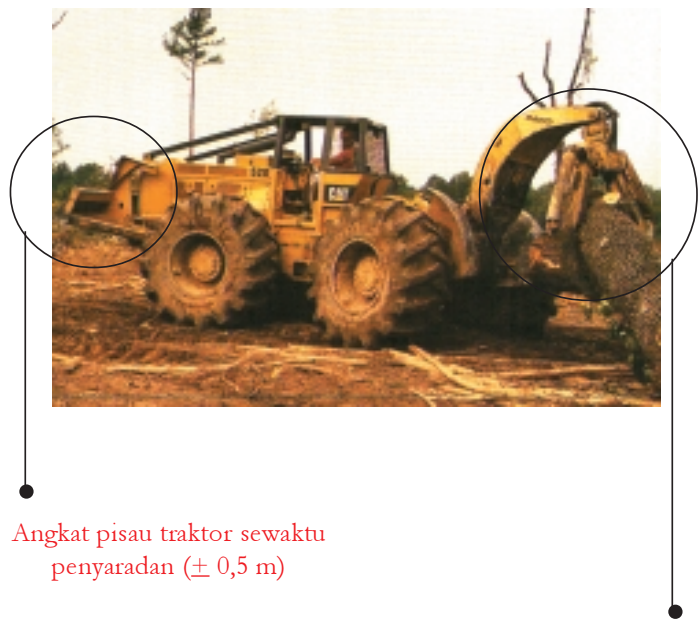

Pergunakan "arch" untuk menaikan ujung kayu yang sedang disarad 


\section{- Kode dalam penyaradan}

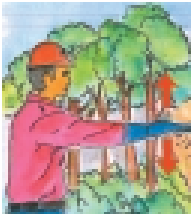

a. Kendurkan kabel winch

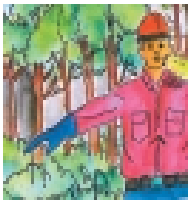

d. Traktor stop!

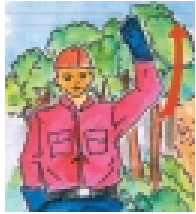

b. Winching

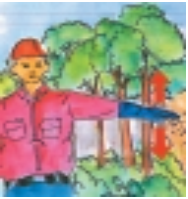

e. Traktor boleh mulai winching

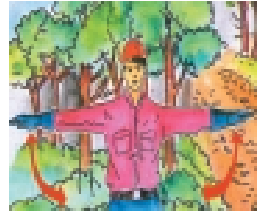

c. Stop minching dan tahan

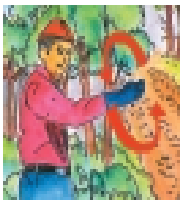

f. Traktor putar mundur !

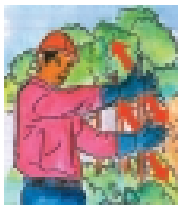

g. Mengatur posisi traktor untuk minching!

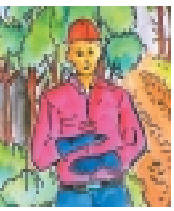

h. Pakai winch atas!

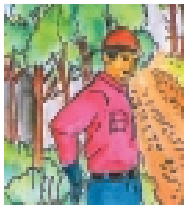

i. Masuk ke dalam traktor!

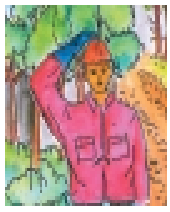

j. Traktor maju! 
- Pakailah penyaradan sistem "langsir" pada belokan tajam

Penyaradan sistem langsir diterapkan untuk mengurangi kerusakan pada tegakan tinggal dan tanah
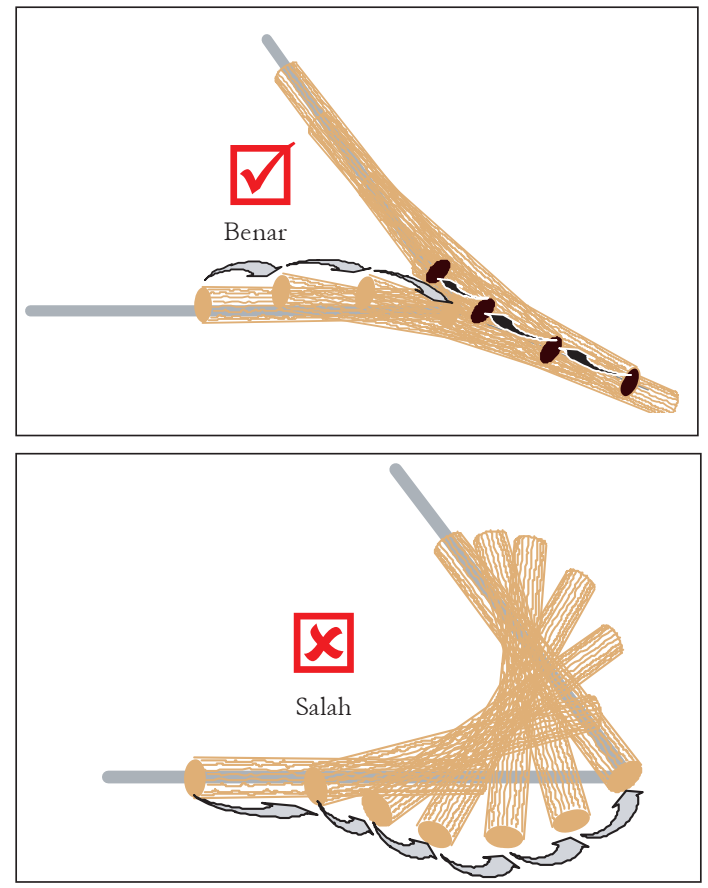


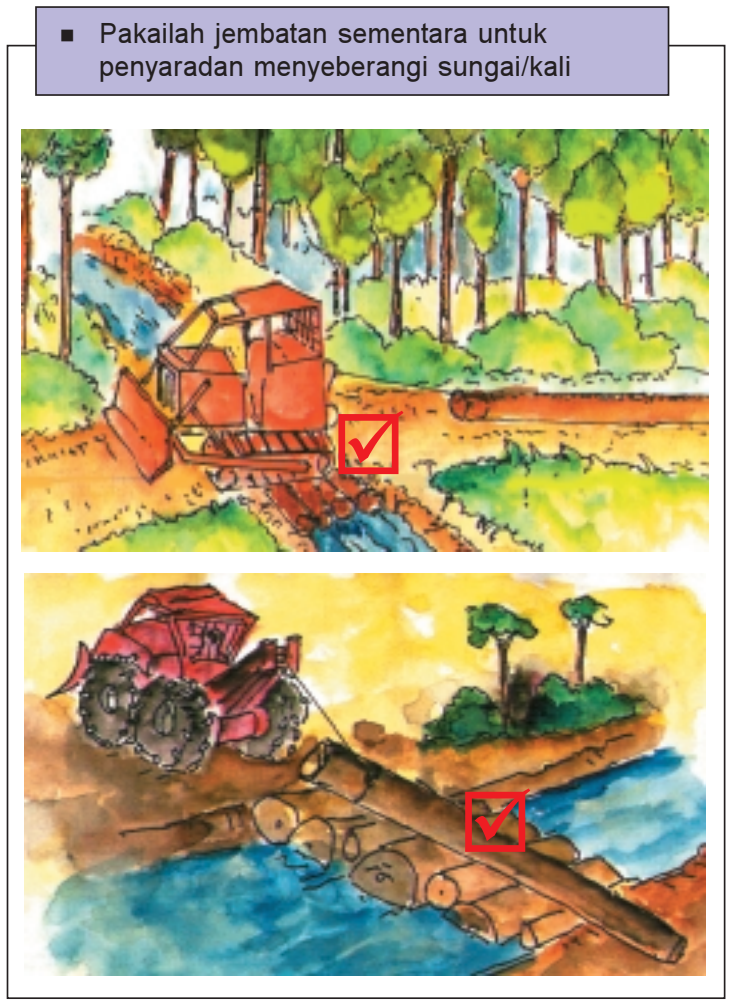




\section{Operasi di TPN}
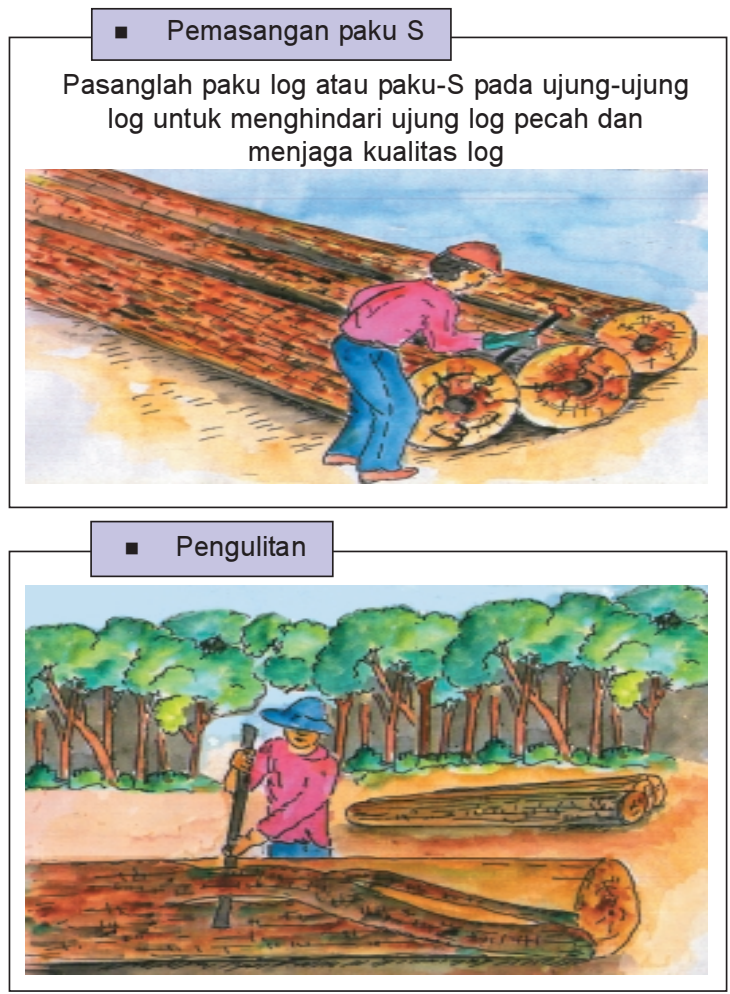


\section{Penumpukan kayu}

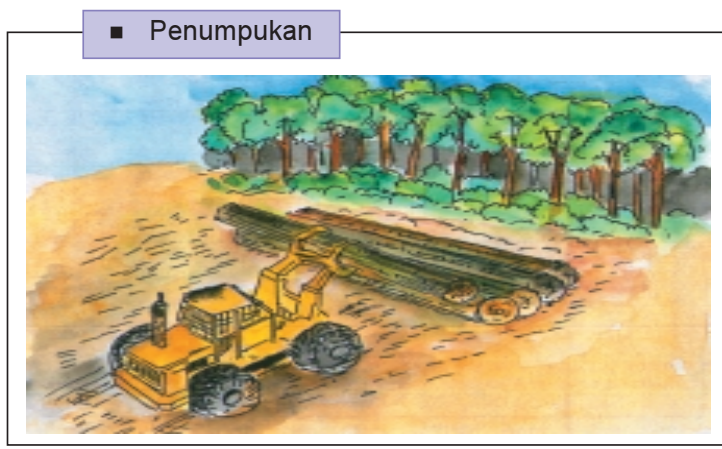

\section{Pemuatan}

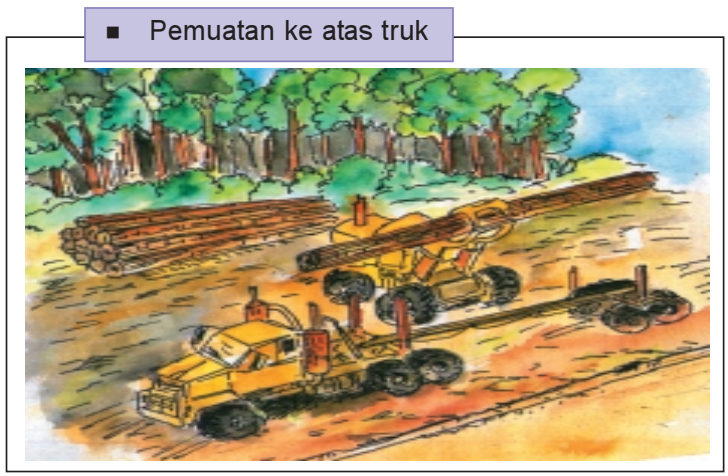




\section{PEMELIHARAAN, KESEHATAN KAMP DAN KESELAMATAN KERJA}

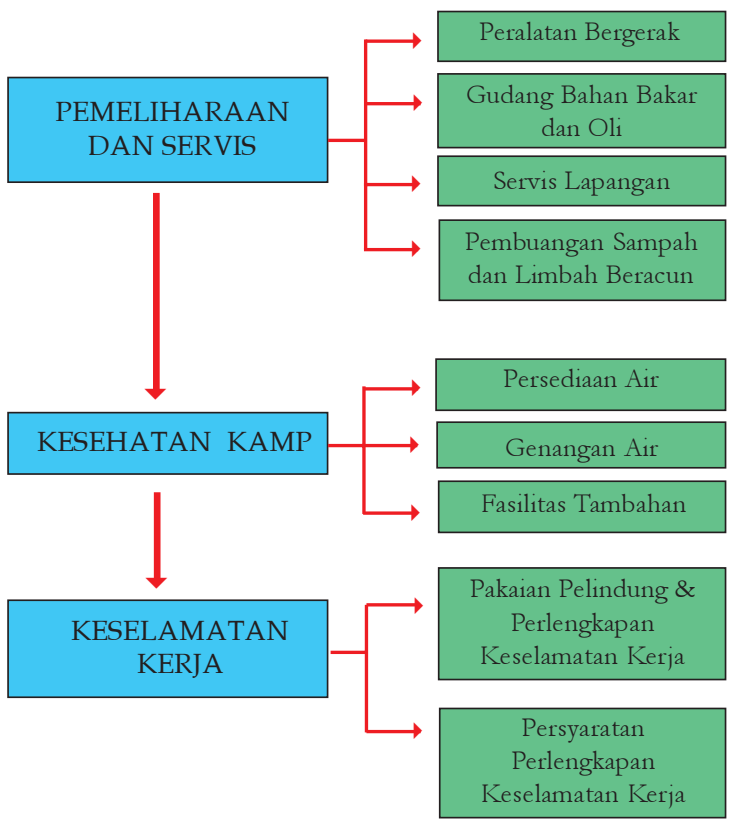




\section{PEMELIHARAAN DAN SERVIS}

\section{Peralatan Bergerak}

- Semua peralatan harus dibersihkan secara menyeluruh sebelum dipindahkan ke areal operasi yang baru

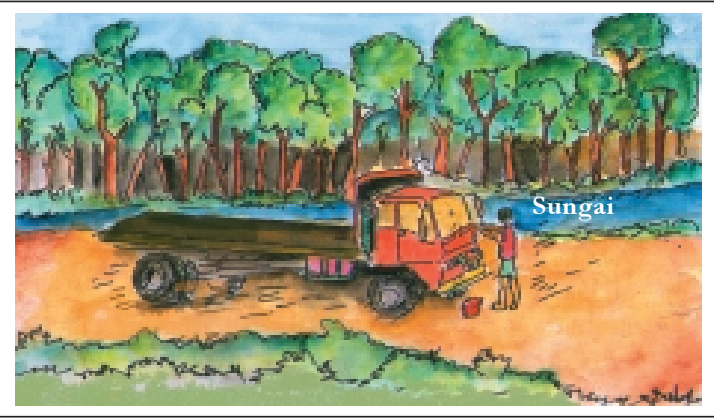




\section{Gudang Bahan Bakar dan Oli}

- Lokasi gudang bahan bakar dan oli harus di areal yang mempunyai drainase yang baik, terletak paling tidak $100 \mathrm{~m}$ dari desa dan $50 \mathrm{~m}$ dari sungai

- Bila gudang bahan bakar harus berlokasi di dermaga, maka :

* Harus diletakan jauh dari laut, selama penggunaan selang pompa masih memungkinkan

* Dilengkapi bangunan yang baik dan tahan bocor, bila terjadi tumpahan dapat dipompa ke tempat pembuangan sampah

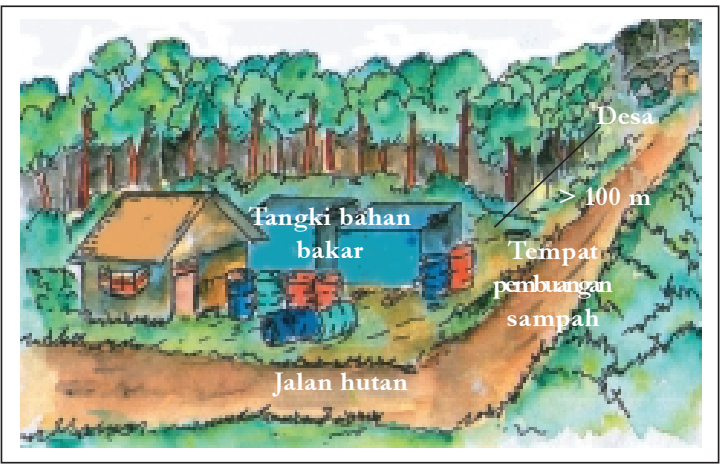




\section{Servis Lapangan dan Pemeliharaan}

- Tangki bahan bakar, tempat pengisian bahan bakar dan areal pemeliharaan kendaraan diletakkan :

* Di tempat yang drainasenya baik, di TPN atau di persimpangan jalan

* Di luar kawasan yang tidak ditebang

- Oli bekas tidak boleh dibuang di areal pemanenan kayu. Oli tersebut harus dikumpulkan dan dibuang ke tempat pembuangan utama

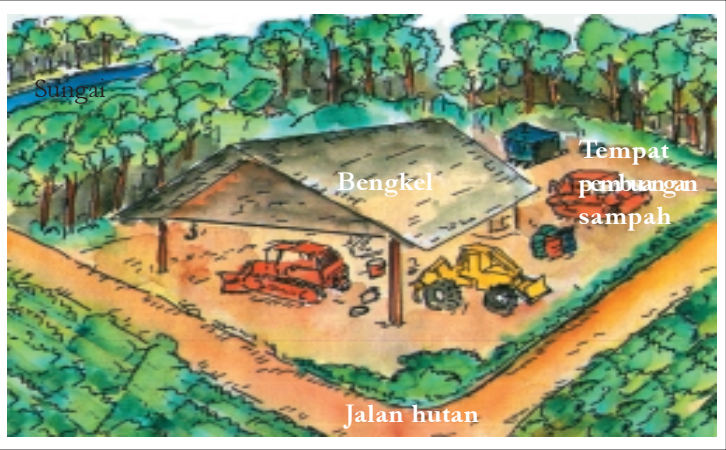




\section{Pembuangan Sampah dan Limbah Beracun}

- Tempat pembuangan sampah harus diletakkan setidaknya $100 \mathrm{~m}$ dari tinggi batas banjir maksimum dan setidaknya $1 \mathrm{~m}$ di atas tinggi air tanah maksimum

- Lokasi tempat pembuangan sampah harus diberi tanda yang jelas (termasuk tanda-tanda dalam bahasa daerah) dan lubang sampah harus dipagari

- Bahan-bahan beracun harus dikumpulkan dikontainer yang disegel

- Semua limbah padat harus dimasukkan ke dalam lubang sampah dan dipendam segera setelah pemanenan kayu di areal tersebut selesai

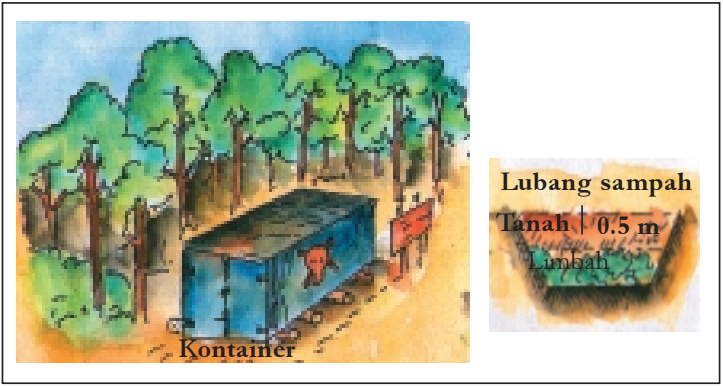



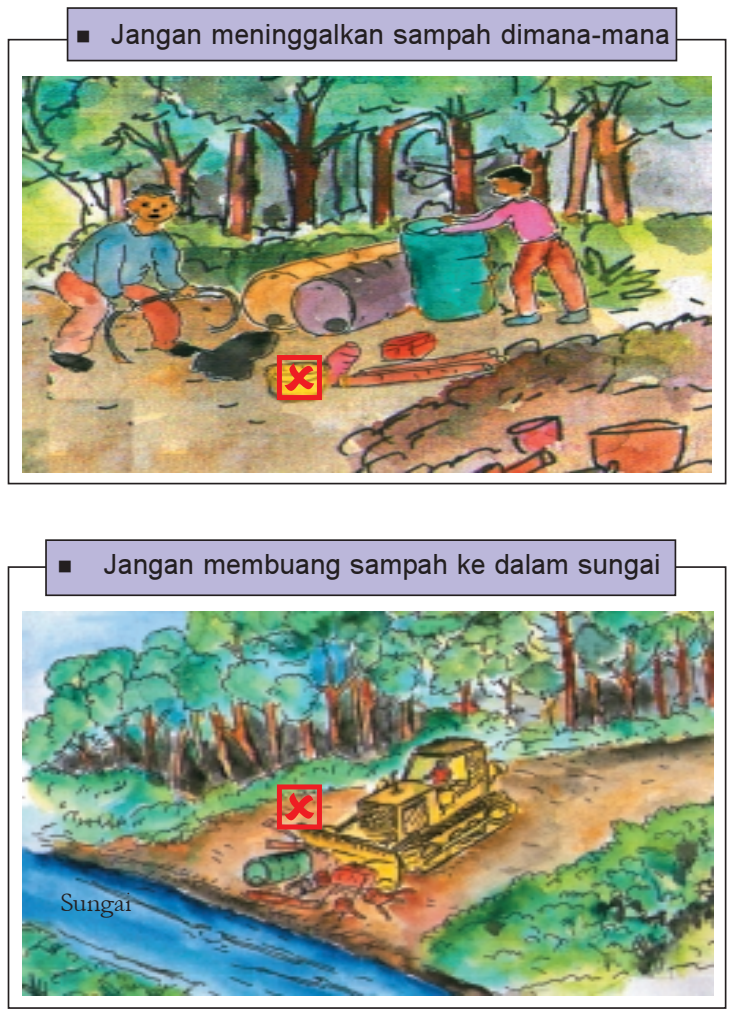


\section{KESEHATAN KAMP}

\section{Persediaan Air}

- Kamp-kamp harus disuplai dengan air bersih dari sungai yang mengalir, air hujan atau sumur

- Air disimpan dalam tangki dan penyimpanan air harus disaring dengan baik

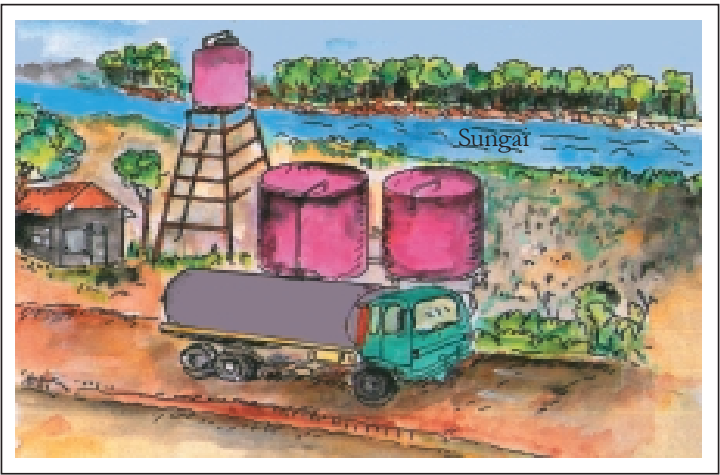




\section{Genangan Air}

- Areal kamp harus mempunyai drainase yang baik, sehingga air tidak menggenang dan menjadi tempat nyamuk bertelur/sarang nyamuk

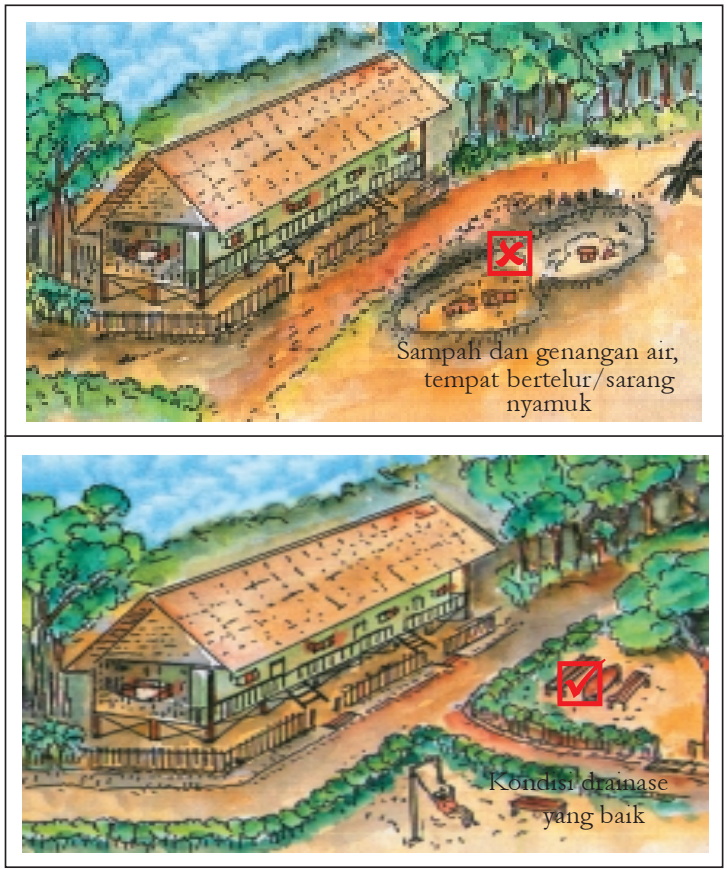




\section{Fasilitas Tambahan}

- Fasilitas tambahan kamp harus mencakup :

* Klinik kesehatan

* Sarana pendidikan

* Sarana rekreasi, dan

* Sarana peribadatan

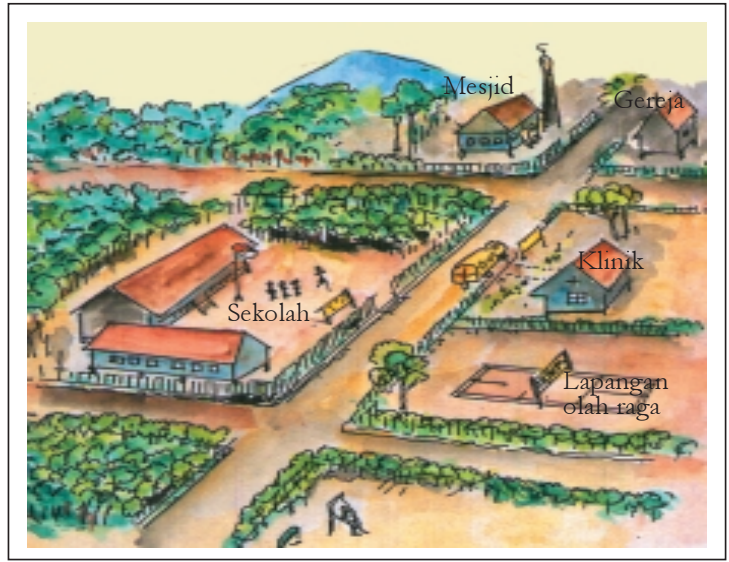




\section{KESELAMATAN KERJA}

\section{Pakaian Pelindung dan}

Perlengkapan Keselamatan Kerja

\section{Pedoman untuk pakaian pelindung}

\begin{tabular}{|l|c|c|c|c|c|c|c|c|}
\hline $\begin{array}{c}\text { Pekerja } \\
\text { Pemanenan }\end{array}$ & $\begin{array}{c}\text { Sepatu } \\
\text { Boot }\end{array}$ & $\begin{array}{c}\text { Celana } \\
\text { Pelindung }\end{array}$ & $\begin{array}{c}\text { Pakaian } \\
\text { yang } \\
\text { melekat }\end{array}$ & $\begin{array}{c}\text { Pakaian } \\
\text { yang mudah } \\
\text { dilihat }\end{array}$ & $\begin{array}{c}\text { Sarung } \\
\text { Tangan }\end{array}$ & $\begin{array}{c}\text { Pelindung } \\
\text { Kepala }\end{array}$ & $\begin{array}{c}\text { Penutup } \\
\text { muka }\end{array}$ & $\begin{array}{c}\text { Pelindung } \\
\text { telinga }\end{array}$ \\
\hline $\begin{array}{l}\text { Operator } \\
\text { Chainsaw }\end{array}$ & $\sqrt{ }$ & $\sqrt{ }$ & $\sqrt{ }$ & $\sqrt{ }$ & $\sqrt{ }$ & $\sqrt{ }$ & $\sqrt{ }$ & $\sqrt{ }$ \\
\hline $\begin{array}{l}\text { Operator } \\
\text { Traktor }\end{array}$ & $\sqrt{ }$ & & $\sqrt{ }$ & $\sqrt{ }$ & $\sqrt{ }$ & $\sqrt{ }$ & & $\sqrt{ }$ \\
\hline $\begin{array}{l}\text { Operator } \\
\text { Loader }\end{array}$ & $\sqrt{ }$ & & $\sqrt{ }$ & $\sqrt{ }$ & $\sqrt{ }$ & $\sqrt{ }$ & & $\sqrt{ }$ \\
\hline Helper & $\sqrt{ }$ & & $\sqrt{ }$ & $\sqrt{ }$ & $\sqrt{ }$ & $\sqrt{ }$ & $\sqrt{ }$ \\
\hline
\end{tabular}

\section{Persyaratan-persyaratan}

Perlengkapan Keselamatan Kerja

\section{Standar minimum keselamatan kerja}

\section{Chainsaw:}

- Tanda yang jelas pada tombol ON-OFF

- Pegangan pengaman

- Rem rantai dan penangkal rantai

- Sistem pembuangan yang menjauhkan asap dari operator

- Kotak Pertolongan Pertama Pada Kecelakaan (P3K) 

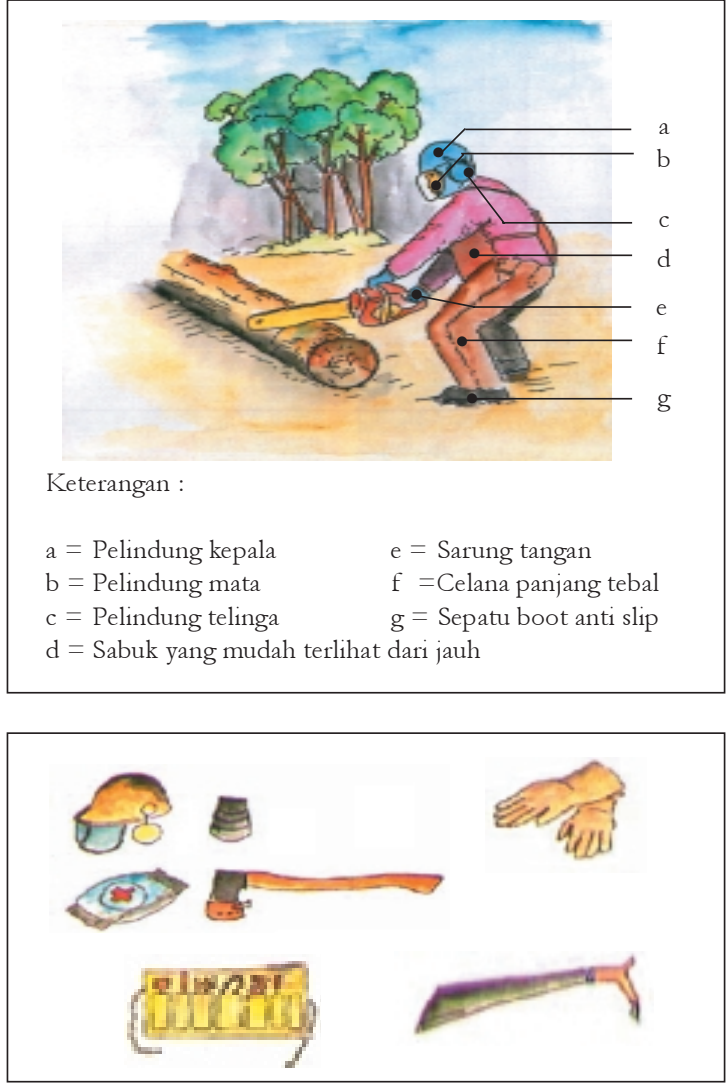
- Standar minimum keselamatan kerja

\section{Traktor :}

- Struktur pelindung menggelinding ("Roll Over Protection Structures/ROPS")

- Struktur pelindung kejatuhan benda ("Falling Object Protection Structure/FOPS")

- Tempat duduk dan sabuk pengaman

- Belakang tempat duduk atau kerangkanya dipasangi anyaman kawat pengaman

- Alarm kendaraan

- Pegangan pengaman penarik kipas, tali kipas, sabuk dan daun-daun kipas

- Positif, alat penghenti mesin yang tidak berputar balik

- Tabung pemadam kebakaran yang dipasang kuat dan mudah dilepas

- Sistem pembuangan yang dilengkapi dengan penangkap percikan api

- Kotak P3K 


\section{KEGIATAN PASCA PEMANENAN KAYU}

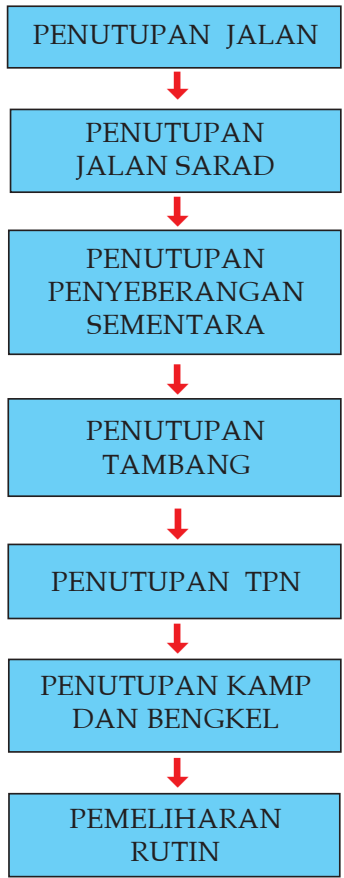




\section{PENUTUPAN JALAN}

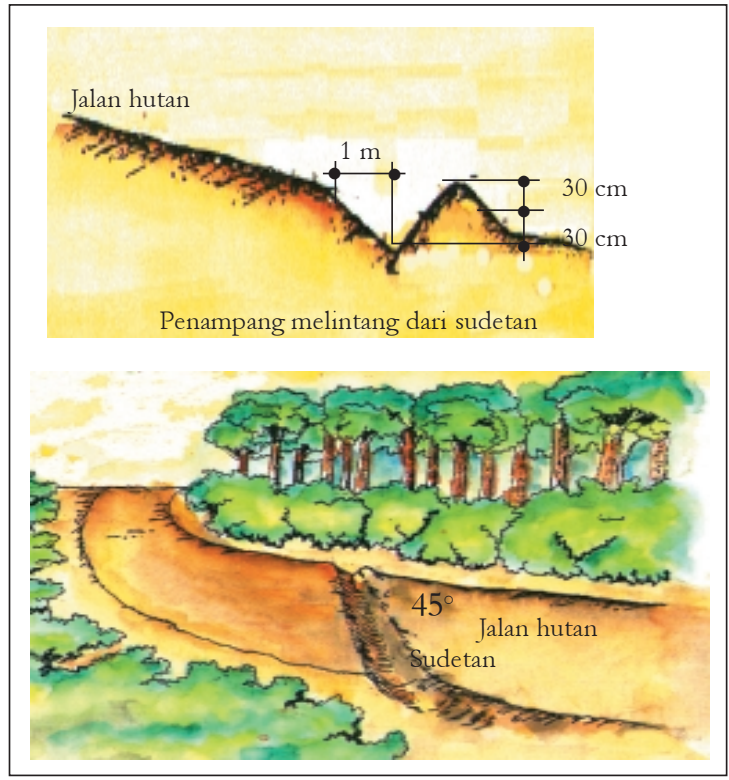




\section{PENUTUPAN JALAN SARAD}

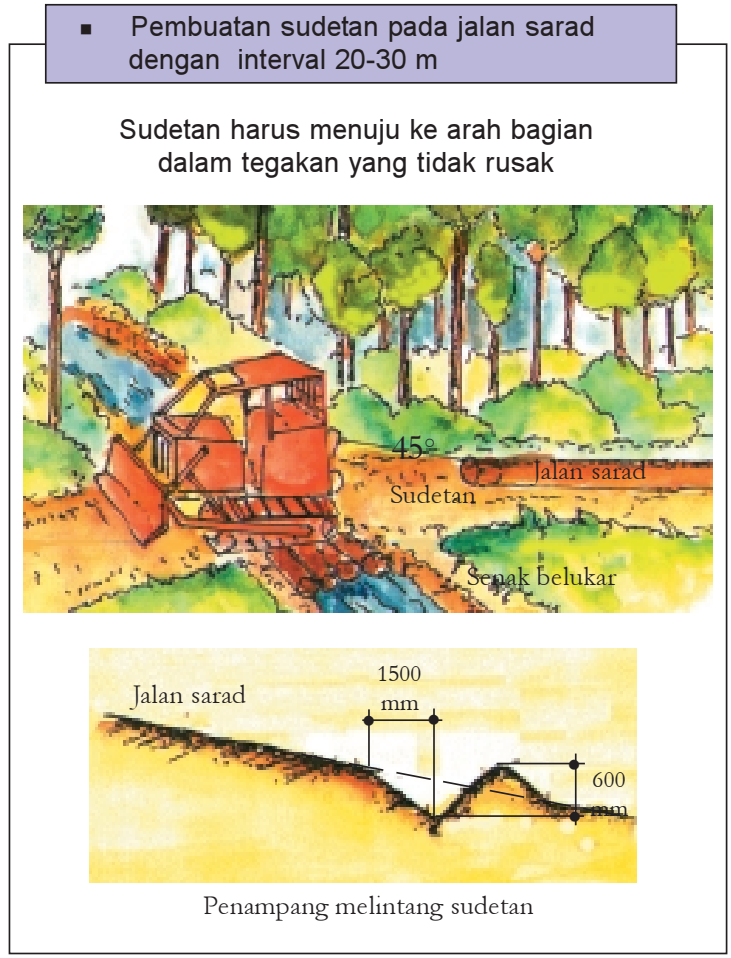




\section{PENUTUPAN PENYEBERANGAN SEMENTARA}

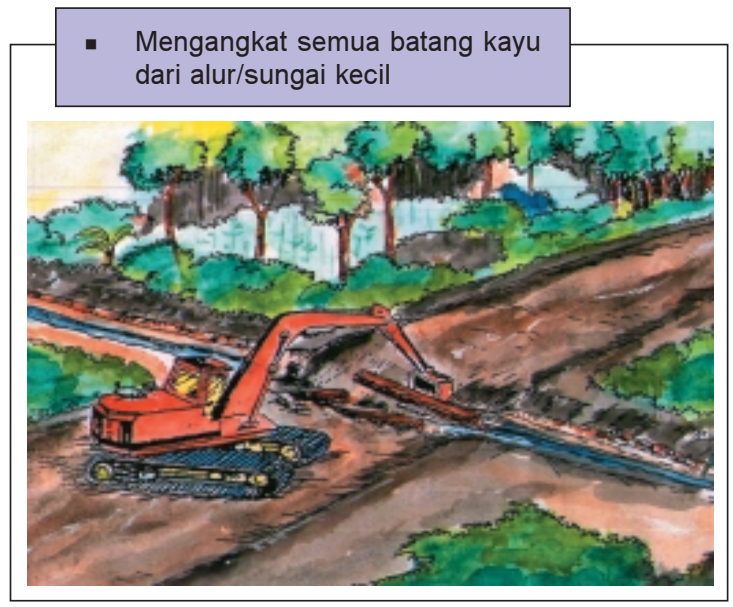



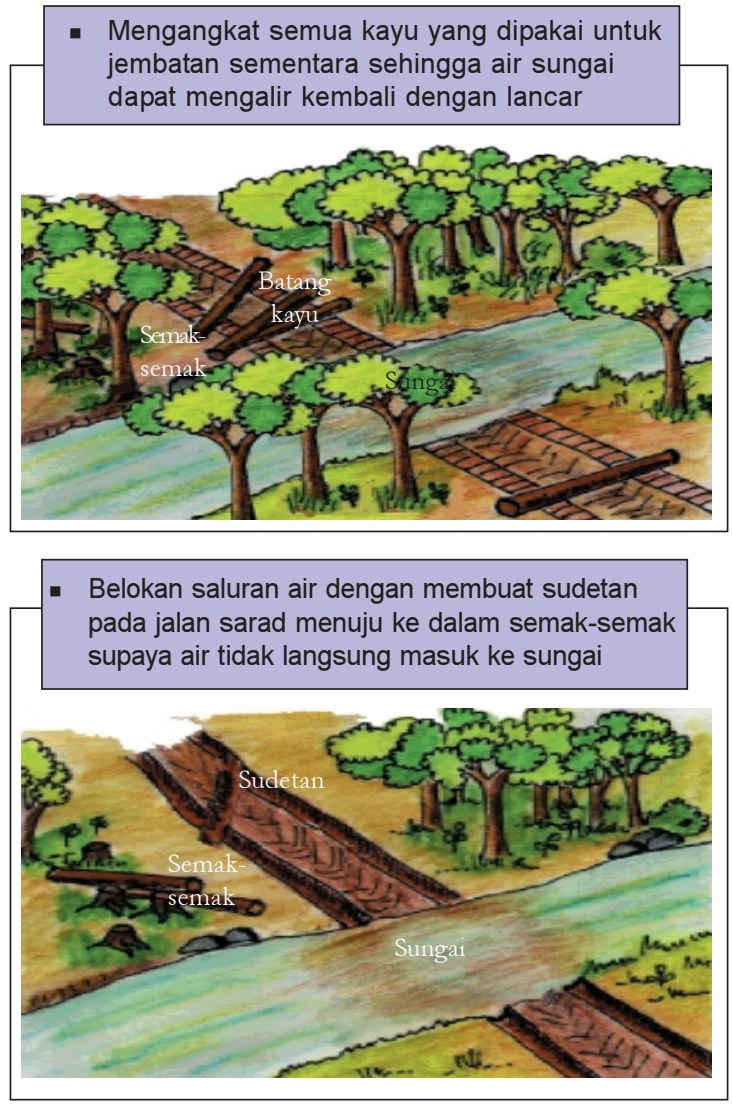


\section{PENUTUPAN TAMBANG BATU (QUARRY)}
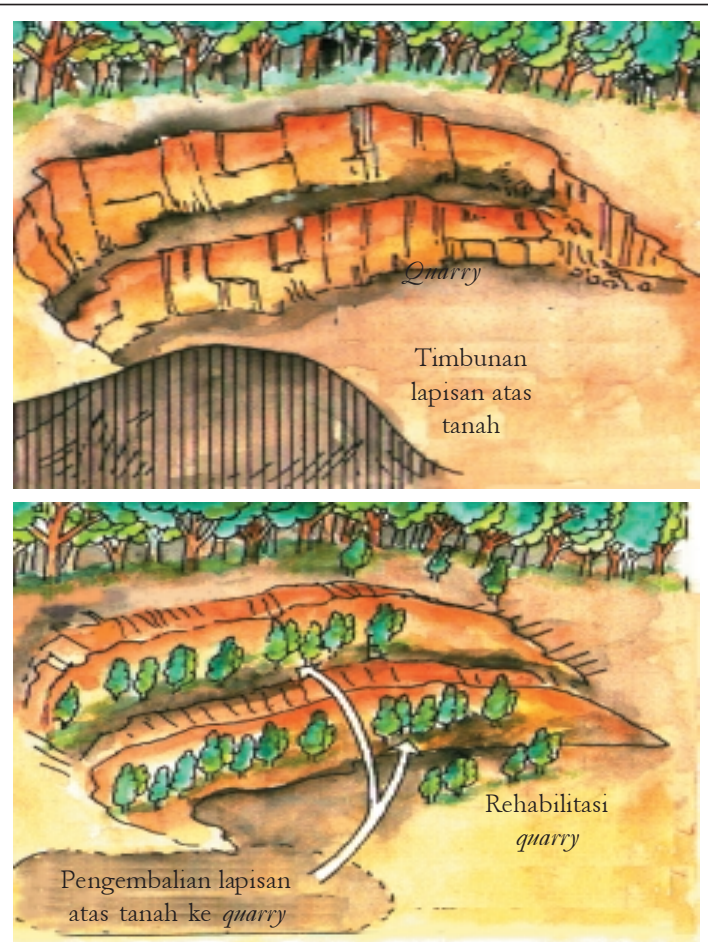


\section{PENUTUPAN TPN}
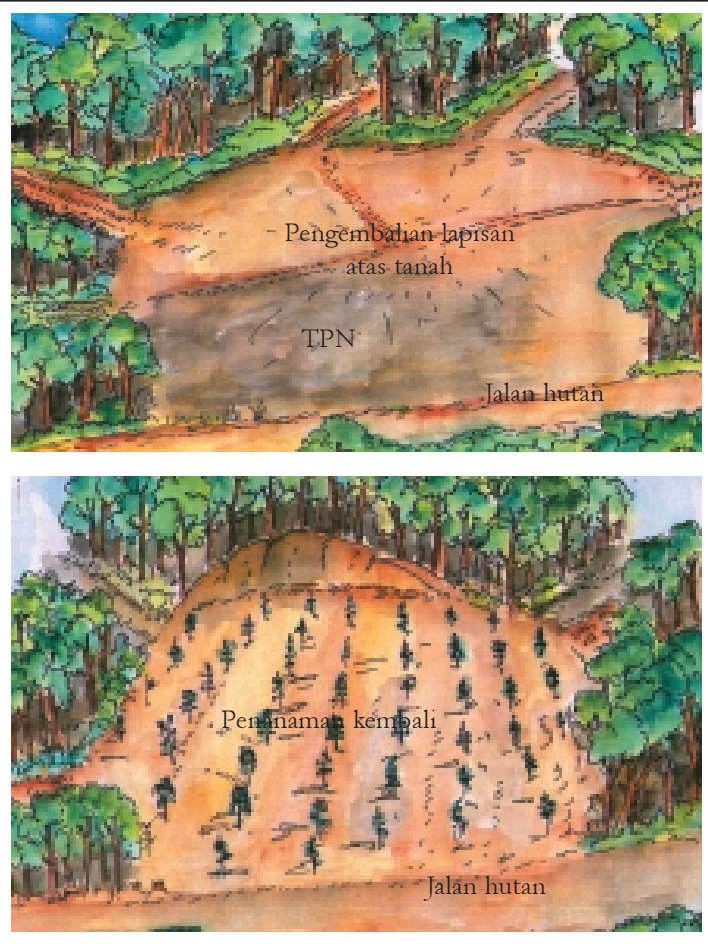


\section{PENUTUPAN KAMP DAN BENGKEL}

- Bersihkan semua sampah di areal kamp dan bengkel

- Semua limbah padat harus dimasukan ke dalam lubang sampah dan ditimbun dengan tanah

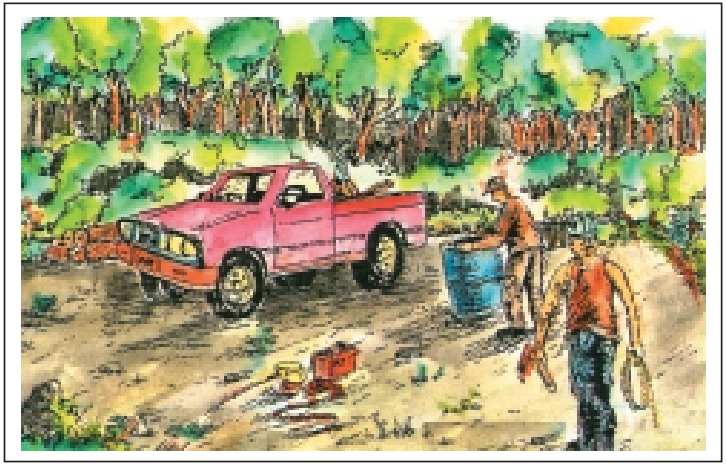




\section{PEMELIHARAAN RUTIN}
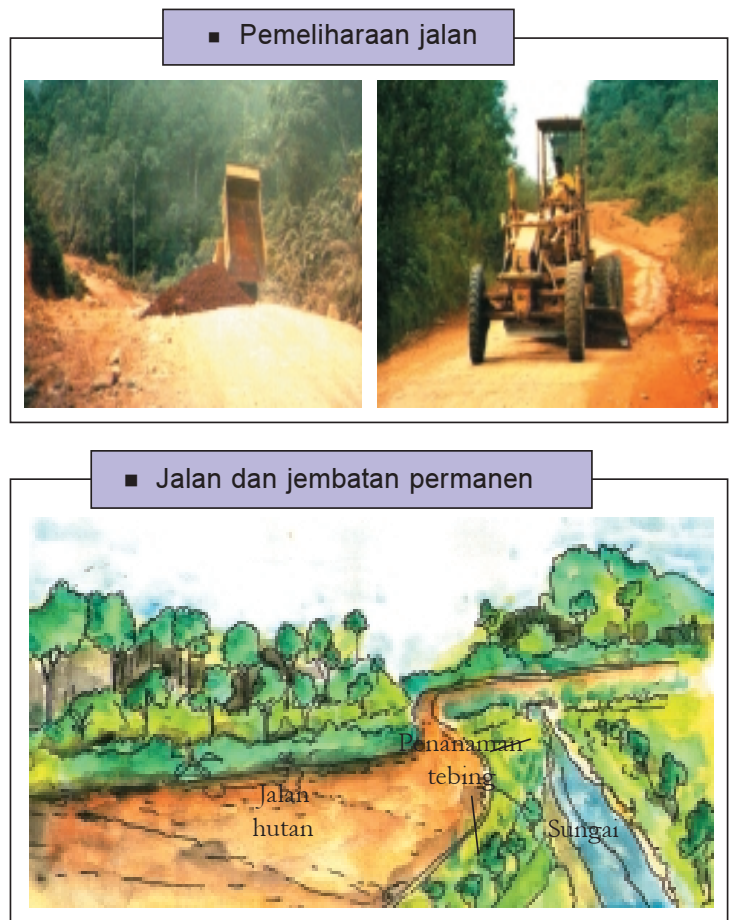


\section{- Pemeliharaan drainase jalan}

- Semua jalan harus diratakan secara teratur

- Tambahan perlengkapan konstruksi seperti roller dan watercart diperlukan bersama grader untuk memadatkan tanah

- Pemeliharaan jalan memerlukan tambahan material permukaan jalan secara periodik

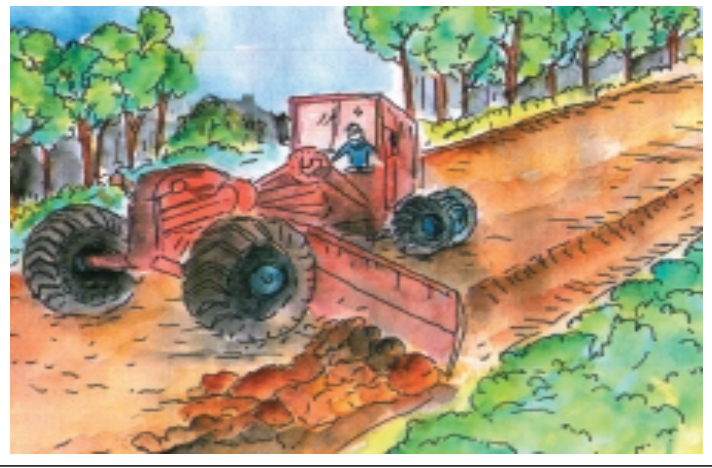




\section{- Pemeliharaan jembatan}

- Jembatan-jembatan harus di inspeksi paling kurang dua kali tiap tahun, untuk memastikan:

* Sungai dalam keadaan bersih dari sampah

* Struktur jembatan tetap stabil

* Tembok/dinding sayap pelindung berfungsi dengan baik dan tidak terjadi erosi

* Tidak terjadi pengikisan pada pondasi jembatan

* Permukaan penutup jembatan dalam keadaan baik

* Jembatan dapat dilewati dengan mudah

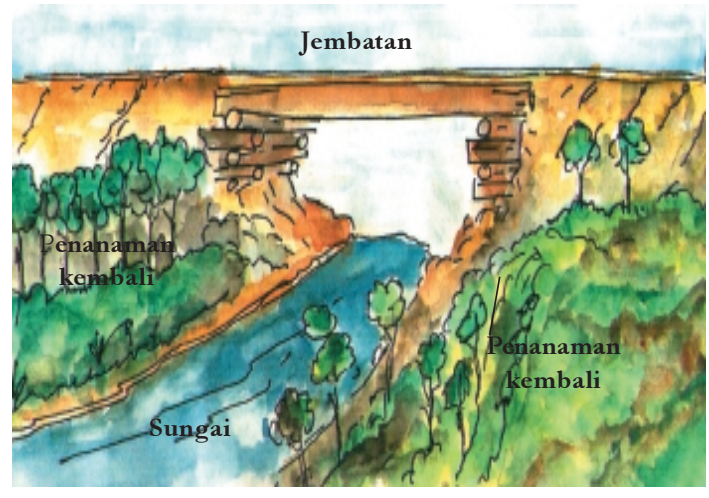


- Pemeliharaan gorong-gorong

- Gorong-gorong harus diinspeksi dan dipelihara secara teratur

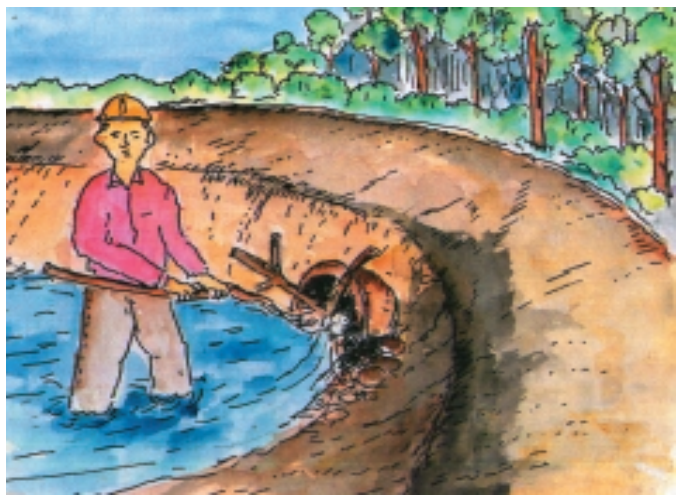




\section{DAFTAR PUSTAKA}

Departemen Kehutanan, RI. 1993. Pedoman dan Petunjuk Teknis Tebang Pilih Tanam Indonesia (TPTI) pada Hutan Alam Daratan. Departemen Kehutanan, Direktorat Jenderal Pengusahaan Hutan, Jakarta, Indonesia.

Elias. 1997. Pembukaan Wilayah Hutan. Fakultas Kehutanan IPB, Bogor, Indonesia.

FAO. undated. A Manual for Planning, Design and Construction of Forest Roads in Steep Terrain. FAO, Rome, Italy.

Ruslim, Y. 1998. Petunjuk Dasar dalam Timber Cruising dan Survei Topografi. SFMP Document No. 16(1998). Promotion of Sustainable Forest Management Systems (SFMP) in East Kalimanta.

TFF and APHI. 2001. Prosedur Survey Topografi Hutan. Tropical Forest Foundation bekerjasama dengan Asosiasi Pengusaha Hutan Indonesia, Indonesia 


\section{TAMBAHAN BAHAN BACAAN \\ YANG DISARANKAN}

Asia-Pacific Forest Commission. 1999. Code of Practice for Harvesting in Asia-Pacific. RAP Publication 1999/ 12, Bangkok, Thailand.

Departemen Kehutanan, RI dan APHI. 1997. Buku Petunjuk

Penggunaan Program "Forest Inventory-End Product Lingking Programme" (FIEPLP). Modul Pelatihan di Wanariset Semboja, Kalimantan Timur, Indonesia.

Department of Forests, Vanuatu. 1997. Vanuatu Reduced Impact Logging Guidelines. December, 1997. Vanuatu.

Department of Forestry and Wildlife, Kingdom of Cambodia. 1999. The Cambodian Code of Practice for Forest Harvesting. Cambodia.

Department of Foresty and Estate Crops, RI and NRM Program Foresty Office. 2000. Principles and Practices for Forest Harvesting in Indonesia. Indonesia.

Elias. 1999. Buku Saku Reduced Impact Logging. PT. Penebar Swadaya, Jakarta, Indonesia.

Elias. 1999. Reduced Impact Timber Harvesting in the Indonesian Selective Cutting and Planting System. IPB Press, Bogor, Indonesia.

Elias. 1998. Reduced Impact Timber Harvesting in the Tropical Natural Forest in Indonesia. FAO, Rome, Italy.

FAO. 1998. Guidelines for Management of Tropical Forests. Rome, Italy.

Klasson,B. undated. Felling Guidelines for Reduced Impact Logging in Tropical Moist Forest. unpublished report. 
Kusmaryono, B., J.R. Watulangkow dan H. Prayudi. 1997. Petunjuk Pengukuran Lapangan "Forest Inventory-End Product Linking Programme' (FIEPLP). Modul Pelatihan di Wanariset Semboja, Kalimantan Timur, Indonesia, Juni 1997.

Sist, P., Dykstra, D.P., Fimbel, R. 1998. Ground-Based Reduced-Impact Logging Guidelines for Lowland and Hill Dipterocarp Forests in Indonesia. CIFOR, Occacional Paper, No. 15. 